\title{
THE ATTRACTIVENESS OF 66 COUNTRIES FOR INSTITUTIONAL REAL ESTATE INVESTMENTS: A COMPOSITE INDEX APPROACH
}

\author{
Karsten Lieser \\ Alexander Peter Groh
}


The CIIF, International Center for Financial Research, is an interdisciplinary center with an international outlook and a focus on teaching and research in finance. It was created at the beginning of 1992 to channel the financial research interests of a multidisciplinary group of professors at IESE Business School and has established itself as a nucleus of study within the School's activities.

Ten years on, our chief objectives remain the same:

- Find answers to the questions that confront the owners and managers of finance companies and the financial directors of all kinds of companies in the performance of their duties

- Develop new tools for financial management

- Study in depth the changes that occur in the market and their effects on the financial dimension of business activity

All of these activities are programmed and carried out with the support of our sponsoring companies. Apart from providing vital financial assistance, our sponsors also help to define the Center's research projects, ensuring their practical relevance.

The companies in question, to which we reiterate our thanks, are:

Aena, A.T. Kearney, Caja Madrid, Fundación Ramón Areces, Grupo Endesa, Royal Bank of Scotland and Unión Fenosa.

http://www.iese.edu/ciif/ 


\title{
THE ATTRACTIVENESS OF 66 COUNTRIES FOR INSTITUTIONAL REAL ESTATE INVESTMENTS: A COMPOSITE INDEX APPROACH
}

\author{
Karsten Lieser ${ }^{1}$ \\ Alexander Peter Groh ${ }^{2}$
}

\begin{abstract}
We address the attractiveness of 66 countries worldwide for institutional real estate investments through the construction of a composite index. For the index's composition, we refer to the results of prior research on the parameters determining real estate investment activity on an aggregated country level. Our index reveals a country ranking that correlates reasonably with commercial real estate investments, as proven with back-tests over six years. We increase the transparency of market variables for decision-making in global real estate asset allocation and provide the key determinants that shape national real estate markets. The results highlight the strengths and weaknesses of developed, transition and emerging economies and provide guidelines for political improvements to attract international capital to spur real estate investment activity.
\end{abstract}

JEL Classification: G11, G23, G24, 016, 018, P25, P52

Keywords: Real Estate Investments, International Asset Allocation, Real Estate Market Attractiveness

\footnotetext{
${ }^{1}$ Research Affiliate of the International Centre of Financial Research, IESE Business School, (klieser@iese.edu)

${ }^{2}$ Associate Professor of Finance, EM Lyon Business School, (groh@em-lyon.com)
} 


\section{THE ATTRACTIVENESS OF 66 COUNTRIES FOR INSTITUTIONAL REAL ESTATE INVESTMENTS: A COMPOSITE INDEX APPROACH}

\section{Introduction}

Institutional investors in international commercial real estate have one key objective: to perform transactions with satisfying risk and return ratios. They look globally to achieve their goals, and set their sights on emerging regions in many cases, attracted by high growth expectations and diversification prospects. In fact, a substantial number of investors have exposure to foreign markets either by direct investments or through intermediaries. Especially for investors in countries with a limited real estate market size, international investing becomes a necessity (Worzala, 1994).

However, building an international real estate portfolio often means venturing into the unknown, where one meets unfamiliar political, legal and economic environments, difficulties in finding deal partners, and potentially illiquid exit markets alongside different cultures and languages. Although the expected economic growth and advantages of diversification opportunities might appear attractive, the risk of investing in emerging regions must not be neglected. Prior research submits that commercial real estate exists in countries within a broad institutional context defined by sound economic growth, prevailing depth and liquid capital markets, and a stable political and socio-economic structure. Further, each country's real estate market is conditioned, amongst other criteria, by administrative and regulatory burdens, and by the legal protection of investors. Clearly, these institutional characteristics vary strongly over countries and regions, and gradually over time. However, the differences are important for the analysis of long-term perspectives in institutional investors' asset allocation processes (Worzala, 1994; Worzala and Newell, 1997; Geurts and Jaffe, 1996; D’Arcy and Keogh, 1998, 1999; Lim, McGreal, and Webb, 2006; Chin, Dent, and Roberts, 2006; Falkenbach, 2009).

In this paper, we address the international real estate allocation process and propose a composite measure to compare the attractiveness of 66 countries worldwide. We review the literature and search for criteria which determine both supply and demand for commercial real estate investments in a country. We find 66 data series as proxies for these criteria, aggregate them to the "Global Real Estate Investment Attractiveness Index (Global REIA Index)" and receive a country attractiveness ranking. Via sensitivity analyses, we show that our index is robust with respect to different weighting and aggregation methods and correlates reasonably with commercial real estate investments. We furthermore compare the tracking power of our index with related measures proposed in prior literature and by practitioners. The index structure allows for benchmarking, and we comment on our results, pointing to the strengths and weaknesses of developed, transition and emerging markets. 


\section{Literature Review}

Related research focuses on the determinants of commercial real estate activity in national economies or regional markets based on empirical, survey or conceptual analyses. We group the literature overview into six sub-chapters that reflect the structure of our index, as we will subsequently explain. Each heading represents one of six "key drivers," which we view as important, appropriate and quantifiable for determining a country's attractiveness for institutional real estate investments.

\subsection{Economic Activity}

It is intuitive that real estate investment performance is related to the general economic activity and prosperity of a region or country. According to DiPasquale and Wheaton's model (1992), a productive economy positively affects the demand for real estate assets. Chin, Dent, and Roberts (2006) conclude from survey data that a sound economic structure and an expected strong and stable economy are perceived to be the most significant factors in a region's ability to attract foreign real estate investments. Hoskins, Higgins, and Cardew (2004) find that GDP growth, inflation and unemployment show significant relations with composite property returns. Chen and Hobbs (2003) find that the size of a country's economy positively affects investment activity, as larger economies are usually more capable of withstanding external economic turmoil and are therefore more stable than smaller economies. Van Doorn (2003) notes that GDP per capita is commonly used in strategic real estate asset allocation for determining a country's economic level of development. Connor and Liang (2000) argue that, over the long term, the impact of technology on real estate has been overwhelmingly positive. As technological advances have increased productivity and wealth, demand for all types of real estate has also increased.

\subsection{Real Estate Investment Opportunities}

Han (1996) concludes from his survey that real estate investment opportunities, demographic attributes, and the market structure are important selection criteria for investment decisions. The accessibility of institutional real estate via different ownership ratios is a critical factor in real estate investment due to the close relationship between market entry probability, liquidity risk, and transparency of markets. Liang and Gordon (2003) estimate the availability of higher quality, not owner-occupied commercial real estate in a theoretical model. Kurzrock et al. (2007) finds via cross-sectional regression that a high degree of agglomeration has a positive impact on property performance. Obviously, accelerating urbanization, which determines the structure, potential and quality of the real estate environment, plays an important role in the investment decision. This is especially valid for the United States, where urban areas are spreading across major regions, pushing up land and building values, and making real estate assets increasingly valuable. Lynn (2007) notes, that improvement in communication and transportation infrastructure facilitates the migration to cities and drives the pace of urbanization, which will support new development. Furthermore, the financial and business service sectors reflect a growing level of sophistication in the service economy and thus, the demand for commercial real estate. 


\subsection{Depth and Sophistication of the Capital Market}

Mueller (1995) argues that the physical real estate market, with its capital-intensive nature, depends on general international capital flows. Adair et al. (1999) and Adlington et al. (2008) find that viable and sustainable real estate markets require an established liquid capital market, including a stable banking and financial services system. Connor and Liang (2000) argue that public sources of equity capital, primarily as REITs, are particularly important for a dynamic real estate investment activity due to the potential for securitizing financial claims and raising capital on the public market at relatively low cost. Additionally, FDI (foreign direct investment) inflow into a country plays an important role in the state of the real estate investment environment. Laposa and Lizieri (2005) show that FDI relaxation for investments in retail businesses has given further impetus to the commercial real estate sector. Even so, since commercial real estate assets are often used as collateral within leveraged buyout transactions, Roulac (1996a) notes that private equity investors play an active role in flourishing real estate markets.

\subsection{Investor Protection and Legal Framework}

Sound legal structures and the protection of property rights influence the attractiveness of countries for any kind of investment activity. Chin, Dent, and Roberts (2006) and Lim, McGreal, and Webb (2006) find via surveys that particular aspects of the legal framework and legal regulation are very sensitive for real estate investors' market perceptions. They relate this finding to the immobility of real estate property and to the complexity of real estate transactions. La Porta et al. $(1997,1998)$ confirm that the legal environment strongly determines the size and extent of a country's capital market and local companies' ability to receive outside financing. They emphasize the difference between law on books and the quality of law enforcement. La Porta et al. (1997) argue that, of the world's four legal systems (English, French, German and Scandinavian), the English common law system is the most suitable for enhancing capital market development, while the French system is the least attractive. Glaeser et al. (2001), and Djankov et al. (2003, 2005) suggest that parties in common-law countries have greater ease in enforcing their rights arising from commercial contracts. Even so, Knack and Keefer (1995), Mauro (1995), and Svensson (1998) demonstrate that property rights significantly affect investments and economic growth.

\subsection{Administrative Burdens and Regulatory Limitations}

D'Arcy and Keogh (1998) claim that each country's real estate market is conditioned, amongst other things, by landlord and tenant law, planning law, and urban policy. The burden of doing real estate business and taxation are considered to directly affect the operational efficiencies of any kind of business. Worzala (1994) and Adair et al. (1999) note that this significantly affects foreign investors at three times: when investing, operating or exiting a market. McGreal, Parsa, and Keivani (2001) argue that regulatory limitations, exchange controls and the repatriation of capital restrain international capital flows and, hence, are a major source of concern for investors.

\subsection{Socio-cultural and Political Environment}

Keogh and D'Arcy (1999) argue that countries' national property markets are defined by their socio-cultural and political environment. The socio-political risk comprises social risk and 
government policy risk and is an indicator of institutional problems in a country's public sector. Lim, McGreal, and Webb (2006) as well as Chin, Dent, and Roberts (2006) found political stability to be the most important factor underpinning international investors' country choices when entering emerging or transition economies. Solnik (1999) confirms that the political risks of foreign investment lower the expected success of international diversification, as even with low risks, the associated potential loss may be large. Lee (2001) notes that the level of perceived crime and corruption faced by business within a country can prove to be a major impediment to the successful implementation of an investment strategy. Geurts and Jaffe (1996) argue that a country's socio-cultural framework is closely related to its political environment, influencing the overall investment climate.

\subsection{Summary of the Literature Review}

The numerous contributions emphasize the difficulty of identifying the appropriate criteria for our index. There is no consensus about the most important criteria, no weighting nor any ranking which includes all the factors mentioned in the literature.

Indeed, while some of the criteria are discussed more comprehensively, and certainly, bear considerable significance, it remains unclear how these criteria interact in combination with a real estate market's investment activity. For example, it is difficult to predict whether the real estate market activity in a country with a high investor protection level is more affected by the liquidity of the national stock market or by regulatory limitations. While the influence of some factors (such as the possibility of utilizing the public capital market) is not necessary linked to any specific location (because REITs can be issued and placed abroad), other factors such as socio-cultural and political instabilities or legal issues cannot be evaded.

For calculating the index, it would be ideal to include all the criteria mentioned. However, some of the papers cited focus on particular economies or regions, depending on the data available. Their datasets usually do not cover more countries, and are not really comparable with datasets that provide a broader scope. We try to find the best possible proxies for the drivers identified of commercial real estate investment activity, and likewise aim to keep the country coverage at a maximum. Therefore, we summarize the related literature under our sub-chapter headings, and identify six main criteria that ultimately determine a country's attractiveness for real estate investments: Economic Activity, Real Estate Investment Opportunities, Depth and Sophistication of its Capital Market, Investor Protection and Legal Framework, Administrative Burdens and Regulatory Limitations, Socio-cultural and Political Environment. We consider these parameters to be "key drivers," and base our index structure on them.

Since none of the key drivers are directly measurable, we regard them as latent constructs and search for data series that adequately express their character. If data series share a common character with respect to their socio-economic sense, we group them in sub-constructs. Overall, we find 66 individual data series grouped into 31 sub-constructs to describe the six latent key drivers and obtain a framework of factors as presented in Table 1. 


\section{Table 1}

Conceptual Framework of Real Estate Investment Attractiveness

\begin{tabular}{|c|c|c|c|c|c|}
\hline 1 Economic Activity & $\begin{array}{l}2 \text { Real Estate } \\
\text { Investment } \\
\text { Opportunities }\end{array}$ & $\begin{array}{l}3 \text { Depth and } \\
\text { Sophistication of } \\
\text { Capital Market }\end{array}$ & $\begin{array}{l}4 \text { Investor Protection } \\
\text { and Legal Framework }\end{array}$ & $\begin{array}{l}5 \text { Administrative } \\
\text { Burdens and } \\
\text { Regulatory } \\
\text { Limitations }\end{array}$ & $\begin{array}{l}6 \text { Socio-cultural and } \\
\text { Political Environment }\end{array}$ \\
\hline $\begin{array}{l}\text { 1.1 GDP Size } \\
(+)\end{array}$ & $\begin{array}{c}2.1 \text { Institutional } \\
\text { Property Estimation } \\
(+)\end{array}$ & $\begin{array}{l}\text { 3.1 Stock Market } \\
\text { Liquidity (+) }\end{array}$ & $\begin{array}{l}4.1 \text { Investor } \\
\text { Protection (+) }\end{array}$ & $\begin{array}{l}\text { 5.1 Taxation \& Capital } \\
\text { Gains Taxation (-) }\end{array}$ & $\begin{array}{l}6.1 \text { Human } \\
\text { Development } \\
\text { Indicator }(+)\end{array}$ \\
\hline $\begin{array}{c}\text { 1.2 GDP per Capita } \\
(+)\end{array}$ & $\begin{array}{l}2.2 \text { Degree of } \\
\text { Urbanisation (+) }\end{array}$ & $\begin{array}{l}\text { 3.2 IPO Market } \\
\text { Activity (+) }\end{array}$ & $\begin{array}{c}4.2 \text { Security of } \\
\text { Property Rights (+) }\end{array}$ & $\begin{array}{l}\text { 5.2 Ease of Getting a } \\
\text { Construction Permit } \\
\qquad(+)\end{array}$ & 6.2 Crime (-) \\
\hline $\begin{array}{c}\text { 1.3 GDP Growth } \\
(+)\end{array}$ & $\begin{array}{c}2.3 \text { Urban Population } \\
\text { \& Growth (+) }\end{array}$ & $\begin{array}{l}\text { 3.3 M\&A Market } \\
\text { Activity (+) }\end{array}$ & $\begin{array}{l}\text { 4.3 Quality of Legal } \\
\text { Enforcement (+) }\end{array}$ & $\begin{array}{c}\text { 5.3 Ease of } \\
\text { Registering Property } \\
(+)\end{array}$ & $\begin{array}{l}6.3 \text { Bribing \& } \\
\text { Corruption (-) }\end{array}$ \\
\hline $\begin{array}{l}\text { 1.4 Working Force } \\
\qquad(+)\end{array}$ & $\begin{array}{l}\text { 2.4 Quality of } \\
\text { Infrastructure (+) }\end{array}$ & $\begin{array}{l}\text { 3.4 Debt \& Credit } \\
\text { Market (+) }\end{array}$ & $\begin{array}{l}\text { 4.4 Regulatory Quality } \\
(+)\end{array}$ & $\begin{array}{l}\text { 5.4 Ease of Starting a } \\
\text { Business }(+)\end{array}$ & $\begin{array}{l}\text { 6.4 Political System } \\
(+)\end{array}$ \\
\hline $\begin{array}{c}1.5 \text { Inflation } \\
(-)\end{array}$ & $\begin{array}{l}\text { 2.5 Development of } \\
\text { Service Sector (+) }\end{array}$ & $\begin{array}{c}3.5 \text { Access to Private } \\
\text { Capital }(+)\end{array}$ & & $\begin{array}{c}\text { 5.5 Ease of Closing a } \\
\text { Business (+) }\end{array}$ & \\
\hline $\begin{array}{c}1.6 \text { Innovation } \\
(+)\end{array}$ & & 3.6 REIT Market (+) & & $\begin{array}{l}\text { 5.6 Foreign Exchange } \\
\text { Controls (-) }\end{array}$ & \\
\hline
\end{tabular}

Positive/negative sign according to the impact on real estate investment activity.

We refer to the sub-constructs as the lower index level (or level 2) and aggregate the individual data series and the constructs to concentrate information on the level of the key drivers. The final step is to aggregate the six key drivers to the overall index.

An important issue is the determination of the weights of the individual data series, constructs and key drivers when aggregating the index. We describe the structure of the constructs, the methodologies for determining the weights and aggregating the index in the following section.

\section{Construction of the Global REIA Index}

\subsection{Data Sample}

The first step in constructing the index is to specify appropriate data series and the sample of countries to be included. Our selection of data series is based on the findings of previous literature. The task is to find adequate measures which share common characteristics with one of the six key drivers identified for a large country sample, while the country sample is only determined by the availability of these data series. We deliberately attempt to include as many countries as possible, and present the sample in Table 2. 


\section{Table 2}

Country Sample

Region Country Sample $(\mathrm{N}=66)$

\begin{tabular}{|c|c|c|c|c|}
\hline $\begin{array}{l}\text { Africa } \\
(\mathrm{N}=4)\end{array}$ & Kenya & Morocco & Nigeria & South Africa \\
\hline $\begin{array}{l}\text { Asia } \\
(\mathrm{N}=13)\end{array}$ & $\begin{array}{l}\text { China } \\
\text { Japan } \\
\text { Russian Federation } \\
\text { Vietnam }\end{array}$ & $\begin{array}{l}\text { Hong Kong } \\
\text { Malaysia } \\
\text { Singapore }\end{array}$ & $\begin{array}{l}\text { India } \\
\text { Philippines } \\
\text { Taiwan }\end{array}$ & $\begin{array}{l}\text { Indonesia } \\
\text { Republic of Korea } \\
\text { Thailand }\end{array}$ \\
\hline $\begin{array}{l}\text { Australasia } \\
(\mathrm{N}=2)\end{array}$ & Australia & New Zealand & & \\
\hline $\begin{array}{l}\text { Eastern Europe } \\
(\mathrm{N}=13)\end{array}$ & $\begin{array}{l}\text { Bulgaria } \\
\text { Hungary } \\
\text { Romania } \\
\text { Ukraine }\end{array}$ & $\begin{array}{l}\text { Croatia } \\
\text { Latvia } \\
\text { Slovakia }\end{array}$ & $\begin{array}{l}\text { Czech Republic } \\
\text { Lithuania } \\
\text { Slovenia }\end{array}$ & $\begin{array}{l}\text { Estonia } \\
\text { Poland } \\
\text { Turkey }\end{array}$ \\
\hline $\begin{array}{l}\text { Latin America } \\
(\mathrm{N}=9)\end{array}$ & $\begin{array}{l}\text { Argentina } \\
\text { Mexico } \\
\text { Venezuela }\end{array}$ & $\begin{array}{l}\text { Brazil } \\
\text { Paraguay }\end{array}$ & $\begin{array}{l}\text { Chile } \\
\text { Peru }\end{array}$ & $\begin{array}{l}\text { Colombia } \\
\text { Uruguay }\end{array}$ \\
\hline $\begin{array}{l}\text { Middle East } \\
(\mathrm{N}=6)\end{array}$ & $\begin{array}{l}\text { Egypt } \\
\text { Saudi Arabia }\end{array}$ & $\begin{array}{l}\text { Israel } \\
\text { UAE }\end{array}$ & Kuwait & Oman \\
\hline $\begin{array}{l}\text { North America } \\
(\mathrm{N}=2)\end{array}$ & Canada & United States & & \\
\hline $\begin{array}{l}\text { Western Europe } \\
(\mathrm{N}=17)\end{array}$ & $\begin{array}{l}\text { Austria } \\
\text { France } \\
\text { Italy } \\
\text { Portugal } \\
\text { United Kingdom }\end{array}$ & $\begin{array}{l}\text { Belgium } \\
\text { Germany } \\
\text { Luxembourg } \\
\text { Spain }\end{array}$ & $\begin{array}{l}\text { Denmark } \\
\text { Greece } \\
\text { Netherlands } \\
\text { Sweden }\end{array}$ & $\begin{array}{l}\text { Finland } \\
\text { Ireland } \\
\text { Norway } \\
\text { Switzerland }\end{array}$ \\
\hline
\end{tabular}

The regions are defined by their geographical and socio-economic affiliation.

Our aim is to use publicly available and commonly accepted data sets to achieve reproducible and unbiased results. We gathered more than 300 data series for different country samples and present below in Table 3 our final selection of 66 individual raw data series that allow coverage of the countries presented in Table 2. However, the selection remains arguable: we might include additional data series, or exchange some of them for alternative series. Or we could have included too many individual items for the calculation, thereby over-determining the index. It could be more appropriate to use fewer items to predict a country's real estate market attractiveness. However, in this paper, our intention is to provide a framework and methodology for constructing a composite measure like ours and leave optimization of the index's structure to future research.

Table 3 shows the selected raw data series, their units and sources (or alternative sources if data were not available for all countries) that we have used to calculate our index. The outline in Table 3 also represents the index structure. The six first-order constructs correspond to the six key drivers already defined. The criteria of all lower orders are grouped and aggregated to the next superior construct to finally proxy the six latent drivers. 


\section{Table 3}

Raw Data Sample and Sources

\begin{tabular}{|c|c|c|c|}
\hline \# & Name & Unit & Source \\
\hline 1. & \multicolumn{3}{|l|}{ Economic Activity } \\
\hline 1.1. & Economic Size & [LN USD mn] & Euromonitor International \\
\hline 1.2. & GDP per capita & [‘000 USD per capita] & Euromonitor International \\
\hline 1.3. & Real GDP Growth (3 yrs average) & {$[\%]$} & Euromonitor International \\
\hline 1.4. & Unemployment rate & {$[\%]$} & Euromonitor International \\
\hline 1.5. & $\begin{array}{l}\text { Inflation, Average Consumer } \\
\text { Prices }\end{array}$ & {$[\%]$} & International Monetary Fund \\
\hline 1.6. & General Innovativeness Index & {$[-]$} & INSEAD \\
\hline 2. & \multicolumn{3}{|c|}{ Real Estate Investment Opportunities } \\
\hline $\begin{array}{l}2.1 . \\
2.2 .\end{array}$ & $\begin{array}{l}\text { Institutional Property Estimation } \\
\text { Degree of Urbanization }\end{array}$ & [LN USD mn] & Euromonitor International \\
\hline 2.2.1. & Agglomeration Poles & [number] & United Nations \\
\hline 2.2.2. & Housing stock & [LN ‘000] & Euromonitor International \\
\hline 2.3. & Urban Population & & \\
\hline 2.3.1. & Urban Population & [\% of Population] & Euromonitor International \\
\hline 2.3.2. & Urban Population Growth & {$[\%]$} & Euromonitor International \\
\hline 2.4 & Quality of Infrastructure & & \\
\hline 2.4.1. & Density of road network & [km per sq km of land] & Euromonitor International \\
\hline 2.4.2. & Quality of road infrastructure & {$[-]$} & World Economic Forum 2008-2009 \\
\hline 2.4.3. & Quality of railroad infrastructure & {$[-]$} & World Economic Forum 2008-2009 \\
\hline 2.4.4. & $\begin{array}{l}\text { Quality of air transport } \\
\text { infrastructure }\end{array}$ & {$[-]$} & World Economic Forum 2008-2009 \\
\hline 2.4.5. & Quality of electricity supply & {$[-]$} & World Economic Forum 2008-2009 \\
\hline 2.4.6. & Telecommunication & [per capita] & World Development Indicators \\
\hline $\begin{array}{l}2.5 . \\
3 .\end{array}$ & $\begin{array}{l}\text { Services Total Output } \\
\text { Depth of Capital Market }\end{array}$ & {$[\%$ of GDP] } & World Development Indicators \\
\hline 3.1. & $\begin{array}{l}\text { Size and Liquidity of the Stock } \\
\text { Market }\end{array}$ & & \\
\hline 3.1.1. & Stock Market Capitalization & [LN USD mn] & Euromonitor International \\
\hline 3.1.2. & Total Trading Volume & {$[\%$ of GDP] } & World Bank (WDI) \\
\hline 3.2 . & IPO Market Activity & & \\
\hline 3.2.1. & IPO Market Volume & [LN USD mn] & Thomson One Banker \\
\hline 3.2.2. & Number of IPOs & [LN ‘000] & Thomson One Banker \\
\hline 3.3. & M\&A Market Activity & & \\
\hline 3.3.1. & M\&A Market Volume & [LN USD mn] & Thomson One Banker \\
\hline 3.3.2. & Number of Deals & [LN'000] & Thomson One Banker \\
\hline 3.4 . & Debt \& Credit Market & & \\
\hline 3.4.1. & $\begin{array}{l}\text { Domestic Credit provided by } \\
\text { Banking Sector }\end{array}$ & [\% of GDP] & World Bank (WDI) \\
\hline 3.4.2. & Ease of Access to Loans & {$[-]$} & World Economic Forum \\
\hline 3.4.3. & Credit Information Index & {$[-]$} & $\begin{array}{l}\text { World Bank (Doing Business } \\
\text { Database) }\end{array}$ \\
\hline 3.4.4. & Soundness of Banks & {$[-]$} & World Economic Forum \\
\hline 3.4.5. & Interest Rate Spread & {$[\%]$} & World Economic Forum \\
\hline 3.4.6. & $\begin{array}{l}\text { Bank Non-performing Loans to } \\
\text { Total Gross Loans }\end{array}$ & {$[\%]$} & World Bank (WDI) \\
\hline 3.5. & Access to Private Capital & & \\
\hline 3.5.1. & $\begin{array}{l}\text { Foreign Direct Investment, Net } \\
\text { Inflows }\end{array}$ & [LN USD mn] & Euromonitor International \\
\hline 3.5.2. & Private Equity Investments & [LN USD mn] & Thomson One Banker \\
\hline 3.6. & REITs Market Volume & [LN USD mn] & FTSE EPRA NAREIT Series \\
\hline
\end{tabular}


4. Investor Protection and Legal Framework

4.1. Investor Protection

4.1.1. Disclosure Index

$[-]$

$[-]$

$[-]$

4.1.3. Shareholder Suits Index

4.2. Security of Property Rights

4.2.1. Legal Rights Index

4.2.2. Property Rights

4.3. Quality of Legal Enforcement

4.3.1. Judicial Independence

4.3.2. Integrity of the Legal System

4.3.3. Rule of Law

4.4. Regulatory Quality

5. Administrative Burdens and Regulatory Limitations

5.1. Taxation

5.1.1. Marginal Corporate Tax Rate

5.1.2. Profit and Capital Gains Tax

5.2. Burden Getting a Construction Permit

5.2.1. Costs

5.2.2. Number of Procedures

5.2.3. Duration

5.3. Ease of Registering Property

5.3.1. Costs (incl. Transfer Taxes)

5.3.2. Number of Procedures

5.3.3. Duration

5.4. Ease of Starting a Business

5.4.1. Number of Procedures to start a [\#] Business

5.4.2. Time needed to start a Business

5.4.3. Cost of Business Start-Up Procedures

5.4.4. Min. Capital

5.5. Ease of Closing a Business

5.5.1. Time [Years]

$\begin{array}{ll}\text { 5.5.2. } & \text { Cost } \\ \text { 5.5.3. Recovery Rate [Cents on US } \$ \text { ] }\end{array}$

5.6. Foreign Exchange Controls

[\%]

$[\%]$

$[-]$

[\% of income per

capita]

[number]

[days]

[\% of property value] [number]

[days]

[Days]

[\% of Income per

Capita]

[\% of Income per

Capita]

[\% of Estate]

[Cents on USD]

[-]
World Bank (Doing Business)

World Bank (Doing Business)

World Bank (Doing Business)

World Bank (Doing Business)

Heritage Foundation

Fraser Institute

Fraser Institute, PRS Group

World Bank (WGI)

World Bank (WGI)

\section{Socio-cultural and Political Environment}

\begin{tabular}{|c|c|c|c|}
\hline $\begin{array}{l}6.1 . \\
6.2 .\end{array}$ & $\begin{array}{l}\text { Human Development } \\
\text { Crime }\end{array}$ & {$[-]$} & Euromonitor International \\
\hline 6.2.1. & $\begin{array}{l}\text { Business Costs of Crime and } \\
\text { Violence }\end{array}$ & {$[-]$} & World Economic Forum \\
\hline $\begin{array}{l}6.2 .2 . \\
6.3 .\end{array}$ & $\begin{array}{l}\text { Costs of Organized Crime } \\
\text { Bribery \& Corruption }\end{array}$ & {$[-]$} & World Economic Forum \\
\hline 6.3.1. & Bribery \& Corruption Index & {$[-]$} & Transparency International \\
\hline 6.3.2. & Control of Corruption & {$[-]$} & World Bank (WGI) \\
\hline 6.4 & Political System & & \\
\hline 6.4.1. & Voice and Accountability & {$[-]$} & World Bank (WGI) \\
\hline 6.4.2. & $\begin{array}{l}\text { Political Stability and Absence of } \\
\text { Violence }\end{array}$ & {$[-]$} & World Bank (WGI) \\
\hline 6.4.3. & Government Effectiveness & {$[-]$} & World Bank (WGI) \\
\hline
\end{tabular}

Readymade indices without any unit are indicated with [-].

World Bank (WDI)

World Bank (WDI)

World Bank (Doing Business)

World Bank (Doing Business)

World Bank (Doing Business)

World Bank (Doing Business)

World Bank (Doing Business)

World Bank (Doing Business)

World Bank (Doing Business)

World Bank (Doing Business)

World Bank (Doing Business)

World Bank (Doing Business)

World Bank (Doing Business)

World Bank (Doing Business)

World Bank (Doing Business) World Bank (Doing Business)

World Bank (Doing Business)

Heritage Foundation

Euromonitor International

World Economic Forum

World Economic Forum

Transparency International

World Bank (WGI)

World Bank (WGI) 
We collect time series ranging from 2000 to 2009 and usually refer to the latest data record. For growth data, for example, real GDP growth, we calculate the three-year geometric mean in order to smooth fluctuations and capture the medium-term trends. For some of the data series, we apply the logarithmic transformation to control for skewness of the cross-sectional data. In less than $2 \%$ of all cases, data were not available for a certain year. If data points are missing, we apply the three methods suggested by Nardo et al. (2005a), in the following order: a) We try to find missing data in other databases or via the Internet; b) we interpolate between adjacent data records, and c) we use the latest available data.

However, we do not always use raw data but sometimes refer to ready-made indices like the "doing business indices" from the World Bank. ${ }^{1}$ For detailed descriptions of the individual index items, we refer the reader to this paper's Appendix and the original data sources, where comprehensive definitions and descriptions of the data series are provided.

\subsection{Composition of the Index}

In general, composite indicators are used to summarize a number of underlying individual indicators or variables. They are quantitative or qualitative measures derived from a series of observed facts that can reveal or proxy characteristics and serve as information for specific decisions. In general, we follow the approach proposed by Nicoletti et al. (2000).

We determine a structure of three sub-index levels and group the items according to their socio-economic interpretation. The main advantage of this structure is that we can trace back indicator values to increasing levels of detail. This will help in interpreting the strengths and weaknesses of individual countries and in drawing up the conclusions. We perform reliability analyses, using Cronbach's Alpha at raw data level to ascertain the consistency of the chosen data and our model's structure, and we rescale all data according to the linear rescaling method from 100 (best) to 1 (worst).

Using in principle this composition technique for all the calculations, we differentiate two methods to determine the weights for the overall index aggregation. The first method is simple, in that we weight equally the individual data series or constructs when we aggregate them on the superior index level. We refer to this as our base-case scenario. In the second approach, we perform factor analysis and discard data series from constructs, when the data do not meet the statistical requirements for running a proper factor analysis. The decision to include or discard data series from the index depends on the Kaiser-Meyer-Olkin Measure of Sampling Adequacy and the results of Bartlett's Test of Sphericity. Both methods are commonly used to prove consistency of the data series chosen and the validity of the factor analysis.

All the different weighting schemes are sensitive to the normalization and standardization of the underlying variables. Hence, we perform sensitivity analyses to analyze the impact of the different approaches on the results. Furthermore, we compare our index with alternative composite indices found in academic literature or regularly used in practice. All these procedures are described in the subsequent sections.

\footnotetext{
${ }^{1}$ See http://www.doingbusiness.org.
} 


\subsubsection{Analysis of Index Consistency}

Before modeling a composite index, it must be checked whether the data's underlying structure is appropriate for describing a uni-dimensional construct and whether the groups of indicators identified provide a good interpretation of the results. We use Cronbach's (1951) Alpha, which is the most common measure of internal consistency of the items in a model or a survey. ${ }^{2}$ It assesses how well a set of items measures uni-dimensionality. Cronbach's Alpha is defined as:

$$
\alpha=\frac{n \bar{R}}{1+(n-1) \bar{R}}
$$

where $n$ is the number of components of a (sub-) construct and $\bar{R}$ is the items' mean correlation (e.g. the mean of the non-diagonal terms of the correlation matrix). The coefficient increases with the number of sub-indicators and with the correlation of each tuple. Cronbach's Alpha is equal to zero if no correlation exists, i.e., if the sub-indicators are independent. The coefficient is equal to one if the sub-indicators are perfectly correlated. Hence, a high alpha indicates that the underlying items proxy well the desired characteristic. Nunnally (1978) suggests a value of 0.7 as an acceptable threshold. In our case, the Cronbach Alphas provide information if the selected data are adequate for expressing the six key drivers, and if it is appropriate to aggregate the six key drivers to the overall index. Table 4 presents the consistency of the six key drivers measured by their Cronbach Alphas.

\section{Table 4}

Consistency Analysis of the Raw Data on Key Driver and Index Level

\begin{tabular}{lll} 
& N & Cronbach Alpha \\
\hline 1. Economic Activity & 6 & 0.541 \\
\hline 2. Real Estate Investment Opportunities & 12 & 0.789 \\
\hline 3. Depth of Capital Market & 15 & 0.904 \\
\hline 4. Investor Protection and Legal Framework & 9 & 0.869 \\
\hline 5. Administrative Burdens and Regulatory Limitations & 16 & 0.802 \\
\hline 6. Socio-cultural and Political Environment & 8 & 0.952 \\
\hline Real Estate Investment Index & 66 & 0.965
\end{tabular}

All results stem from the rescaled raw data, which were grouped according to their socio-economic significance.

The analysis confirms that the composition of the key drivers and the overall index is statistically robust as signaled by the generally very high Cronbach Alphas. Unfortunately, Cronbach's Alpha for economic activity is below the cut-off value of 0.7. It could be improved to 0.792 by omitting GDP growth from our data sample. This recommendation results from a low correlation of GDP growth with the other data series used to assess the key driver economic activity, as the emerging countries predominantly show high economic growth rates but score

\footnotetext{
${ }^{2}$ Cf. Raykov (1998), Cortina (1993), Feldt et al. (1987), Green et al. (1977), Hattie (1985), and Miller (1995).
} 
low in some of the other indicators. However, we have decided not to exclude economic growth from our list of index items because literature proposes it as a very important real estate investment determinant and should motivate much of the real estate activity, especially in emerging countries. The Cronbach Alpha for the entire index is sufficiently high with 0.965 and leads us to continue with our pre-defined index structure. Overall, we propose that the selection of index items altogether is adequate for calculating a country's attractiveness for real estate investors, and use the index structure with the 66 data series as described above.

\subsubsection{Normalization Techniques}

All variables need to be normalized before they are aggregated into composite indicators. Various techniques exist for the normalization process, each one implying specific advantages and disadvantages. The most common normalization methods are briefly described below: ${ }^{3}$

Ranking is the simplest normalization technique and is not affected by outliers. This method allows us to follow the changes in countries' ranking positions over time. Nevertheless, as it only determines the absolute levels, the information on each underlying item and the distances between countries will be lost. ${ }^{4}$ The Ranking method is defined as: ${ }^{5}$

$$
I_{q c}^{t}=\operatorname{Rank}\left(x_{q c}^{t}\right)
$$

Standardization (or z-scores) converts the underlying data to a common scale of the standard normal distribution. Hence, data series with extreme values have a greater effect on the summarized indicator. This might be desirable if the intention is to reward exceptional behavior. The z-score formula is defined as: ${ }^{6}$

$$
I_{q c}^{t}=\frac{x_{q c}^{t}-x_{q c=\bar{c}}^{t}}{\sigma_{q c=\bar{c}}^{t}}
$$

The Re-scaling method is used to normalize indicators to an identical range by linear transformation. This method is vulnerable to extreme values or outliers, which can distort the transformation line due to a marginal change of the slope. Re-scaling can widen the range of indicators lying within a small interval, increasing the effect on the composite indicator above that of the z-scores transformation. The re-scaling method is expressed as: ${ }^{7}$

$$
I_{q c}^{t}=\frac{x_{q c}^{t}-\min _{c}\left(x_{q}^{t_{0}}\right)}{\max _{c}\left(x_{q}^{t_{0}}\right)-\min _{c}\left(x_{q}^{t_{0}}\right)}
$$

\footnotetext{
${ }^{3}$ Cf. Freudenberg (2003); Jacobs et al. (2004).

${ }^{4}$ Cf. Nardo et al. (2005a), p. 46.

${ }^{5}$ Note: $x_{i c}^{t}$ is the value of the indicator for country c at time t. $\bar{c}$ is the reference country.

${ }^{6}$ Cf. Nardo et al. (2005a), p. 20.

${ }^{7}$ Cf. Nardo et al. (2005a), p. 20.
} 
The distance to a reference measures a given indicator's relative position to a reference point. The reference point can be an external benchmark country, or any aimed target. This method is defined by the following formula: ${ }^{8}$

$$
I_{q c}^{t}=\frac{x_{q c}^{t}}{x_{q c=\bar{c}}^{t_{0}}} \quad \text { or } \quad I_{q c}^{t}=\frac{x_{q c}^{t}-x_{q c=\bar{c}}^{t_{0}}}{x_{q c=\bar{c}}^{t_{0}}}
$$

Alternatively, the reference country could be the sample's average country. While other countries would receive scores depending on their distance relative to the average, the score of one would be given to the benchmark. Hence, an item score above one indicates above-average performance. Overall, this normalization method is simple and not affected by outliers. However, the arbitrariness of the chosen threshold level and the omission of absolute level information are usually criticized.

In addition, there are cyclical indicator methods for the construction of composite indicators when data exist in the form of time series. This method is recommended to reduce the risk of receiving false signals and to achieve better forecast cycles for economic activities, by considering the results of business trend surveys in composite indicators. ${ }^{9}$ The following formula exemplifies the cyclical indicator method with the mean $E_{t}\left(x_{q c}^{t}\right) \quad$ over time $:^{10}$

$$
I_{q c}^{t}=\frac{x_{q c}^{t}-E_{t}\left(x_{q c}^{t}\right)}{E_{t}\left|x_{q c}^{t}-E_{t}\left(x_{q c}^{t}\right)\right|}
$$

The percentage of annual differences over consecutive years measures the percentage growth with respect to the previous year instead of the absolute level. As a consequence, the transformation is only applicable if the underlying data is available for a certain number of years. ${ }^{11}$

$$
I_{q c}^{t}=\frac{x_{q c}^{t}-x_{q c}^{t-1}}{x_{q c}^{t}}
$$

Overall, our discussion of the main normalization methods reveals that the selection of a suitable method is not trivial and requires special attention. ${ }^{12}$ Normalization methods should consider the properties of the underlying data, as well as the objective of the indicator summarized. Each method has advantages and disadvantages, and yields a different result. The standardization method and the re-scaling approach are the most commonly used because they have desirable characteristics for data aggregation in composite indicators.

Considering the data in our sample, several countries score rather close to each other. With the re-scaling method, it is possible to widen the spread of country distances. Hence, we prefer the re-scaling method, converting all the variables to a common scale from 1 to 100 with the latter representing the best-performing country.

\footnotetext{
${ }^{8}$ Cf. Nardo et al. (2005a), p. 20.

${ }^{9}$ Cf. Nilsson (2000).

${ }^{10}$ Cf. Nardo et al. (2005a), p. 20.

${ }^{11}$ Cf. Nardo et al. (2005a), p. 20.

${ }^{12}$ Cf. Ebert and Welsh (2004). 


\subsubsection{Aggregation Techniques}

Different aggregation methods may affect the index's results. They can be classified in additive methods, geometric aggregation and non-compensatory multi-criteria analysis. ${ }^{13}$ In this paper, we focus on additive and geometric aggregation methods because they are commonly used in recent research. More information about alternative aggregation techniques can be found in Nardo et al. (2005a, b). Before we explain the advantage and disadvantages of each method, an illustration of the two methods' mathematical background is provided below.

Linear aggregation is one of the additive methods and can be defined as the weighted sum:

$$
C I_{c}=\sum_{q=1}^{Q} w_{q} I_{q c}
$$

Geometric aggregation is defined as:

$$
C I_{c}=\prod_{q=1}^{Q} x_{q, c}^{w_{c}}
$$

$$
\text { with } \sum_{q} w_{q}=1 \text { and } 0 \leq w_{q} \leq 1 \text { for all } q=1, \ldots, Q \text { and } c=1, \ldots, M \text {. }
$$

While the linear aggregation method is useful when all sub-indicators have the same measurement unit, ${ }^{14}$ geometric aggregation is better suited if non-comparable and strictly positive sub-indicators ${ }^{15}$ are expressed in different ratio scales. ${ }^{16}$ Linear aggregation rewards base indicators proportionally to the weights, while geometric aggregation rewards those countries or those sub-indicators with higher scores. ${ }^{17}$ Overall, a shortcoming in one dimension can be compensated by a surplus in another, which implies an inconsistency between how weights are conceived and the actual meaning when geometric or linear aggregation is used. Hence, compensability is constant in linear aggregation while in geometric aggregation, it is lower for the sub-indicators with low values. If compensability is admitted, due to geometric aggregation a country with low scores in one indicator will need a much higher score in the others to improve its situation. Therefore, countries with low scores prefer a linear rather than a geometric aggregation. ${ }^{18}$

Otherwise, under geometric aggregation the marginal utility from an increase in low absolute scores would be much higher. Accordingly, a country would be more interested in increasing those sectors with the lowest score in order to have a greater chance of improving its position in the ranking. Bearing this in mind, this aspect could be one of the aspirations of policymakers. ${ }^{19}$

\footnotetext{
${ }^{13}$ Cf. Nardo et al. (2005a), p. 75.

${ }^{14}$ Note: $f: x \rightarrow \alpha x+\beta_{i} \quad \alpha>0 ; \alpha$ is fixed, but $\beta_{i}$ varying across sub-indicators; Cf. Nardo et al. (2005a), p. 80.

${ }^{15}$ Note: $f: x \rightarrow \alpha_{i} x \quad \alpha_{i}>0 ; \alpha_{i}$ varying across sub-indicators; Cf. Nardo et al. (2005a), p. 80.

${ }^{16} \mathrm{Cf}$. Ebert and Welsch (2004).

${ }^{17}$ Cf. Nardo et al. (2005a), p. 22.

${ }^{18}$ Cf. Nardo et al. (2005a), p. 22.

${ }^{19}$ Cf. Zimmermann and Zysno (1983).
} 


\subsubsection{Weighting Technique}

Weights can have a significant effect on the overall composite indicator and the country rankings. A number of weighting techniques exist in literature. Nardo et al. (2005a, b) provide an overview of the most common techniques, which can be derived from statistical models, such as factor analysis, data envelopment analysis and unobserved components models (UCM), or from participatory methods such as budget allocation processes (BAP), analytic hierarchy processes (AHP) and conjoint analysis (CA). Regardless of which method is used, weights are essentially value judgments. In this paper, we focus on two approaches. First, we apply a neutral approach based on equal weighting. Second, we use factor analysis to calculate the weights based on the statistical properties of the underlying data series. We finally compare both methods in a sensitivity analysis.

\subsubsection{Equal Weighting}

If there are no statistical or empirical grounds for choosing a different scheme, one could use equal weights to aggregate the index items. This implies an equal contribution of all subindicators to real estate attractiveness, which is arguable. However, it is difficult to draw conclusions from the large body of literature available about the importance, and hence the weight, of the individual criteria.

As a first step, we apply equal weights for all data series for our index, when we aggregate them to the level 2 constructs as a neutral weighting scheme. Then we use equal weights for the level 2 constructs to aggregate the six key drivers. Finally, the weight of the key drivers depends on the number of level 2 constructs included in each one. For example, "1 Economic Activity" consists of six level 2 constructs, while "2 Real Estate Market" consists of five. Overall, we use 31 level 2 constructs for the index, and hence, "1 Economic Activity" receives a weight of 6/31, which is 0.194, while the weight of "2 Real Estate Market" is 5/31 - 0.161. Thus, key drivers with more level 2 constructs gain more weight. Table 4 shows the overall weights of each key driver for the equal weighting method set.

\section{Table 5}

Weights for the Key Drivers

\begin{tabular}{lcc} 
& N of Groups & Weights \\
\hline 1. Economic Activity & 6 & 0.194 \\
\hline 2. Real Estate Investment Opportunities & 5 & 0.161 \\
\hline 3. Depth of Capital Market & 6 & 0.194 \\
\hline 4. Investor Protection and Legal Framework & 4 & 0.129 \\
\hline 5. Administrative Burdens and Regulatory Limitations & 6 & 0.194 \\
\hline 6. Socio-cultural and Political Environment & 4 & 0.129 \\
\hline Real Estate Investment Index & 31 & 1.000
\end{tabular}

Overall, the benefit of this method is that the construction and allocation of level 2 constructs to each key drivers is fully neutral due to a fully equal weighting scheme. Hence, level 2 constructs could be switched to other key drivers without having any impact on the index's overall result. 


\subsubsection{Factor Analysis}

In composite index modeling, multivariate analysis is a commonly used method for analyzing dependencies within the data and for gaining advantage by calculating weights according to the statistical properties of the underlying data series. There are a number of weighting techniques derived from statistical models. Manly (1994) discusses principal component analysis. Nardo et al. (2005a) propose factor analysis, and data development analysis. Kaufmann et al. (1999, 2003) use an unobserved component model. Other similar weighting techniques are derived from analytic hierarchy processes, as described in Forman (1983), or Saaty (1987), or from conjoint analysis, as in Green and Srinivasan (1978), Hair et al. (1998), and McDaniel and Gates (1998).

Following the composite index approach of Berlage and Terweduwe (1988), we use the factor analysis technique for the level 2 sub-indices and for the key drivers. The level 3 data series are always aggregated to the level 2 constructs using equal weights. In this weighting method, each component is assigned a weight according to its contribution to the total variance in the data. This is an attractive feature, because it ensures that the resulting summary indicators account for a large part of the cross-country variance of the underlying items. That makes this method independent of prior views on their relative economic importance. This is at once an advantage and a disadvantage. The advantage is that the weights are a result of the underlying data's statistical properties and we do not need to determine weights on our own, which is, in fact, an arbitrary task. The disadvantage is that one might assume that some of the criteria play a dominant role. However, as highlighted in Nicoletti et al. (2000), the properties of factor analysis are particularly desirable for cross-country comparisons. Our sensitivity analysis in a later section of this paper shows the impact of different weighting schemes on the overall result.

A detailed discussion of factor analysis can be found, for instance, in Hair et al. (1998). The general linear factor model for $p$ observed variables and $q$ factors or latent variables takes the form:

$$
x_{i}=\alpha_{i 1} F_{1}+\alpha_{i 2} F_{2}+\ldots+\alpha_{i q} F_{q}+e_{i} \quad(i=1, \ldots, p)
$$

where $x_{i}$ represent standardized variables, and $\alpha_{i 1}, \ldots, \alpha_{i q}$ are factor loadings related to the factors $F_{i}, \ldots, F_{q}$, while $e_{i}$ are residuals. The factors are neither correlated with each other nor with the residuals. Furthermore, they have zero means, and unit variance. Additionally, the residuals are uncorrelated with each other. They have zero means, but not necessarily equal variances.

To run factor analyses properly, we have to drop those items that do not meet the requirements for factor analysis. The Kaiser-Meyer-Olkin Measure of Sampling Adequacy (MSA) is based on the partial correlations among the input variables. The measure should be above 0.5 for each individual variable and likewise for the overall set. In the factor analysis, variables with MSA values below 0.5 should be omitted from the analysis one at a time. With Bartlett's Test of Sphericity, it can be shown that the correlation matrix is not an identity matrix. The test value should be below the 0.05 significance level.

We apply a pooled data set ranging from 2004-2009 for the factor analysis and drop variables when necessary (e.g. 1.3 GDP Growth, 2.2 Degree of Urbanization, 2.3 Urban Population, and 5.1 Taxation). Table 6 shows the consistency analysis of the underlying items on the level of the six key drivers and their MSA values and Bartlett's Test significance values. 


\section{Table 6}

Consistency Analysis of the Underlying Items on the Level of the six Key Drivers

\begin{tabular}{lccc} 
& MSA Value & Bartlett's Test & Items dropped \\
\hline 1. Economic Activity & 0.731 & 0.000 & 1.3 GDP Growth \\
\hline 2. Real Estate Investment Opportunities & 0.583 & 0.000 & $\begin{array}{c}\text { 2.2 Degree of Urbanization } \\
\text { 2.3 Urban Population }\end{array}$ \\
\hline 3. Depth of Capital Market & 0.875 & 0.000 & - \\
\hline 4. Investor Protection and Legal Framework & 0.733 & 0.000 & - \\
\hline $\begin{array}{l}\text { 5. Administrative Burdens and Regulatory } \\
\text { Limitations }\end{array}$ & 0.762 & 0.000 & 5.1 Taxation \\
\hline $\begin{array}{l}\text { 6. Socio-cultural and Political Environment } \\
\text { Real Estate Investment Index }\end{array}$ & 0.809 & 0.000 & - \\
\hline
\end{tabular}

Pooled data set from 2004-2009.

Now, the most common method used to extract the first $m$ components is principal component analysis. The decision of when to stop extracting factors depends on the point when only little "random" variability remains. Various stopping rules have been developed as described in Dunteman (1989): Kaiser's Criterion, Screen Plot, variance explained criteria, Joliffe Criterion, Comprehensibility, Bootstrapped Eigenvalues and Eigenvectors. Kaiser's Criterion is one of the most widely used stopping rules and recommends dropping all factors with an Eigenvalue below one. Due to Kaiser (1958), most of the total variance is determined by components beyond the Eigenvalue of one.

Resulting from the previous consistency checks and analyses, we obtain one single component that represents $76.191 \%$ of the total variance of the underlying data. Consequently, the data sample is fully uni-dimensional, reflecting an ideal measure for a country's attractiveness index (see Table 7).

\section{Table 7}

Total Variance explained by Components

\begin{tabular}{ccccccc}
\hline \multirow{2}{*}{ Component } & \multicolumn{3}{c}{ Initial Eigenvalues } & \multicolumn{2}{c}{ Extraction Sums of Squared Loadings } \\
\cline { 2 - 6 } & Total & \% of Variance & Cumulative \% & Total & \% of Variance & Cumulative \% \\
\hline 1 & 4.751 & 76.191 & 76.191 & 4.571 & 76.191 & 76.191 \\
2 & 0.760 & 12.673 & 88.863 & & \\
3 & 0.231 & 3.848 & 92.711 & & \\
4 & 0.215 & 3.577 & 96.288 & & \\
5 & 0.120 & 1.993 & 98.281 & & \\
6 & 0.103 & 1.719 & 100.000 & & \\
\hline
\end{tabular}

Due to the uni-dimensionality of the data sample, rotation of factors according to Hair et al. (1998) becomes unnecessary. The last step (see Table 8) of the weighting procedure deals with the construction of the weights from the matrix of factor loadings. The square of a factor loading represents the proportion of the indicator's variance explained by the factors. 
According to Nardo et al. (2005a), the component weights are calculated as a linear combination of the proportion of explained variance in the dataset. For instance, for Economic Activity, the weight becomes $0.187(0.187=0.9262 / 4.571)$.

\section{Table 8}

Component Matrix and Calculation of Weights

\begin{tabular}{lcc} 
& $\begin{array}{c}\text { Component } \\
\text { Loadings }\end{array}$ & $\begin{array}{c}\text { Component } \\
\text { Weights } \\
\mathbf{1}\end{array}$ \\
\hline 1. Economic Activity & 0.926 & 0.187 \\
\hline 2. Real Estate Investment Opportunities & 0.892 & 0.174 \\
\hline 3. Depth of Capital Market & 0.768 & 0.129 \\
\hline 4. Investor Protection and Legal Framework & 0.896 & 0.176 \\
\hline 5. Administrative Burdens and Regulatory Limitations & 0.845 & 0.156 \\
\hline 6. Socio-cultural and Political Environment & 0.902 & 0.178 \\
\hline Explained Variance & 4.571 & \\
Explained / Total Variance & 1.000 & $\mathrm{SUM}=1.000$
\end{tabular}

Table 8 presents the weights of the six key drivers using factor analysis. Economic Activity achieves the highest weight, followed by Socio-cultural and Political Environment, Investor Protection and Legal Framework, Real Estate Investment Opportunities, Administrative Burdens and Regulatory Limitations, and finally Depth of Capital Market. However, it becomes obvious that the difference between the weights of the six key drivers is not very large, probably leading to similar results if we applied equal weights to aggregate the sub-indexes. This issue will be addressed in the sensitivity analysis, where we compare the different approaches.

The above three tables present the procedure for determining the weights of the key drivers that have already been aggregated. To determine the key driver scores themselves, we had to perform the analogue procedure one step earlier, using the data and sub-constructs are built from. We present the results of the factor analysis for the key drivers in Appendix C to this paper. Nardo et al. (2005b) discuss the advantages and disadvantages of the factor analysis. Factor analysis can summarize a set of sub-indicators while preserving the maximum possible proportion of the total variation in the original set. This is a very desirable feature for crosscountry comparisons. However, the factor loadings determined may not represent the subindicators' true influence. However, the true influences are still unknown and our index will contribute to solving this problem. Furthermore, factor analysis is highly sensitive to sample modifications due to data revisions or inclusion of additional countries. 


\subsection{Explanatory Power of the Results}

\subsubsection{Back-test}

Previous studies of international real estate investments based their analyses on real estate market returns, prime yields or listed real estate securities, such as REITs. To define market attractiveness, we use six key drivers that influence real estate investment activity per country as dependent variable. This enables us to test the quality of our three different index models i) geometric aggregation with equal weighting; ii) linear aggregation with equal weighting, and iii) geometric aggregation with factor analysis by correlating the index results with actual commercial real estate investment activity. Table 9 presents the correlation coefficients over several years and reveals that all of our index versions correlate reasonably with commercial real estate investment activity in the countries selected from 2004-2009. However, we chose alternative i) as our base case scenario because of its higher correlation coefficients.

\section{Table 9}

Correlation Analysis with Real Estate Investments

Real Estate Investments

\begin{tabular}{|c|c|c|c|c|c|c|c|}
\hline \multicolumn{2}{|l|}{ Index $t=t$} & 2004 & 2005 & 2006 & 2007 & 2008 & 2009 \\
\hline Equal Groups & Pearson Correlation & $.856^{* *}$ & $.859^{* *}$ & $.812^{* *}$ & $.782^{* *}$ & $.768^{* *}$ & $.731^{* *}$ \\
\hline \multirow[t]{2}{*}{ Geom. Agg. } & Sig. (2-tailed) & .000 & .000 & .000 & .000 & .000 & .000 \\
\hline & $\mathrm{N}$ & 33 & 34 & 34 & 43 & 45 & 46 \\
\hline Equal Groups & Pearson Correlation & $.845^{\star *}$ & $.843^{* *}$ & $.800^{* *}$ & $.761^{\star *}$ & $.733^{\star *}$ & $.660^{* *}$ \\
\hline \multirow[t]{2}{*}{ Linear Agg. } & Sig. (2-tailed) & .000 & .000 & .000 & .000 & .000 & .000 \\
\hline & $\mathrm{N}$ & 33 & 34 & 34 & 43 & 45 & 46 \\
\hline Factor Analysis & Pearson Correlation & $.807^{\star \star}$ & $.809^{* *}$ & $.757^{\star *}$ & $.731^{* *}$ & $.698^{\star \star}$ & $.609^{* *}$ \\
\hline \multirow[t]{2}{*}{ Geom. Agg. } & Sig. (2-tailed) & .000 & .000 & .000 & .000 & .000 & .000 \\
\hline & $\mathrm{N}$ & 33 & 34 & 34 & 43 & 45 & 46 \\
\hline
\end{tabular}

*. Correlation is significant at the 0.05 level (2-tailed).

**. Correlation is significant at the 0.01 level (2-tailed).

The control variable is the natural logarithm of Real Estate Investments in USD mn. (3 years average). The correlation is calculated: index (t) with control variable (t).

\subsubsection{Sensitivity Analysis}

We have also performed a sensitivity analysis in order to determine whether our results are robust for different aggregation and weighting methods. We primarily focus on the weighting scheme, because one of the most arbitrary choices remains setting the weights for the aggregation of the underlying variables when constructing composite indices. Figure 1 shows the shifts in ranking positions for the various construction methods. The larger a country's amplitude is, the greater the variance (difference between minimum and maximum ranking position) in the ranking with respect to the change in construction methods. However, we finally obtain an average shift of 4.24 ranking positions among the 66 countries, which we interpret as a good result. Hence, we claim that our index is robust towards different calculation methods. 


\section{Figure 1}

Sensitivity Analysis

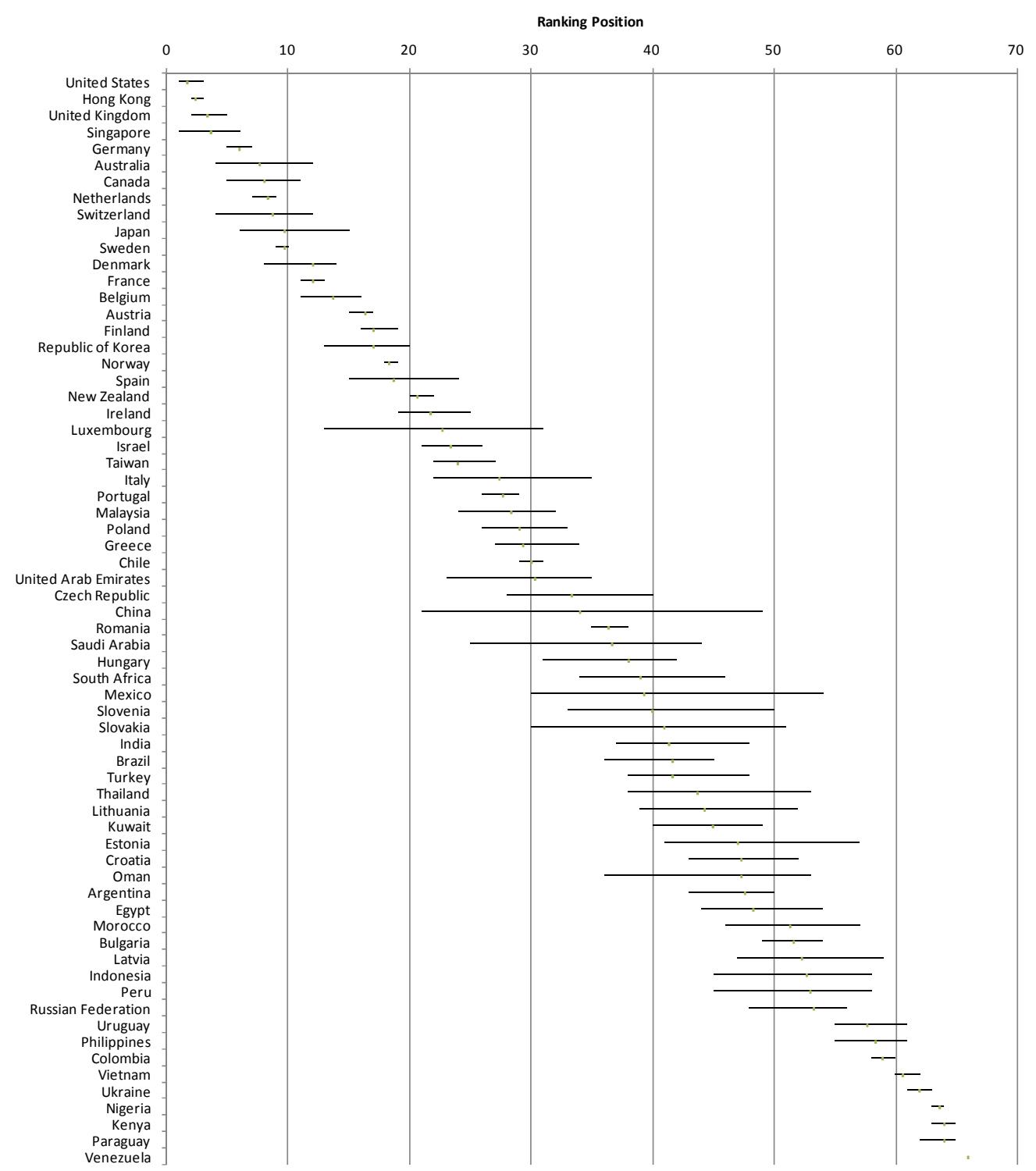

Index 1): Rescaled, equal weights, geometric aggregation; Index 2): Rescaled, equal weights, linear aggregation; Index 3): Rescaled, factor analysis, geometric aggregation.

\subsubsection{Comparison with alternative Composite Indices}

Chen and Hobbs (2003) develop a Global Real Estate Risk (GRER) index for 44 countries based on three components: country, structural and cyclical real estate risks. The authors argue that these three measures capture the key dimensions of international real estate risk. They apply factor analysis according to the approach presented in our paper. However, they finally weigh the three key drivers manually, depending on the portion of particular risk that should be captured by the investment strategy, such as "core" and "opportunistic." Unfortunately, due to the proprietary nature of the authors' work, they provide little or no information on individual countries and only summarize the results by ranking the countries as either "Opportunistic" or "Core." 
Lee (2005) assesses the potential of 51 countries for international investments by developing a Real Estate Potential Index (REP Index) based on four components: expected growth, country risk, transparency, and market specific risk. Except for expected growth, where he relies on the expected five-year GDP growth, he uses the Euromoney Country Risk (ECR) index, which is based on survey data, and the JLL Global Transparency Index, which is explained below. The component, which captures the real estate market's specific risk, is a self-constructed component containing only a few of the composites that we consider in our analysis. He finally aggregates the components via equal weights resulting in a similar ranking for 2005 and hence, a high correlation of 0.875 with our index.

Finally, the property management company Jones Lang LaSalle developed a Global Real Estate Transparency (GRET) Index in 1999. This index is based on a structured survey conducted within LaSalle Investment Managers and covers the following five key attributes of real estate transparency: 1) Legal factors; 2) Regulatory burden; 3) Availability of information on market fundamentals; 4) Listed vehicle financial disclosure and governance, and 5) Availability of investment performance. The data are gathered via questionnaires and aggregated using an equal weighting scheme. The composite scores range between 1 (best level of transparency) and 5 (opacity). The final ranking groups countries into five broad tiers of transparency: Tier 1: Highly Transparent; Tier 2: Transparent; Tier 3: Semi-Transparent; Tier 4: Low Transparency, and Tier 5: Opaque. We compare the GRET index ranking with our Global REIA Index and obtain a reasonable correlation of 0.835 for the years 2004-2008.

Even though all indices seem to be similar, Table 10 shows that our construct is superior in terms of its correlation with actual real estate investment activity.

\section{Table 10}

Comparison with Alternative Indices

\begin{tabular}{|c|c|c|c|c|c|c|c|}
\hline & & $\begin{array}{l}\text { Invest- } \\
\text { ments }\end{array}$ & $\begin{array}{c}\text { Global REIA } \\
\text { Index }\end{array}$ & GRET Index & Lee Index & $\begin{array}{c}\text { Chen \& } \\
\text { Hobbs Opp. } \\
\text { Index }\end{array}$ & $\begin{array}{c}\text { Chen \& } \\
\text { Hobbs Core } \\
\text { Index }\end{array}$ \\
\hline Global & Spearman's rho & $.821^{\star \star}$ & 1.000 & $.835^{\star *}$ & $.875^{\star \star}$ & .334 & .225 \\
\hline \multirow[t]{2}{*}{ Index } & Sig. (2-tailed) & .000 & & .000 & .000 & .150 & .355 \\
\hline & $\mathrm{N}$ & 189 & 330 & 183 & 46 & 20 & 19 \\
\hline \multirow[t]{3}{*}{ GRET Index } & Spearman's rho & $.676^{\star \star}$ & $.835^{\star \star}$ & 1.000 & & & \\
\hline & Sig. (2-tailed) & .000 & .000 & & $\mathrm{n} / \mathrm{a}$ & $\mathrm{n} / \mathrm{a}$ & $\mathrm{n} / \mathrm{a}$ \\
\hline & $\mathrm{N}$ & 119 & 183 & 183 & & & \\
\hline \multirow[t]{3}{*}{ Lee Index } & Spearman's rho & $.782^{\star \star}$ & $.875^{\star \star}$ & & 1.000 & & \\
\hline & Sig. (2-tailed) & .000 & .000 & $\mathrm{n} / \mathrm{a}$ & & $\mathrm{n} / \mathrm{a}$ & $\mathrm{n} / \mathrm{a}$ \\
\hline & $\mathrm{N}$ & 28 & 46 & & 46 & & \\
\hline Chen \& Hobbs & Spearman's rho & .235 & .334 & & & 1.000 & .370 \\
\hline \multirow[t]{2}{*}{ Opp. Index } & Sig. (2-tailed) & .363 & .150 & $\mathrm{n} / \mathrm{a}$ & $\mathrm{n} / \mathrm{a}$ & & .144 \\
\hline & $\mathrm{N}$ & 17 & 20 & & & 20 & 17 \\
\hline Chen \& Hobbs & Spearman's rho & .014 & .225 & & & .370 & 1.000 \\
\hline \multirow[t]{2}{*}{ Core Index } & Sig. (2-tailed) & .960 & .355 & $\mathrm{n} / \mathrm{a}$ & $\mathrm{n} / \mathrm{a}$ & .144 & \\
\hline & $\mathrm{N}$ & 15 & 19 & & & 17 & 19 \\
\hline
\end{tabular}

*. Correlation is significant at the 0.05 level (2-tailed).

**. Correlation is significant at the 0.01 level (2-tailed).

All data are ranked over the entire country sample for comparative purposes, implying that Spearman's rho is used as calculation method for monotone data series. The control variable is the natural logarithm of Real Estate Investments in USD mn. (3 years average).

Time series applied for Global REIA Index: 2004-2008, GRET Index: 2006-2008, Lee Index: 2005, Chen and Hobbs: 2004. 


\section{The Attractiveness of Countries for Real Estate Investors}

\subsection{Country Ranking according to our Global REIA Index}

Applying the aforementioned procedure, we obtain a global country ranking for our base case index as shown in Figure 2. We chose the United States as benchmark country in order to facilitate further analyses and comparisons due to the fact that the United States obtains the highest index score and that it has always been the most active country for real estate investments. Hence, we rescale all composites by setting the United States to 100 points.

\section{Figure 2}

Country Score and Ranking to the REIA Index 2009/2010

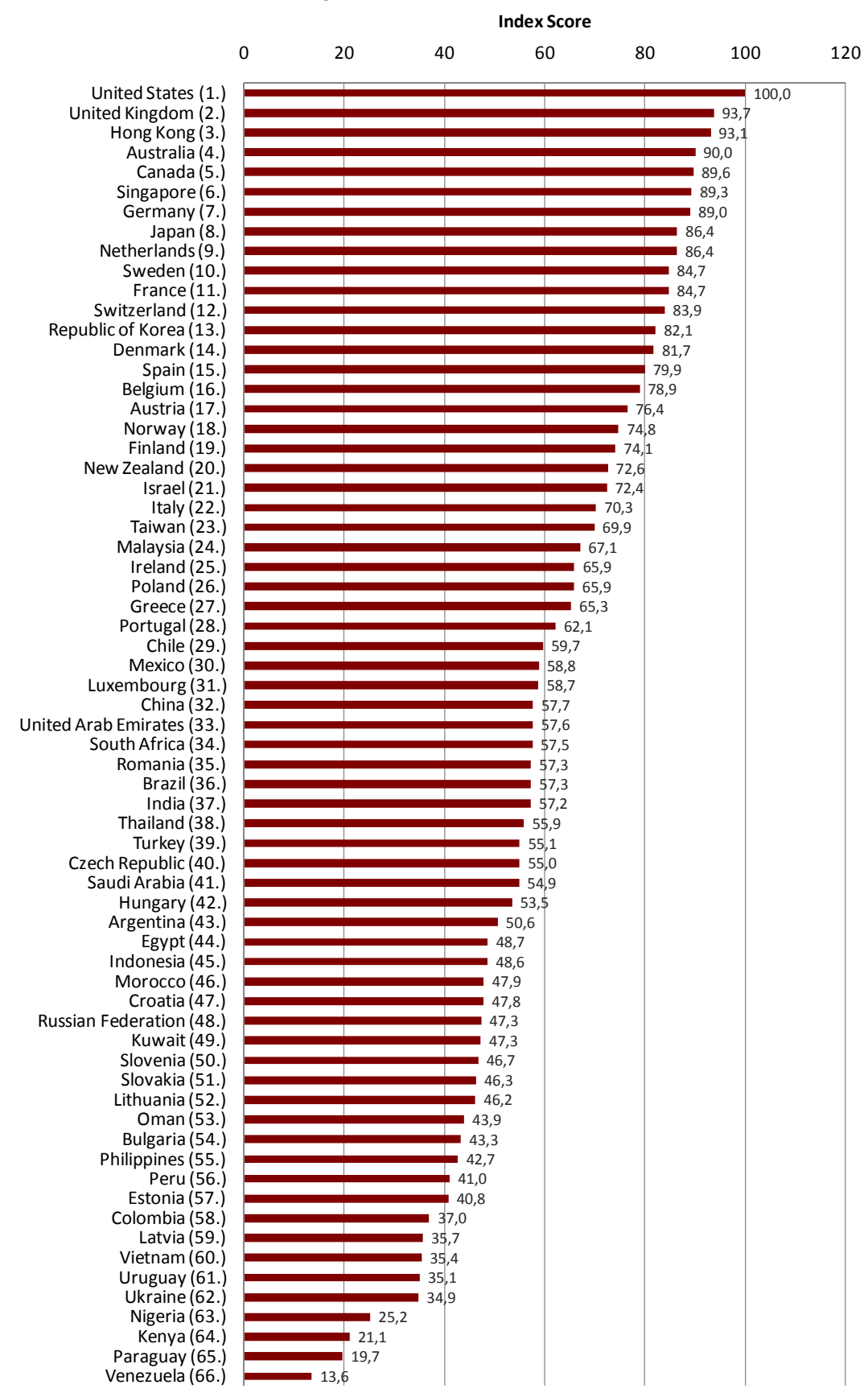

Benchmark: United States $=100$ points. Composite index: rescaled, geometric aggregation, equal-weighted. 
The United States is followed by the United Kingdom and Hong Kong. The countries score high with respect to all key driving forces, but above all, because of their sound real estate market fundamentals, and a transparent institutional framework. Emerging markets like Venezuela, Paraguay and Kenya, which comprise the last three positions of the overall ranking, suffer in terms of their economic performance and their institutional framework, which is characterized by a lack of transparency and by stability issues.

The ranking submits that maturity is a key concept in countries' attractiveness as it takes into account the nature and evolution of the markets, as well as their economic, social and institutional condition. Particularly, aspects of political stability, restrictions and regulation on foreign investors, legal framework, legal regulation, sound financial and economic structure, and the economy's strength and stability are very sensitive in spurring real estate investment activity. For detailed information on the characteristics of the 66 countries, we refer to Appendix D: Detailed Figures and Tables: Figure A 1.

\subsection{Strengths and Weaknesses of Developed, Transition and Emerging Markets}

While the Western European countries have a long-established tradition for their real estate markets, the emerging regions have attracted considerable attention only recently. A remaining question is still why the United States has such a high investment level compared with other countries. Table 11 shows our index results on a regional level for the economic groups defined in Table 2. We contribute to market transparency by highlighting the differences in the factors that attract real estate investments. Thus, an active economy, with sophisticated real estate investment opportunities, deep and liquid capital markets, protection of legal and property rights, low burdens of doing business, and finally a stable socio-cultural and political environment spur investments within the North American region.

\section{Table 11}

Strengths and Weaknesses of Developed, Transition and Emerging Regions

\begin{tabular}{|c|c|c|c|c|c|c|c|}
\hline Country/Region & Rank & $\begin{array}{l}\text { 1. Economic } \\
\text { Activity }\end{array}$ & $\begin{array}{l}\text { 2. Real Estate } \\
\text { Investment } \\
\text { Opportunities }\end{array}$ & $\begin{array}{l}\text { 3. Depth of } \\
\text { Capital Market }\end{array}$ & $\begin{array}{c}\text { 4. Investor } \\
\text { Protection and } \\
\text { Legal Framework }\end{array}$ & $\begin{array}{l}\text { 5. Administrative } \\
\text { Burdens and } \\
\text { Regulatory } \\
\text { Limitations }\end{array}$ & $\begin{array}{l}\text { 6. Socio-Cultural } \\
\text { and Political } \\
\text { Environment }\end{array}$ \\
\hline North America & 1 & 98 & 88 & 94 & 101 & 103 & 109 \\
\hline Australasia & $\|$ & 89 & 57 & 67 & 106 & 105 & 121 \\
\hline Western Europe & III & 85 & 61 & 61 & 87 & 110 & 112 \\
\hline Asia & IV & 83 & 66 & 64 & 67 & 89 & 69 \\
\hline Middle East & v & 77 & 41 & 41 & 64 & 94 & 74 \\
\hline Eastern Europe & VI & 70 & 45 & 27 & 68 & 99 & 79 \\
\hline Latin America & VII & 67 & 51 & 28 & $4 \overline{7}$ & 88 & 56 \\
\hline Africa & VIII & 56 & 43 & 31 & 53 & 78 & 36 \\
\hline
\end{tabular}

Benchmark: United States $=100$ points.

Even if the Australasian and Western European regions show sound and stable economies, Table 11 points out that the weaknesses of these regions stem from the disparities of urbanization and agglomeration centers, providing investors with fewer target markets for investments. Furthermore, the lower size and liquidity of domestic capital markets (compared to 
the United States) seem to hamper investment activity there. The transition and emerging regions suffer even more from this obstacle.

In transition markets such as some countries in Asia, the Middle East and Eastern Europe, the lack of certain institutional factors affects their attractiveness. Even if the burden of doing business does not differ significantly from the developed markets, the lack of protection of legal and property rights affects attractiveness in those countries. Furthermore, the regions are characterized by a less attractive socio-cultural and political environment for investments, and by a higher level of perceived corruption and political uncertainty. The investment risks with respect to legal protection and socio-political instabilities increase even further in Latin America and Africa.

\section{Conclusions and Further Research}

Since real estate assets are not publicly traded on centralized exchanges, the physical real estate market is characterized by a relative lack of liquidity, large transaction sizes and costs for nonhomogenous and immovable properties. The low transparency of the real estate marketplace results in information asymmetries. When investing internationally, investors face further challenges arising from the lack of experience in the foreign markets' structure, and the particularities of "how local real estate business is done." Indeed, investing internationally means venturing into the unknown and the lack of information and transparency leads to an increased perception of risk. Our goal is to increase the transparency of international real estate markets by measuring and scoring the important country variables for global real estate allocations.

We assess the attractiveness of 66 countries worldwide and obtain a country ranking using a composite measure. We normalize the data and show that the composition of our index is consistent by testing for uni-dimensionality. We determine different weighting schemes based on equal weights and on factor analysis and achieve rankings which correlate reasonably with actual real estate investments. Furthermore, sensitivity analyses and comparison with alternative composite indices provide evidence that our methodology is appropriate, unique, and robust. We give an overview of the strengths and weaknesses of developed, transition and emerging markets with respect to the six key drivers we have defined: Economic Activity, Real Estate Investment Opportunities, Depth and Sophistication of Capital Markets, Investor Protection and Legal Framework, Administrative Burdens and Regulatory Limitations, and Socio-cultural and Political Environment. Our index structure allows the key drivers to be analyzed on a more granulated level and we discuss the disparities between developed, transition and emerging countries. We conclude that there exist numerous institutional differences, which affect the investment decisions of globally acting investors and hence, shape these national real estate markets.

Maturity is a key concept in investors' decision-making as it takes into account the markets' nature and evolution, as well as their economic, social and institutional conditions. Particularly, aspects of political stability, restrictions and regulation on foreign investors, legal framework, legal regulation, sound financial and economic structure, and the economy's strength and stability are very sensitive for investors' market perception.

Space limitations prevent us from presenting more detailed analyses. Hence, we only show a small fraction of the potential offered by the Global REIA Index. Future steps include analyses of time-varying effects on particular indicators and attempts to optimize the index's structure. However, we leave these issues for further research. 


\section{References}

Adair, A., Berry, J.; McGreal, S.; Syacutekora, L.; Ghanbari Parsa, A., and Redding, B. (1999), "Globalization of real estate markets in Central Europe," In: "European Planning Studies," Vol. 7, No. 3, June, pp. 295-305.

Adlington, Gavin; Grover, Richard; Heywood, Mark; Keith, Simon; Munro-Faure, Paul, and Perrotta, Louise (2008), "Developing Real Estate Markets in Transition Economies," In: "UN Intergovernmental Conference Paper,” RICS Research Foundation, 6-8, December 2008.

Ball, M.; Lizieri, C., and MacGregor, B. N. (1998), "The Economics of Commercial Property Markets," London: Routledge, 1998.

Baum, Andrew E. (1995), “Can Foreign Real Estate Investment Be Successful?,” In: “Journal of Real Estate Finance,” Spring, pp. 81-89.

Baum, Andrew E. and Crosby, B. (1988), “Property Investment Appraisal,” London: Routledge.

Berlage, L. and Terweduwe, D. (1988), "The classification of countries by cluster and by factor analysis," World Development, Vol. 16, No. 12, pp. 1527-1545.

Brinson, G. P. and Hood, L. R. (1986), “Determinants of Portfolio Performance," Financial Analyst Journal, Vol. 51, No. 1, pp. 133-138.

Brinson, G. P.; Singer, B. D., and Beebower, G. L. (1991), "Determinants of Portfolio Performance II," Financial Analyst Journal, Vol. 47, No. 3, pp. 40-48.

Chen, Jun and Hobbs, Peter (2003), "Global Real Estate Risk Index - To capture different levels of market risk," The Journal of Portfolio Management, Special Issue, pp. 66-76.

Chin, Wei; Dent, Peter, and Roberts, Claire (2006), "An Explanatory Analysis of Barriers to Investment and Market Maturity in Southeast Asian Cities," Journal of Real Estate Portfolio Management, Vol. 12, No. 1, pp. 49-57.

Connor, Philip and Liang, Youguo (2000), "Four Forces Shaping the Commercial Real Estate Industry," Pramerica Financial Research, November.

Connor, Philip and Liang, Youguo (2005), "Global REITs: A New Platform of Ownership," Prudential Real Estate Investors Research, January.

Corcoran, Patrick J. (1987), "Explaining the Commercial Real Estate Market," Journal of Portfolio Management, Vol. 13, No. 3, pp. 15-21.

Cortina, J. M. (1993), "What is coefficient alpha? An examination of theory and applications," Journal of Applied Psychology, Vol. 78, No. 1, pp. 98-104.

Cronbach, L. J. (1951), "Coefficient alpha and the international structure of tests," Psychometrika, Vol. 16, pp. 297-334.

D’Arcy, Eámonn and Lee, Stephen (1998), “A Real Estate Portfolio Strategy for Europe: A Review of the Options," Journal of Real Estate Portfolio Management, Vol. 4, No. 2, pp. 113-123. 
D’Arcy, Eámonn and Keogh, Geoffrey (1998), "Territorial Competition and Property Market Process: An Explanatory Analysis,” Journal of Urban Studies, Vol. 35, No. 8, pp. 1215-1230.

DiPasquale, Denise and Wheaton, William C. (1992), "The Markets for Real Estate and Space: A Conceptual Framework," Journal of the American Real Estate and Urban Economics Association, Vol. 20, No. 1, pp. 181-197.

Djankov, S.; La Porta, R.; Lopez-de-Silanes, F., and Shleifer, A. (2002), "The regulation of entry," Quarterly Journal of Economics, Vol. 117, No. 1, pp. 1-37.

Djankov, S.; La Porta, R.; Lopez-de-Silanes, F., and Shleifer, A. (2003), "Courts," Quarterly Journal of Economics, Vol. 118, No. 2, pp. 453-517.

Djankov, S.; La Porta, R.; Lopez-de-Silanes, F., and Shleifer, A. (2005), "The Law and Economics of Self-Dealing," NBER working paper 11883.

Djankov, S.; Ganser, T.; McLiesh, C.; Ramalho, R., and Shleifer, A. (2008), "The effect of corporate taxes on investment and entrepreneurship," NBER working paper 13756.

Dunteman, G. H. (1989), “Principal components analysis,” Newbury Park.

Ebert, U. and Welsch, H. (2004), "Meaningful environmental indices: a social choice approach," Journal of Environmental Economics and Management, Vol. 47, pp. 270-283.

Falkenbach, Heidi (2009), "Market Selection for International Real Estate Investments," International Journal of Strategic Property Management, Vol. 13, pp. 299-308.

Feldt, L. S.; Woodruffe, D. J., and Salih, F. A. (1987), "Statistical Inference for Coefficient Alpha,” Applied Psychological Measurement, Vol. 11, No. 1, pp. 93-103.

Fisher, Jeffrey D. and Webb, R. Brian (1992), "Current Issues in the Analysis of Commercial Real Estate," Journal of the American Real Estate and Urban Economics Association, Vol. 20, No. 1, pp. 211-227.

Fisher, Jeffrey D. and Sirmans, C. F. (1993), "The Role of Commercial Real Estate in Multi-Asset Portfolio," University of Connecticut, Centre for Real Estate and Urban Economic Studies, April.

Freudenberg, M. (2003), "Composite indicators of country performance: a critical assessment," OECD Economics Department working paper JT00139910.

Geurts, Tom G. and Jaffe, Austin J. (1996), “Risk and Real Estate Investment: An International Perspective,” The Journal of Real Estate Research, Vol. 11, No. 2, pp. 117-130.

Glaeser, E. L.; Johnson, S., and Shleifer, A. (2001), “Coase vs. the Coasians," Quarterly Journal of Economics, Vol. 116, pp. 853-899.

Green, S. B.; Lissitz, R. W., and Mulaik, S. A. (1977), "Limitations of coefficient alpha as an index of test unidimensionality," Educational and Psychological Measurement, Vol. 37, pp. 827-838.

Green, P. E. and Srinivasan, V. (1978), "Conjoint analysis in consumer research: issues and outlook,” Journal of Consumer Research, Vol. 5, pp. 103-123.

Green, P. G. (1998), “Dimensions of Perceived Entrepreneurial Obstacles.” In: P. Reynolds (ed.), "Frontiers of Entrepreneurship Research," Babson Park: Center for Entrepreneurial Studies, Babson College, pp. 48-49. 
Hair, J. F.; Anderson, R. E.; Tatham, R. L., and Black, W. C. (1998), "Multivariate Data Analysis," Fifth ed., Englewood Cliffs.

Hartzell, David J. and Webb, R. Brian (1993), "Commercial Real Estate and Inflation During Periods of High and Low Vacancy Rates," Working paper, Real Estate Research Institute Boston.

Hattie, J. (1985), "Methodology Review: Assessing unidimensionality of test and items," Applied Psychological Measurement, Vol. 9, No. 2, pp. 139-164.

Hendershott, Patrick H.; Lizieri, C. M., and Matysiak, G. A. (1999), “The Workings of the London Office Market,” Real Estate Economics, Vol. 27, No. 2, pp. 365-387.

Hoesli, Martin and MacGregor, Bryan D. (2000), "Property investment: principles and practice of portfolio management," Pearson Education Limited.

Hoskin, Nicholas; Higgins, David, and Cardew, Richard (2004), "Macroeconomic Variables and Real Estate Returns: An International Comparison,” The Appraisal Journal, Spring, pp. 163-170.

Jacobs, R.; Smith, P., and Goddard, M. (2004), "Measuring performance: an examination of composite performance indicators," Centre for Health Economics, technical paper series 29.

Jaffe, Austin J. and Louziotis, Demetrios Jr. (1996), "Property Rights and Economic Efficiency: A Survey of Institutional Factors,” Journal of Real Estate Literature, Vol. 4, pp. 137-159.

Kaiser, H. F. (1958), "The varimax criterion for analytic rotation in factor analysis," Psychometrika, Vol. 23, pp. 187-200.

Keogh, Geoffrey and D’Arcy, Eámonn (1999), "Property Market Efficiency: An Institutional Economics Perspective,” Journal of Urban Studies, Vol. 36, No. 13, pp. 2401-2414.

Kline, R. B. (1998), "Principles and practice of structural equation modeling," New York.

Knack, S. and Keefer, P. (1995), Institutions and economic performance: Cross-country tests using alternative institutional measures," Economics and Politics, Vol. 7, No. 3, pp. 207-228.

Kurzrock, Björn-Martin; Rottke, Nico B., and Schiereck, Dirk (2007), "Influence Factors on the Performance of Direct Property Investments," Real Estate Management Institute (REMI) Working Paper Series, Vol. 5.

Laposa, Steven and Lizieri, Colin (2005), "Real Estate Capital Flows and Transitional Economies," Conference Paper, ARES Meeting, Santa Fee, NM, 13-16 April.

La Porta, R.; López-de-Silanes, F.; Shleifer, A., and Vishny, R. (1997), "Legal Determinants of External Finance," Journal of Finance, Vol. 52, No. 3, pp. 1131-1150.

La Porta, R.; López-de-Silanes, F.; Shleifer, A., and Vishny, R. (1998), "Law and finance," Journal of Political Economy, Vol. 106, No. 6, pp. 1113-1155.

La Porta, R.; López-de-Silanes, F.; Shleifer, A., and Vishny, R. (2002), "Investor Protection and Corporate Valuation,” Journal of Finance, Vol. 57, No. 3, pp. 1147-1170.

Lee, Stephen (2001), "The Risks of Investing in the Real Estate Markets of the Asian Region," Working Paper of Department of Land Management, The University of Reading, No. 6. 
Lee, Stephen (2005), “Gauging the Investment Potential of International Real Estate Markets," Working Paper of Real Estate and Planning, The University of Reading, No. 19.

Lee, Stephen (2006), "The Impact of Country Risk on International Real Estate Returns," Working Paper of Real Estate and Planning, The University of Reading, No. 10.

Liang, Youguo and Gordon, Nancy M. (2003), “A Bird's Eye View of Global Real Estate Markets," Pramerica Financial Research, March.

Lim, Lay Cheng; McGreal, Stanley, and Webb, James R. (2006), "Perception of Real Estate Investment Opportunities in Central/South America and Africa," Journal of Real Estate Portfolio Management, Vol. 12, No. 3, pp. 261-276.

Lizieri, Colin and Finlay, Louise (1995), "International property portfolio strategies," Journal of Property Valuation \& Investment, Vol. 13, No. 1, pp. 6-21.

Lynn, David J. (2007), "The Tectonic Forces of Global Real Estate: Implications for Global Investment and Portfolio Managers," Journal of Real Estate Portfolio Management, Vol. 13, No. 1, pp. 87-92.

Manly, B. (1994), “Multivariate statistical methods,” London.

Mauro, P. (1995), “Corruption and growth,” Quarterly Journal of Economics, Vol. 110, pp. 681-712.

McDaniel, C. and Gates, R. (1998), “Contemporary Marketing Research,” Cincinnati.

McGreal, Stanely; Parsa, Ali, and Keivani, Ramin (2001), "Perceptions of Real Estate Markets in Central Europe: A Survey of European Investor," Journal of Real Estate Literature, Vol. 9, No. 2, pp. 147-160.

Miller, M. B. (1995), "Coefficient Alpha: A basic introduction from the perspectives of classical test theory and structural equation modeling," Structural Equation Modeling, Vol. 2, No. 3, pp. 255-273.

Mueller, Glenn R. (1995), “Understanding Real Estate’s Physical and Financial Market Cycles," Journal of Real Estate Finance, Spring, pp. 47-52.

Mueller, Glenn R. (1999), "Real Estate Rental Growth Rates at Different Points in the Physical Cycle," Journal of Real Estate Research, Vol. 18, No. 1, pp. 131-150.

Nanthakumaran, N.; O'Roarty, B., and Orr, Allison (1996), “The Impact of Economic Indicators on Industrial Property Market Performance," Paper presented at the Second Pacific Rim Real Estate Society Conference, Sanctuary Cove, Queensland Australia, January 22-24.

Nardo, M.; Saisana, M.; Saltelli, A.; Tarantola, S., Hoffman, A., and Giovannini, E. (2005a), "Handbook on constructing composite indicators: Methodology and user guide," OECD statistics working paper STD/DOC(2005)3.

Nardo, M.; Saisana, M.; Saltelli, A., and Tarantola, S. (2005b), "Tools for Composite Indicators Building,” European Commission, Joint Research Centre working paper EUR 21682 EN.

Newell, Graeme (1995), "Inflation-Hedging Attributes of Australian Commercial Property," Australian Land Economics Review, Vol. 1, No. 1, pp. 31-37. 
Newell, Graeme and Higgins, David (1996), "Impact of Leading Economic Indicators on Commercial Property Performance," The Valuer and Land Economist, Vol. 34, No. 2, pp. 138-144.

Newell, Graeme and Webb, James (1996), “Assessing Risk for International Real Estate Investments,” The Journal of Real Estate Research, Vol. 11, No. 2, pp. 103-115.

Nicoletti, G.; Scarpetta, S., and Boylaud, 0. (2000), "Summary indicators of product market regulation with an extension to employment protection legislation," OECD, Economics Department working paper 226, ECO/WKP(99)18.

Nunnally J. (1978), “Psychometric Theory,” New York.

Roulac, Stephen E. and King, Donald A. (1978), "Institutional Strategies for Real Estate Investment," The Appraisal Journal, April, pp. 257-270.

Roulac, Stephen E. and Gilbert, D. E. (1993), "Economics: A Most Useful Tool for the Valuer," The Valuer and Land Economist, November, pp. 580-584.

Roulac, Stephen E. (1995), "Strategic Decision Models: Multiple Perceptions, Unifying Structure," Journal of Real Estate Research, Vol. 10, No. 5, pp. 495-508.

Roulac, Stephen E. (1996a), "Real Estate Market Cycles, Transformation Forces and Structural Change,” Journal of Real Estate Portfolio Management, Vol. 2, No. 1, pp. 1-17.

Roulac, Stephen E. (1996b), "The Strategic Real Estate Framework: Processes, Linkages, Decision," Journal of Real Estate Research, Vol. 12, No. 3, pp. 323-346.

Saaty, R. W. (1987), "The analytical hierarchy process: what it is and how it is used," Mathematical Modeling, Vol. 9, pp. 161-176.

Saunders, A. and Lange, H. (1996), "Financial Institutions Management: A Modern Perspective," $1^{\text {st }}$ Australian ed., Irwin, Artarmon.

Shun, C. K. L. (2004), “An Empirical Investigation of the Role of the Legal Origin on the Performance of Property Stocks,” Unpublished PhD Henley Management College, Brunel University.

Sirmans, C. F. and Worzala, Elaine (2003), "International Direct Real Estate Investment: A Review of the Literature," Journal of Urban Studies, Vol. 40, Nos. 5-6, pp. 1081-1114.

Solnik, Bruno (1999), "International Investments, " $4^{\text {th }}$ edition, Massachusetts: Addison-Wesley.

Svensson, J. (1998), "Investment, property rights and political instability: Theory and evidence," European Economic Review, Vol. 42, No. 7, pp. 1317-1341.

Taha, Hamdy A. (2007), "Operations Research: An Introduction," $8^{\text {th }}$ edition, Upper Saddle River, New Jersey: Pearson - Prentice Hall.

Thrall, Grant Ian (2002), "Business Geography and New Real Estate Market Analysis," Oxford University Press: New York and Oxford.

Van Doorn, Lisette (2003), "Investing in Europe: The way to diversify," In: IPD Compendium of Real Estate Papers, paper presented at the IPD European Property Strategies Conference, Wiesbaden.

Worzala, Elaine (1994), "Overseas Property Investments - How Are They Perceived by the Institutional Investor?,” Journal of Property Valuation \& Investment, Vol. 12, No. 3, pp. 31-47. 
Worzala, Elaine and Bernasek, Alexandra (1996), "European Economic Integration and Commercial Real Estate Markets: An Analysis of Trends in Market Determinants," The Journal of Real Estate Research, Vol. 11, No. 2, pp. 159-181.

Worzala, Elaine and Newell, Graeme (1997), “International Real Estate: A Review of Strategic Investment Issues”, Journal of Real Estate Portfolio Management, Vol. 3, No. 2, pp. 87-96.

Zimmermann H. J. and Zysno P. (1983), "Decisions and evaluations by hierarchical aggregation of information," Fuzzy Sets and Systems, Vol. 10, pp. 243-260. 


\section{Appendix A}

Description of the Data Sample

\begin{tabular}{|c|c|c|c|c|c|}
\hline \# & Name & Unit & Impact & Description & Source \\
\hline \multicolumn{6}{|c|}{ Denominators } \\
\hline D1 & Population & $\begin{array}{l}\text { [in } \\
\text { millions] }\end{array}$ & & $\begin{array}{l}\text { Total population is based on the de facto definition } \\
\text { of population, which counts all residents regardless } \\
\text { of legal status or citizenship-except for refugees not } \\
\text { permanently settled in the country of asylum, who } \\
\text { are generally considered part of the population of } \\
\text { their country of origin. }\end{array}$ & $\begin{array}{l}\text { IMF, UNFPA State of } \\
\text { World Population } 2008 \\
\text { for values in } 2008, \\
\text { UNFPA State of World } \\
\text { Population } 2007 \text { for } \\
\text { values in } 2007\end{array}$ \\
\hline D2 & GDP & $\begin{array}{l}\text { [USD } \\
\mathrm{mn}]\end{array}$ & & $\begin{array}{l}\text { GDP at purchaser's prices is the sum of gross value } \\
\text { added by all resident producers in the economy plus } \\
\text { any product taxes and minus any subsidies not } \\
\text { included in the value of the products. It is calculated } \\
\text { without making deductions for depreciation of } \\
\text { fabricated assets or for depletion and degradation of } \\
\text { natural resources. Data are in current United States } \\
\text { dollars. Dollar figures for GDP are converted from } \\
\text { domestic currencies using single-year official } \\
\text { exchange rates. For a few countries where the } \\
\text { official exchange rate does not reflect the rate } \\
\text { effectively applied to actual foreign exchange } \\
\text { transactions, an alternative conversion factor is used. }\end{array}$ & $\begin{array}{l}\text { Euromonitor } \\
\text { International from } \\
\text { International Monetary } \\
\text { Fund (IMF), } \\
\text { International Financial } \\
\text { Statistics }\end{array}$ \\
\hline D3 & Land Surface & [sq. km] & & $\begin{array}{l}\text { Land area is a country's total area, excluding area } \\
\text { under inland water bodies, national claims to } \\
\text { continental shelf, and exclusive economic zones. In } \\
\text { most cases the definition of inland water bodies } \\
\text { includes major rivers and lakes. }\end{array}$ & $\begin{array}{l}\text { World Development } \\
\text { Indicators Database }\end{array}$ \\
\hline \multicolumn{6}{|c|}{ Dependent Variables } \\
\hline Dep. 1 & $\begin{array}{l}\text { Commercial } \\
\text { Real Estate } \\
\text { Investments } \\
\end{array}$ & $\begin{array}{l}\text { [LN USD } \\
\mathrm{mn}]\end{array}$ & & $\begin{array}{l}\text { Yearly amount of commercial real estate } \\
\text { investments }\end{array}$ & $\begin{array}{l}\text { Cushman and } \\
\text { Wakefield: Investment } \\
\text { Atlas }\end{array}$ \\
\hline Dep. 2 & $\begin{array}{l}\text { Real Estate } \\
\text { Market } \\
\text { Returns } \\
\end{array}$ & [\%] & & Yearly market returns & $\begin{array}{l}\text { Investment Property } \\
\text { Database (IPD) }\end{array}$ \\
\hline \multicolumn{6}{|c|}{ The Global Real Estate Investment Attractiveness Index } \\
\hline 1. & \multicolumn{5}{|c|}{ Economic Activity } \\
\hline 1.1. & $\begin{array}{l}\text { Economic } \\
\text { Size }\end{array}$ & $\begin{array}{l}\text { [LN USD } \\
\mathrm{mn}]\end{array}$ & + & $\begin{array}{l}\text { The Economic Size of a country is measured by its } \\
\text { Gross domestic product (GDP) which is the sum of } \\
\text { gross value added by all resident producers in the } \\
\text { economy plus any product taxes and minus any } \\
\text { subsidies not included in the value of the products. } \\
\text { It is calculated without making deductions for } \\
\text { depreciation of fabricated assets or for depletion } \\
\text { and degradation of natural resources. }\end{array}$ & $\begin{array}{l}\text { Euromonitor } \\
\text { International from } \\
\text { International Monetary } \\
\text { Fund (IMF), } \\
\text { International Financial } \\
\text { Statistics }\end{array}$ \\
\hline 1.2. & $\begin{array}{l}\text { GDP per } \\
\text { capita }\end{array}$ & $\begin{array}{l}\text { ['000 } \\
\text { USD per } \\
\text { capita] }\end{array}$ & + & $\begin{array}{l}\text { Find definition above (Economic Size 1.1). "Per } \\
\text { Capita" describes the division of each data point by } \\
\text { the corresponding size of the country's population } \\
\text { (e.g. Finland's GDP in } 2004 \text { divided by the size of } \\
\text { its population in that year). }\end{array}$ & $\begin{array}{l}\text { Euromonitor International } \\
\text { from International } \\
\text { Monetary Fund (IMF), } \\
\text { International Financial } \\
\text { Statistics }\end{array}$ \\
\hline 1.3. & $\begin{array}{l}\text { Real GDP } \\
\text { Growth }\end{array}$ & [\%] & + & $\begin{array}{l}\text { 3-year historic geometric mean. } \\
\text { Gross domestic product is the sum of gross value }\end{array}$ & $\begin{array}{l}\text { Euromonitor } \\
\text { International from }\end{array}$ \\
\hline
\end{tabular}




\begin{tabular}{|c|c|c|c|c|c|}
\hline$\#$ & Name & Unit & Impact & Description & Source \\
\hline & & & & $\begin{array}{l}\text { added by all resident producers in the economy } \\
\text { plus any product taxes and minus any subsidies not } \\
\text { included in the value of the products. It is calculated } \\
\text { without making deductions for depreciation of } \\
\text { fabricated assets or for depletion and degradation } \\
\text { of natural resources. Real GDP: The number } \\
\text { reached by valuing all the productive activity within } \\
\text { the country at a specific year's prices. When } \\
\text { economic activity of two or more time periods is } \\
\text { valued at the same year's prices, the resulting } \\
\text { figure allows comparison of purchasing power over } \\
\text { time, since the effects of inflation have been } \\
\text { removed by maintaining constant prices. }\end{array}$ & $\begin{array}{l}\text { International Monetary } \\
\text { Fund (IMF), } \\
\text { International Financial } \\
\text { Statistics and World } \\
\text { Economic } \\
\text { Outlook/UN/national } \\
\text { statistics }\end{array}$ \\
\hline 1.4. & $\begin{array}{l}\text { Unemployment } \\
\text { Rate }\end{array}$ & [\%] & - & $\begin{array}{l}\text { Unemployment rate: the ILO international standard } \\
\text { definition of unemployment is based on the } \\
\text { following three criteria which should be satisfied } \\
\text { simultaneously: "without work," "currently available } \\
\text { for work" and "seeking work." }\end{array}$ & $\begin{array}{l}\text { Euromonitor } \\
\text { International from } \\
\text { International Labour } \\
\text { Organization }\end{array}$ \\
\hline 1.5. & $\begin{array}{l}\text { Inflation, } \\
\text { Average } \\
\text { Consumer } \\
\text { Prices }\end{array}$ & {$[\%]$} & - & $\begin{array}{l}\text { The annual average inflation rate indicates the } \\
\text { average percentage increase in the price of goods } \\
\text { and services comparing every month of the year } \\
\text { with the corresponding month last year. Data are } \\
\text { averages for the year, not end-of-period data. }\end{array}$ & $\begin{array}{l}\text { International Monetary } \\
\text { Fund }\end{array}$ \\
\hline 1.6. & $\begin{array}{l}\text { General } \\
\text { Innovativeness } \\
\text { Index }\end{array}$ & {$[-]$} & + & $\begin{array}{l}\text { The framework groups the eight pillars of } \\
\text { innovation into two categories: Inputs and Outputs. } \\
\text { The five Input pillars - Institutions and Policies, } \\
\text { Human Capacity, Infrastructure, Technological } \\
\text { Sophistication and Business Markets and Capital - } \\
\text { represent aspects which enhance a nation's } \\
\text { capacity to generate ideas and leverage them for } \\
\text { innovative products and services. The three Output } \\
\text { pillars - Knowledge, Competitiveness, and Wealth } \\
\text { - represent the ultimate benefits of innovation for a } \\
\text { nation - more knowledge creation, increased } \\
\text { competitiveness and greater wealth generation. } \\
\text { Each pillar of the Gll model is measured by a } \\
\text { number of quantitative and qualitative variables. } \\
\text { The averaged scores for the Input and Output } \\
\text { pillars together give an overall score - the Global } \\
\text { Innovation Index. The values of each variable for } \\
\text { the country are scaled on a range of } 1 \text { to } 7 \text {. }\end{array}$ & INSEAD \\
\hline 2. & \multicolumn{5}{|c|}{ Real Estate Investment Opportunities } \\
\hline 2.1. & $\begin{array}{l}\text { Institutional } \\
\text { Property } \\
\text { Estimation }\end{array}$ & $\begin{array}{l}\text { [LN USD } \\
\mathrm{mn}]\end{array}$ & + & $\begin{array}{l}\text { Approach according to Liang and Gordon }(2003) \text {, } \\
\text { which relates the size of a country's real estate } \\
\text { market to a country's GDP. } \\
R E=45 \%{ }^{*}{ }^{*} P^{\star}\left(G D P \_c a p i t a / 20000\right)^{\wedge}(-3) \text { for GDP < } \\
20000 \\
R E=45 \%{ }^{*} \text { GDP }\end{array}$ & $\begin{array}{l}\text { Euromonitor } \\
\text { International from } \\
\text { International Monetary } \\
\text { Fund (IMF), } \\
\text { International Financial } \\
\text { Statistics }\end{array}$ \\
\hline 2.2 . & $\begin{array}{l}\text { Degree of } \\
\text { Urbanization }\end{array}$ & & & & \\
\hline 2.2.1. & $\begin{array}{l}\text { Agglomeration } \\
\text { Poles }\end{array}$ & [number] & + & $\begin{array}{l}\text { Number of urban agglomerations with more than } \\
1 \text { million inhabitants }\end{array}$ & $\begin{array}{l}\text { United Nations } \\
\text { (http://www.mongabay.c } \\
\text { om/igapo/2005_world_ci } \\
\text { ty_populations/2005_urb } \\
\text { an_01.html) }\end{array}$ \\
\hline
\end{tabular}




\begin{tabular}{|c|c|c|c|c|c|}
\hline$\#$ & Name & Unit & Impact & Description & Source \\
\hline 2.2 .2 . & $\begin{array}{l}\text { Housing } \\
\text { stock }\end{array}$ & [LN ‘000] & + & $\begin{array}{l}\text { Refers to the stock of permanent dwellings. A } \\
\text { dwelling is a self-contained unit of accommodation. } \\
\text { Self-containment is where all the rooms (in } \\
\text { particular, the basic facilities i.e. kitchen, bathroom } \\
\text { and toilet) are behind a door that only the } \\
\text { household can use. A dwelling can therefore } \\
\text { contain a single household or a number of } \\
\text { households, which share at least one of the basic } \\
\text { facilities but do not share living accommodation. A } \\
\text { permanent dwelling relates to a building whose } \\
\text { structure should satisfy at least one of the following } \\
\text { criteria: - the walls are of brick, stone and mortar, } \\
\text { concrete, breeze block, or similar material; - the } \\
\text { roof is of ceramic tiles, slate, thatch, shingle, or } \\
\text { concrete; - the length of the shortest wall is least } \\
15 \text { feet - it has a life span of over } 60 \text { years. }\end{array}$ & $\begin{array}{l}\text { Euromonitor (GMID), } \\
\text { National Statistics }\end{array}$ \\
\hline 2.3 . & $\begin{array}{l}\text { Urban } \\
\text { Population }\end{array}$ & & & & \\
\hline 2.3.1. & $\begin{array}{l}\text { Urban } \\
\text { Population }\end{array}$ & $\begin{array}{l}{[\% \text { of }} \\
\text { Population } \\
]\end{array}$ & + & $\begin{array}{l}\text { Urban population is the population of areas defined } \\
\text { as urban in each country and reported to the United } \\
\text { Nations. }\end{array}$ & $\begin{array}{l}\text { Euromonitor } \\
\text { International }\end{array}$ \\
\hline 2.3.2. & $\begin{array}{l}\text { Urban } \\
\text { Population } \\
\text { Growth } \\
\end{array}$ & {$[\%]$} & + & 3-year geometric mean. & $\begin{array}{l}\text { Euromonitor } \\
\text { International }\end{array}$ \\
\hline 2.4 . & \begin{tabular}{|l|} 
Quality of \\
Infrastructure
\end{tabular} & & & & \\
\hline 2.4.1. & $\begin{array}{l}\text { Density of } \\
\text { road network }\end{array}$ & {$\left[\begin{array}{l}{[\mathrm{km} \text { per } \mathrm{sp}} \\
\mathrm{km} \text { of land] }\end{array}\right.$} & + & $\begin{array}{l}\text { Total length, in kilometres, of motorways, } \\
\text { highways } / \text { main/national roads, secondary/regional } \\
\text { roads and other roads, divided by the area of the } \\
\text { country in sq km. }\end{array}$ & $\begin{array}{l}\text { Euromonitor } \\
\text { International }\end{array}$ \\
\hline 2.4 .2 & $\begin{array}{l}\text { Quality of road } \\
\text { infrastructure }\end{array}$ & {$[-]$} & + & $\begin{array}{l}\text { Roads in your country are }(1=\text { underdeveloped, } 7= \\
\text { extensive and efficient by international standards })\end{array}$ & $\begin{array}{l}\text { World Economic Forum } \\
2008-2009\end{array}$ \\
\hline 2.4.3. & $\begin{array}{l}\text { Quality of } \\
\text { railroad } \\
\text { infrastructure } \\
\end{array}$ & {$[-]$} & + & $\begin{array}{l}\text { Railroads in your country are }(1=\text { underdeveloped, } \\
7=\text { extensive and efficient by international } \\
\text { standards). }\end{array}$ & $\begin{array}{l}\text { World Economic Forum } \\
2008-2009\end{array}$ \\
\hline 2.4.4. & $\begin{array}{l}\text { Quality of air } \\
\text { transport } \\
\text { infrastructure }\end{array}$ & {$[-]$} & + & $\begin{array}{l}\text { Passenger air transport in your country is ( } 1= \\
\text { underdeveloped, } 7=\text { extensive and efficient by } \\
\text { international standards). }\end{array}$ & $\begin{array}{l}\text { World Economic Forum } \\
2008-2009\end{array}$ \\
\hline 2.4 .5 & $\begin{array}{l}\text { Quality of } \\
\text { electricity } \\
\text { supply }\end{array}$ & {$[-]$} & + & $\begin{array}{l}\text { The quality of the electricity supply in your country } \\
\text { (lack of interruptions and lack of voltage fluctuations) } \\
\text { ( } 1=\text { is worse than in most other countries, } 7 \text { = meets } \\
\text { the highest standards in the world). }\end{array}$ & $\begin{array}{l}\text { World Economic Forum } \\
2008-2009\end{array}$ \\
\hline 2.4.6. & $\begin{array}{l}\text { Telecommu- } \\
\text { nication }\end{array}$ & [per capita] & + & $\begin{array}{l}\text { Telephone mainlines are fixed telephone lines } \\
\text { connecting a subscriber to the telephone exchange } \\
\text { equipment. }\end{array}$ & $\begin{array}{l}\text { World Development } \\
\text { Indicators }\end{array}$ \\
\hline 2.5 . & $\begin{array}{l}\text { Services } \\
\text { Total Output }\end{array}$ & {$\left[\begin{array}{l}{[\% \text { of }} \\
\text { GDP }]\end{array}\right.$} & + & $\begin{array}{l}\text { Services correspond to ISIC divisions 50-99. They } \\
\text { include value added in wholesale and retail trade } \\
\text { (including hotels and restaurants), transport, and } \\
\text { government, financial, professional, and personal } \\
\text { services such as education, health care, and real } \\
\text { estate services. Also included are imputed bank } \\
\text { service charges, import duties, and any statistical } \\
\text { discrepancies noted by national compilers as well } \\
\text { as discrepancies arising from rescaling. Value } \\
\text { added is the net output of a sector after adding up }\end{array}$ & $\begin{array}{l}\text { World Development } \\
\text { Indicators }\end{array}$ \\
\hline
\end{tabular}




\begin{tabular}{|c|c|c|c|c|c|}
\hline$\#$ & Name & Unit & Impact & Description & Source \\
\hline & & & & $\begin{array}{l}\text { all outputs and subtracting intermediate inputs. It is } \\
\text { calculated without making deductions for } \\
\text { depreciation of fabricated assets or depletion and } \\
\text { degradation of natural resources. The industrial } \\
\text { origin of value added is determined by the } \\
\text { International Standard Industrial Classification (ISIC), } \\
\text { revision 3. Data are in current United States dollars. }\end{array}$ & \\
\hline 3. & \multicolumn{5}{|c|}{ Depth of Capital Market } \\
\hline 3.1. & $\begin{array}{l}\text { Size and } \\
\text { Liquidity of } \\
\text { the Stock } \\
\text { Market }\end{array}$ & & & & \\
\hline 3.1 .1 & $\begin{array}{l}\text { Stock Market } \\
\text { Capitalization }\end{array}$ & $\begin{array}{l}\text { [LN USD } \\
\mathrm{mn}]\end{array}$ & + & $\begin{array}{l}\text { Market capitalization is the share price times the } \\
\text { number of shares outstanding. Listed domestic } \\
\text { companies are the domestically incorporated } \\
\text { companies listed on the country's stock exchanges } \\
\text { at the end of the year. Listed companies does not } \\
\text { include investment companies, mutual funds, or } \\
\text { other collective investment vehicles. }\end{array}$ & $\begin{array}{l}\text { Euromonitor } \\
\text { International from } \\
\text { International Monetary } \\
\text { Fund (IMF), } \\
\text { International Financial } \\
\text { Statistics }\end{array}$ \\
\hline 3.1.2. & $\begin{array}{l}\text { Total Trading } \\
\text { Volume }\end{array}$ & {$[\%$ of } & + & $\begin{array}{l}\text { This refers to the total value traded during one } \\
\text { period. }\end{array}$ & $\begin{array}{l}\text { World Bank (World } \\
\text { Development Indicator) }\end{array}$ \\
\hline 3.2 . & $\begin{array}{l}\text { IPO Market } \\
\text { Activity }\end{array}$ & & & & \\
\hline 3.2.1. & $\begin{array}{l}\text { IPO Market } \\
\text { Volume }\end{array}$ & $\begin{array}{l}\text { [LN USD } \\
\mathrm{mn}]\end{array}$ & + & $\begin{array}{l}\text { Proceeds Amount }+ \text { Overallotment sold in this } \\
\text { Market: } \\
\text { This data series shows the proceeds amount of the } \\
\text { issue in this market plus the overallotment amount } \\
\text { (a.k.a. green shoe) sold in this market; i.e. number } \\
\text { of shares in this market plus the overallotment } \\
\text { shares sold in this market multiplied by the offer } \\
\text { price. A green shoe clause in an underwriting } \\
\text { agreement provides that, in the case of excess } \\
\text { demand, the issuer will authorize additional shares } \\
\text { to be sold through the existing syndicate. }\end{array}$ & Thomson One Banker \\
\hline 3.2.2. & $\begin{array}{l}\text { Number of } \\
\text { IPOs }\end{array}$ & [LN ‘000] & + & Number of Initial Public Offers (IPOs) in a country. & Thomson One Banker \\
\hline 3.3. & $\begin{array}{l}\text { M\&A Market } \\
\text { Activity }\end{array}$ & & & & \\
\hline 3.3.1. & $\begin{array}{l}\text { M\&A Market } \\
\text { Volume }\end{array}$ & $\begin{array}{l}\text { [LN USD } \\
\mathrm{mn}]\end{array}$ & + & $\begin{array}{l}\text { The data comprise M\&A Ranking Value incl. Net Debt of } \\
\text { Target: } \\
\text { According to Thomson: RANKVAL = VALNOLIA + } \\
\text { Straight Debt + Short - term Debt + Preferred Equity - } \\
\text { Cash; VALNOLIA: Transaction Value Excluding } \\
\text { Liabilities Assumed; Transaction Value minus the value } \\
\text { of any liabilities agreed to be assumed in the transaction. }\end{array}$ & Thomson One Banker \\
\hline 3.3.2. & $\begin{array}{l}\text { Number of } \\
\text { Deals }\end{array}$ & [LN ‘000] & + & Number of M\&A deals in a country. & Thomson One Banker \\
\hline 3.4 . & $\begin{array}{l}\text { Debt and } \\
\text { Credit Market }\end{array}$ & & & & \\
\hline 3.4.1. & $\begin{array}{l}\text { Domestic } \\
\text { Credit } \\
\text { provided by } \\
\text { Banking } \\
\text { Sector }\end{array}$ & {$\left[\begin{array}{l}\text { [\% of } \\
\text { GDP }]\end{array}\right.$} & + & $\begin{array}{l}\text { Domestic credit provided by the banking sector } \\
\text { includes all credit to various sectors on a gross } \\
\text { basis, with the exception of credit to the central } \\
\text { government, which is net. The banking sector } \\
\text { includes monetary authorities and deposit money } \\
\text { banks, as well as other banking institutions where }\end{array}$ & $\begin{array}{l}\text { World Bank (World } \\
\text { Development Indicator) }\end{array}$ \\
\hline
\end{tabular}




\begin{tabular}{|c|c|c|c|c|c|}
\hline$\#$ & Name & Unit & Impact & Description & Source \\
\hline & & & & $\begin{array}{l}\text { data are available (including institutions that do not } \\
\text { accept transferable deposits but do incur such } \\
\text { liabilities as time and savings deposits). Examples } \\
\text { of other banking institutions are savings and } \\
\text { mortgage loan institutions and building and loan } \\
\text { associations. }\end{array}$ & \\
\hline 3.4.2. & $\begin{array}{l}\text { Ease of } \\
\text { Access to } \\
\text { Loans }\end{array}$ & {$[-]$} & + & $\begin{array}{l}\text { This data series measures the perceived simplicity } \\
\text { of obtaining a bank loan in a country with only a } \\
\text { good business plan and no collateral. }\end{array}$ & $\begin{array}{l}\text { World Economic Forum, } \\
\text { Executive Opinion } \\
\text { Survey } 2007,2008\end{array}$ \\
\hline 3.4.3. & $\begin{array}{l}\text { Credit } \\
\text { Information } \\
\text { Index }\end{array}$ & {$[-]$} & + & $\begin{array}{l}\text { The index ranges from } 0 \text { to } 6 \text {, with higher values } \\
\text { indicating the availability of more credit information, } \\
\text { from either a public registry or a private bureau, to } \\
\text { facilitate lending decisions. If the registry is not } \\
\text { operational or has coverage of less than } 0.1 \% \text { of } \\
\text { the adult population, the score on the depth of } \\
\text { credit information index is } 0 \text {. } \\
\text { The depth of credit information index measures } \\
\text { rules affecting the scope, accessibility and quality } \\
\text { of credit information available through either public } \\
\text { or private credit registries. A score of } 1 \text { is assigned } \\
\text { for each of the following } 6 \text { features of the public } \\
\text { registry or the private credit bureau (or both). }\end{array}$ & $\begin{array}{l}\text { World Bank (Doing } \\
\text { Business Database) }\end{array}$ \\
\hline 3.4.4. & $\begin{array}{l}\text { Soundness of } \\
\text { Banks }\end{array}$ & {$[-]$} & + & $\begin{array}{l}\text { This data series measures the perceived } \\
\text { "Soundness of Banks" Banks in a country. The } \\
\text { index ranges from } 1 \text { to } 7 \text {, with higher values } \\
\text { indicating that banks are generally healthy with } \\
\text { sound balance sheets and low values indicating } \\
\text { that banks are in danger of insolvency and may } \\
\text { require a government bailout. }\end{array}$ & $\begin{array}{l}\text { World Economic Forum } \\
\text { (Executive Opinion } \\
\text { Survey 2007, 2008) }\end{array}$ \\
\hline 3.4.5. & $\begin{array}{l}\text { Interest Rate } \\
\text { Spread }\end{array}$ & {$[\%]$} & - & $\begin{array}{l}\text { Interest rate spread is the interest rate charged by } \\
\text { banks on loans to prime customers minus the } \\
\text { interest rate paid by commercial or similar banks for } \\
\text { demand, time, or savings deposits. }\end{array}$ & $\begin{array}{l}\text { World Economic Forum; } \\
\text { IMF; Economist } \\
\text { Intelligence Unit (June } \\
\text { 2008); World } \\
\text { Development Indicators } \\
2008\end{array}$ \\
\hline 3.4.6. & $\begin{array}{l}\text { Bank Non- } \\
\text { performing } \\
\text { Loans to } \\
\text { Total Gross } \\
\text { Loans }\end{array}$ & {$[\%]$} & - & $\begin{array}{l}\text { Bank non-performing loans to total gross loans are } \\
\text { the value of non-performing loans divided by the } \\
\text { total value of the loan portfolio (including non- } \\
\text { performing loans before the deduction of specific } \\
\text { loan-loss provisions). The loan amount recorded as } \\
\text { non-performing should be the gross value of the } \\
\text { loan as recorded on the balance sheet, not just the } \\
\text { amount that is overdue. }\end{array}$ & $\begin{array}{l}\text { World Bank (World } \\
\text { Development Indicator) }\end{array}$ \\
\hline 3.5 . & $\begin{array}{l}\text { Access to } \\
\text { Private } \\
\text { Capital }\end{array}$ & & & & \\
\hline 3.5.1. & $\begin{array}{l}\text { Foreign } \\
\text { Direct } \\
\text { Investment, } \\
\text { Net Inflows } \\
\end{array}$ & $\begin{array}{l}\text { [LN USD } \\
\mathrm{mn}]\end{array}$ & + & $\begin{array}{l}\text { Inflows of FDI in the reporting economy comprise } \\
\text { capital provided (either directly or through other } \\
\text { related enterprises) by a foreign direct investor to an } \\
\text { enterprise resident in the economy (FDI enterprise). }\end{array}$ & $\begin{array}{l}\text { Euromonitor } \\
\text { International from } \\
\text { UNCTAD }\end{array}$ \\
\hline 3.5.2. & $\begin{array}{l}\text { Private } \\
\text { Equity } \\
\text { Investments }\end{array}$ & $\begin{array}{l}\text { [LN USD } \\
\mathrm{mn}]\end{array}$ & + & $\begin{array}{l}\text { Amount of private equity investments in a country } \\
\text { per year. The country is defined by fund location. } \\
\text { Thomson Reuters uses the term to describe the } \\
\text { universe of all venture investing, buyout investing } \\
\text { and mezzanine investing. }\end{array}$ & Thomson One Banker \\
\hline
\end{tabular}




\begin{tabular}{|c|c|c|c|c|c|}
\hline \# & Name & Unit & Impact & Description & Source \\
\hline 3.6. & $\begin{array}{l}\text { REITs Market } \\
\text { Volume }\end{array}$ & $\begin{array}{l}{[\text { LN USD }} \\
\mathrm{mn}]\end{array}$ & + & $\begin{array}{l}\text { Specifies the market volume of real estate } \\
\text { investment trusts listed in the country. However, } \\
\text { investment exposure can differ from the country } \\
\text { incorporation. }\end{array}$ & $\begin{array}{l}\text { FTSE EPRA NAREIT } \\
\text { Series }\end{array}$ \\
\hline 4. & \multicolumn{5}{|c|}{ Investor Protection and Legal Framework } \\
\hline 4.1. & $\begin{array}{l}\text { Investor } \\
\text { Protection }\end{array}$ & & & & \\
\hline 4.1.1. & $\begin{array}{l}\text { Disclosure } \\
\text { Index }\end{array}$ & {$[-]$} & + & $\begin{array}{l}\text { The index ranges from } 0 \text { to } 10 \text {, with higher values } \\
\text { indicating greater disclosure. }\end{array}$ & $\begin{array}{l}\text { World Bank (Doing } \\
\text { Business Database) }\end{array}$ \\
\hline 4.1 .2$. & \begin{tabular}{|l|} 
Director \\
Liability Index \\
\end{tabular} & {$[-]$} & + & $\begin{array}{l}\text { The index ranges from } 0 \text { to } 10 \text {, with higher values } \\
\text { indicating greater liability of directors. }\end{array}$ & $\begin{array}{l}\text { World Bank (Doing } \\
\text { Business Database) } \\
\end{array}$ \\
\hline 4.1.3. & $\begin{array}{l}\text { Shareholder } \\
\text { Suits Index }\end{array}$ & {$[-]$} & + & $\begin{array}{l}\text { The index ranges from } 0 \text { to } 10 \text {, with higher values } \\
\text { indicating greater powers of shareholders to } \\
\text { challenge the transaction. }\end{array}$ & $\begin{array}{l}\text { World Bank (Doing } \\
\text { Business Database) }\end{array}$ \\
\hline 4.2. & $\begin{array}{l}\text { Security of } \\
\text { Property } \\
\text { Rights }\end{array}$ & & & & \\
\hline 4.2.1. & $\begin{array}{l}\text { Legal Rights } \\
\text { Index }\end{array}$ & {$[-]$} & + & $\begin{array}{l}\text { The index ranges from } 0 \text { to } 10 \text {, with higher scores } \\
\text { indicating that collateral and bankruptcy laws are } \\
\text { better designed to expand access to credit. The } \\
\text { legal rights index measures the degree to which } \\
\text { collateral and bankruptcy laws protect the rights of } \\
\text { borrowers and lenders and thus facilitate lending. }\end{array}$ & $\begin{array}{l}\text { World Bank (Doing } \\
\text { Business Database) }\end{array}$ \\
\hline 4.2.2. & $\begin{array}{l}\text { Property } \\
\text { Rights }\end{array}$ & {$[-]$} & + & $\begin{array}{l}\text { "Property rights" is an assessment of the ability of } \\
\text { individuals to accumulate private property, secured } \\
\text { by clear laws that are fully enforced by the state. }\end{array}$ & Heritage Foundation \\
\hline 4.3. & $\begin{array}{l}\text { Quality of } \\
\text { Legal } \\
\text { Enforcement }\end{array}$ & & & & \\
\hline 4.3.1. & $\begin{array}{l}\text { Judicial } \\
\text { Independence }\end{array}$ & {$[-]$} & + & $\begin{array}{l}\text { This data series measures the perceived "Judicial } \\
\text { Independence" in a country. The index ranges from } 0 \\
\text { to } 7 \text {, with higher values indicating that the judiciary in } \\
\text { a country is independent from political influences of } \\
\text { members of government, citizens, or firms and lower } \\
\text { values indicating that it is heavily influenced. }\end{array}$ & $\begin{array}{l}\text { Fraser Institute } \\
\text { World Economic Forum } \\
\text { (Global Competitiveness } \\
\text { Report) }\end{array}$ \\
\hline 4.3.2. & $\begin{array}{l}\text { Integrity of } \\
\text { the Legal } \\
\text { System }\end{array}$ & {$[-]$} & + & $\begin{array}{l}\text { This component is based on two sub-components. } \\
\text { Each sub-component equals half of the total. The } \\
\text { 'law' sub-component assesses the strength and } \\
\text { impartiality of the legal system, and the 'order' sub- } \\
\text { component assesses popular observance of the } \\
\text { law. The index ranges from } 0 \text { to } 10 \text {. High rating } \\
\text { values indicate a sound legal system. }\end{array}$ & $\begin{array}{l}\text { Fraser Institute, } \\
\text { PRS Group } \\
\text { (International Country } \\
\text { Risk Guide) }\end{array}$ \\
\hline 4.3.3. & Rule of Law & {$[-]$} & + & $\begin{array}{l}\text { "Rule of Law" measures the extent to which agents } \\
\text { have confidence in and abide by the rules of } \\
\text { society, in particular the quality of contract } \\
\text { enforcement, the police, and the courts, as well as } \\
\text { the likelihood of crime and violence. The index } \\
\text { ranges from } 0 \text { to } 100 \text {. }\end{array}$ & $\begin{array}{l}\text { World Bank (Worldwide } \\
\text { Governance Indicator) }\end{array}$ \\
\hline 4.4 . & $\begin{array}{l}\text { Regulatory } \\
\text { Quality }\end{array}$ & {$[-]$} & & $\begin{array}{l}\text { "Regulatory Quality" measures the ability of the } \\
\text { government to formulate and implement sound } \\
\text { policies and regulations that permit and promote } \\
\text { private sector development. The index ranges from } \\
0 \text { to } 100 \text {. }\end{array}$ & $\begin{array}{l}\text { World Bank (Worldwide } \\
\text { Governance Indicator) }\end{array}$ \\
\hline 5. & Administrativ & e Burdens & nd Regul & ory Limitations & \\
\hline 5.1. & Taxation & & & & \\
\hline
\end{tabular}




\begin{tabular}{|c|c|c|c|c|c|}
\hline$\#$ & Name & Unit & Impact & Description & Source \\
\hline 5.1.1. & $\begin{array}{l}\text { Marginal } \\
\text { Corporate } \\
\text { Tax Rate }\end{array}$ & [\%] & - & $\begin{array}{l}\text { Highest marginal tax rate (corporate rate) is the } \\
\text { highest rate shown on the schedule of tax rates } \\
\text { applied to the taxable income of corporations. } \\
\text { PricewaterhouseCoopers, Corporate Taxes: } \\
\text { Worldwide Summaries, by permission of John } \\
\text { Wiley and Sons, Inc. }\end{array}$ & $\begin{array}{l}\text { World Development } \\
\text { Indicators }\end{array}$ \\
\hline 5.1.2. & $\begin{array}{l}\text { Profit and } \\
\text { Capital Gains } \\
\text { Tax }\end{array}$ & [\%] & - & $\begin{array}{l}\text { Taxes on income, profits, and capital gains are } \\
\text { levied on the actual or presumptive net income of } \\
\text { individuals, on the profits of corporations and } \\
\text { enterprises, and on capital gains, whether realized } \\
\text { or not, on land, securities, and other assets. } \\
\text { Intergovernmental payments are eliminated in } \\
\text { consolidation. }\end{array}$ & $\begin{array}{l}\text { World Development } \\
\text { Indicators }\end{array}$ \\
\hline 5.2 . & $\begin{array}{l}\text { Burden } \\
\text { Getting a } \\
\text { Construction } \\
\text { Permit }\end{array}$ & {$[-]$} & & $\begin{array}{l}\text { This topic tracks the procedures, time, and costs to } \\
\text { build a warehouse, including obtaining necessary } \\
\text { licenses and permits, completing required } \\
\text { notifications and inspections, and obtaining utility } \\
\text { connections. } \\
\text { i) all procedures to build a warehouse; ii) average } \\
\text { time spent during each procedure, and iii) official } \\
\text { cost of each procedure. }\end{array}$ & $\begin{array}{l}\text { World Bank (Doing } \\
\text { Business Database) }\end{array}$ \\
\hline 5.2.1. & Costs & $\begin{array}{l}{[\% \text { of }} \\
\text { income } \\
\text { per } \\
\text { capita] }\end{array}$ & - & $\begin{array}{l}\text { A procedure is any interaction of the company's } \\
\text { employees or managers with external parties, } \\
\text { including government agencies, notaries, the land } \\
\text { registry, the cadastre, utility companies, public and } \\
\text { private inspectors and technical experts apart from } \\
\text { in-house architects and engineers. Interactions } \\
\text { between company employees, such as } \\
\text { development of the warehouse plans and } \\
\text { inspections conducted by employees, are not } \\
\text { counted as procedures. Procedures that the } \\
\text { company undergoes to connect to electricity, water, } \\
\text { sewerage and phone services are included. All } \\
\text { procedures that are legally or in practice required } \\
\text { for building a warehouse are counted, even if they } \\
\text { may be avoided in exceptional cases. }\end{array}$ & $\begin{array}{l}\text { World Bank (Doing } \\
\text { Business Database) }\end{array}$ \\
\hline 5.2.2. & $\begin{array}{l}\text { Number of } \\
\text { Procedures }\end{array}$ & [number] & - & $\begin{array}{l}\text { Cost is recorded as a percentage of the country's } \\
\text { income per capita. Only official costs are recorded. } \\
\text { All the fees associated with completing the } \\
\text { procedures to legally build a warehouse are } \\
\text { recorded, including those associated with obtaining } \\
\text { land use approvals and preconstruction design } \\
\text { clearances; receiving inspections before, during } \\
\text { and after construction; getting utility connections; } \\
\text { and registering the warehouse property. Non- } \\
\text { recurring taxes required for completion of the } \\
\text { warehouse project are also recorded. The building } \\
\text { code, information from local experts and specific } \\
\text { regulations and fee schedules are used as sources } \\
\text { for costs. If several local partners provide different } \\
\text { estimates, the median reported value is used. }\end{array}$ & $\begin{array}{l}\text { World Bank (Doing } \\
\text { Business Database) }\end{array}$ \\
\hline 5.2.3. & Duration & [days] & - & $\begin{array}{l}\text { Time is recorded in calendar days. The measure } \\
\text { captures the median duration that local experts } \\
\text { indicate is necessary to complete a procedure in } \\
\text { practice. It is assumed that the minimum time } \\
\text { required for each procedure is } 1 \text { day. If a procedure }\end{array}$ & $\begin{array}{l}\text { World Bank (Doing } \\
\text { Business Database) }\end{array}$ \\
\hline
\end{tabular}

36 - IESE Business School-University of Navarra 


\begin{tabular}{|c|c|c|c|c|c|}
\hline$\#$ & Name & Unit & Impact & Description & Source \\
\hline & & & & $\begin{array}{l}\text { can be accelerated legally for an additional cost, } \\
\text { the fastest procedure is chosen. It is assumed that } \\
\text { the construction company does not waste time and } \\
\text { commits to completing each remaining procedure } \\
\text { without delay. The time that the construction } \\
\text { company spends on gathering information is } \\
\text { ignored. It is assumed that the construction } \\
\text { company is aware of all building requirements and } \\
\text { their sequence from the beginning. }\end{array}$ & \\
\hline 5.3. & $\begin{array}{l}\text { Ease of } \\
\text { Registering } \\
\text { Property }\end{array}$ & & & $\begin{array}{l}\text { This topic examines the steps, time, and cost } \\
\text { involved in registering property, assuming a } \\
\text { standardized case of an entrepreneur who wants to } \\
\text { purchase land and a building that is already } \\
\text { registered and free of title dispute. } \\
\text { The main indicators include: i) number of } \\
\text { procedures legally required to register property; ii) } \\
\text { time spent in completing the procedures, and iii) the } \\
\text { costs, such as fees, transfer taxes, stamp duties, } \\
\text { and any other payment to the property registry, } \\
\text { notaries, public agencies or lawyers. The cost is } \\
\text { expressed as a percentage of the property value, } \\
\text { assuming a property value of } 50 \text { times income per } \\
\text { capita. }\end{array}$ & $\begin{array}{l}\text { World Bank (Doing } \\
\text { Business Database) }\end{array}$ \\
\hline 5.3.1. & $\begin{array}{l}\text { Costs (incl. } \\
\text { Transfer } \\
\text { Taxes) }\end{array}$ & $\begin{array}{l}{[\% \text { of }} \\
\text { property } \\
\text { value] }\end{array}$ & - & $\begin{array}{l}\text { Cost is recorded as a percentage of the property } \\
\text { value, assumed to be equivalent to } 50 \text { times } \\
\text { income per capita. Only official costs required by } \\
\text { law are recorded, including fees, transfer taxes, } \\
\text { stamp duties and any other payment to the property } \\
\text { registry, notaries, public agencies or lawyers. Other } \\
\text { taxes, such as capital gains tax or value added tax, } \\
\text { are excluded from the cost measure. Both costs } \\
\text { borne by the buyer and those borne by the seller } \\
\text { are included. If cost estimates differ among } \\
\text { sources, the median reported value is used. }\end{array}$ & $\begin{array}{l}\text { World Bank (Doing } \\
\text { Business Database) }\end{array}$ \\
\hline 5.3.2. & $\begin{array}{l}\text { Number of } \\
\text { Procedures }\end{array}$ & [number] & - & $\begin{array}{l}\text { A procedure is defined as any interaction of the } \\
\text { buyer or the seller, their agents (if an agent is } \\
\text { legally or in practice required) or the property with } \\
\text { external parties, including government agencies, } \\
\text { inspectors, notaries and lawyers. Interactions } \\
\text { between company officers and employees are not } \\
\text { considered. All procedures that are legally or in } \\
\text { practice required for registering property are } \\
\text { recorded, even if they may be avoided in } \\
\text { exceptional cases. It is assumed that the buyer } \\
\text { follows the fastest legal option available and used } \\
\text { by the majority of property owners. Although the } \\
\text { buyer may use lawyers or other professionals } \\
\text { where necessary in the registration process, it is } \\
\text { assumed that it does not employ an outside } \\
\text { facilitator in the registration process unless legally } \\
\text { or in practice required to do so. }\end{array}$ & $\begin{array}{l}\text { World Bank (Doing } \\
\text { Business Database) }\end{array}$ \\
\hline 5.3.3. & Duration & [days] & - & $\begin{array}{l}\text { Time is recorded in calendar days. The measure } \\
\text { captures the median duration that property lawyers, } \\
\text { notaries or registry officials indicate is necessary to } \\
\text { complete a procedure. It is assumed that the } \\
\text { minimum time required for each procedure is } 1 \text { day. }\end{array}$ & $\begin{array}{l}\text { World Bank (Doing } \\
\text { Business Database) }\end{array}$ \\
\hline
\end{tabular}




\begin{tabular}{|c|c|c|c|c|c|}
\hline$\#$ & Name & Unit & Impact & Description & Source \\
\hline & & & & $\begin{array}{l}\text { Although procedures may take place } \\
\text { simultaneously, they cannot start on the same day. } \\
\text { It is assumed that the buyer does not waste time } \\
\text { and commits to completing each remaining } \\
\text { procedure without delay. If a procedure can be } \\
\text { accelerated for an additional cost, the fastest legal } \\
\text { procedure available and used by the majority of } \\
\text { property owners is chosen. If procedures can be } \\
\text { undertaken simultaneously, it is assumed that they } \\
\text { are. It is assumed that the parties involved are } \\
\text { aware of all regulations and their sequence from } \\
\text { the beginning. Time spent on gathering information } \\
\text { is not considered. }\end{array}$ & \\
\hline 5.4 . & $\begin{array}{l}\text { Ease of } \\
\text { Starting a } \\
\text { Business } \\
\end{array}$ & & & & \\
\hline 5.4.1. & $\begin{array}{l}\text { Number of } \\
\text { Procedures } \\
\text { to start a } \\
\text { Business }\end{array}$ & [\#] & - & $\begin{array}{l}\text { This data series provides the average number of } \\
\text { administrative procedures necessary to start a } \\
\text { business in a country. } \\
\text { A procedure is defined as any interaction of the } \\
\text { company founder with external parties (for } \\
\text { example, government agencies, lawyers, auditors } \\
\text { or notaries). Interactions between company } \\
\text { founders or company officers and employees are } \\
\text { not counted as procedures. Only procedures } \\
\text { required of all businesses are covered. Industry- } \\
\text { specific procedures are excluded. For example, } \\
\text { procedures to comply with environmental } \\
\text { regulations are included only when they apply to all } \\
\text { businesses conducting general commercial or } \\
\text { industrial activities. Procedures that the company } \\
\text { undergoes to connect to electricity, water, gas and } \\
\text { waste disposal services are not included. }\end{array}$ & $\begin{array}{l}\text { World Bank (Doing } \\
\text { Business) }\end{array}$ \\
\hline 5.4 .2 & $\begin{array}{l}\text { Time needed } \\
\text { to start a } \\
\text { Business }\end{array}$ & [Days] & - & $\begin{array}{l}\text { This data series provides the average number of days } \\
\text { necessary to start a business in a country. } \\
\text { Time is recorded in calendar days. The measure } \\
\text { captures the median duration that incorporation } \\
\text { lawyers indicate is necessary to complete a procedure } \\
\text { with minimum follow-up with government agencies } \\
\text { and no extra payments. It is assumed that the } \\
\text { minimum time required for each procedure is } 1 \text { day. }\end{array}$ & $\begin{array}{l}\text { World Bank (Doing } \\
\text { Business) }\end{array}$ \\
\hline 5.4.3. & $\begin{array}{l}\text { Cost of } \\
\text { Business } \\
\text { Start-Up } \\
\text { Procedures }\end{array}$ & $\begin{array}{l}{[\% \text { of }} \\
\text { Income } \\
\text { per } \\
\text { Capita] }\end{array}$ & - & $\begin{array}{l}\text { This data series provides the average amount of } \\
\text { money necessary to start a business in a country. } \\
\text { Cost is recorded as a percentage of the country's } \\
\text { income per capita. It includes all official fees and fees } \\
\text { for legal or professional services if such services are } \\
\text { required by law. Fees for purchasing and legalizing } \\
\text { company books are included if these transactions are } \\
\text { required by law. The cost excludes bribes. }\end{array}$ & $\begin{array}{l}\text { World Bank (Doing } \\
\text { Business) }\end{array}$ \\
\hline 5.4 .4 & Min. Capital & $\begin{array}{l}{[\% \text { of }} \\
\text { Income } \\
\text { per } \\
\text { Capita] }\end{array}$ & - & $\begin{array}{l}\text { The paid-in minimum capital requirement reflects } \\
\text { the amount that the entrepreneur needs to deposit } \\
\text { in a bank or with a notary before registration and up } \\
\text { to } 3 \text { months following incorporation and is recorded } \\
\text { as a percentage of the country's income per capita. } \\
\text { The amount is typically specified in the commercial } \\
\text { code or the company law. Many countries have a }\end{array}$ & $\begin{array}{l}\text { World Bank (Doing } \\
\text { Business) }\end{array}$ \\
\hline
\end{tabular}

38 - IESE Business School-University of Navarra 


\begin{tabular}{|c|c|c|c|c|c|}
\hline$\#$ & Name & Unit & Impact & Description & Source \\
\hline & & & & $\begin{array}{l}\text { minimum capital requirement but allow businesses } \\
\text { to pay only a part of it before registration, with the } \\
\text { rest to be paid after the first year of operation. }\end{array}$ & \\
\hline 5.5. & $\begin{array}{l}\text { Ease of } \\
\text { Closing a } \\
\text { Business }\end{array}$ & & & & \\
\hline 5.5.1. & Time & [Years] & - & $\begin{array}{l}\text { This data series provides the average number of } \\
\text { years necessary to close a business in a country. } \\
\text { Time is recorded in calendar years. Information is } \\
\text { collected on the sequence of procedures and on } \\
\text { whether any procedures can be carried out } \\
\text { simultaneously. Potential delaying tactics by the } \\
\text { parties, such as the filing of dilatory appeals or } \\
\text { requests for extension, are taken into consideration. }\end{array}$ & $\begin{array}{l}\text { World Bank (Doing } \\
\text { Business) }\end{array}$ \\
\hline 5.5.2. & Cost & $\begin{array}{l}{[\% \text { of }} \\
\text { Estate] }\end{array}$ & - & $\begin{array}{l}\text { This data series provides the average costs of } \\
\text { closing a business in a country. } \\
\text { The cost of the proceedings is recorded as a } \\
\text { percentage of the estate's value. The cost is } \\
\text { calculated on the basis of survey responses by } \\
\text { insolvency practitioners and includes court fees as } \\
\text { well as fees of insolvency practitioners, independent } \\
\text { assessors, lawyers and accountants. Respondents } \\
\text { provide cost estimates from among the following } \\
\text { options: less than } 2 \%, 2-5 \%, 5-8 \%, 8-11 \%, 11- \\
18 \%, 18-25 \%, 25-33 \%, 33-50 \%, 50-75 \% \text { and more } \\
\text { than } 75 \% \text { of the value of the business estate. }\end{array}$ & $\begin{array}{l}\text { World Bank (Doing } \\
\text { Business) }\end{array}$ \\
\hline 5.5.3. & $\begin{array}{l}\text { Recovery } \\
\text { Rate [Cents } \\
\text { on USD] }\end{array}$ & $\begin{array}{l}\text { [Cents } \\
\text { on USD] }\end{array}$ & + & $\begin{array}{l}\text { The recovery rate is recorded as cents on the dollar } \\
\text { recouped by creditors through the bankruptcy or } \\
\text { insolvency proceedings. The calculation takes into } \\
\text { account whether the business emerges from the } \\
\text { proceedings as a going concern as well as costs and } \\
\text { the loss in value due to the time spent closing down. } \\
\text { If the business keeps operating, no value is lost on } \\
\text { the initial claim, set at } 100 \text { cents on the dollar. If it } \\
\text { does not, the initial } 100 \text { cents on the dollar are } \\
\text { reduced to } 70 \text { cents on the dollar. Then the official } \\
\text { costs of the insolvency procedure are deducted } \\
\text { (1 cent for each percentage of the initial value). } \\
\text { Finally, the value lost as a result of the time the } \\
\text { money remains tied up in insolvency proceedings is } \\
\text { taken into account, including the loss of value due to } \\
\text { depreciation of the hotel furniture. Consistent with } \\
\text { international accounting practice, the depreciation } \\
\text { rate for furniture is taken to be } 20 \% \text {. The furniture is } \\
\text { assumed to account for a quarter of the total value of } \\
\text { assets. The recovery rate is the present value of the } \\
\text { remaining proceeds, based on end-2006 lending } \\
\text { rates from the International Monetary Fund's } \\
\text { International Financial Statistics, supplemented with } \\
\text { data from central banks. }\end{array}$ & $\begin{array}{l}\text { World Bank (Doing } \\
\text { Business) }\end{array}$ \\
\hline 5.6. & $\begin{array}{l}\text { Foreign } \\
\text { Exchange } \\
\text { Controls }\end{array}$ & {$[-]$} & + & $\begin{array}{l}\text { The Index evaluates a variety of restrictions } \\
\text { typically imposed on investment. Points, as } \\
\text { indicated below, are deducted from the ideal score } \\
\text { of } 100 \text { for each of the restrictions found in a } \\
\text { country's investment regime. It is not necessary for } \\
\text { a government to impose all of the listed restrictions }\end{array}$ & $\begin{array}{l}\text { Heritage Foundation } \\
\text { (Index of Economic } \\
\text { Freedom) }\end{array}$ \\
\hline
\end{tabular}




\begin{tabular}{|c|c|c|c|c|c|}
\hline$\#$ & Name & Unit & Impact & Description & Source \\
\hline & & & & $\begin{array}{l}\text { at the maximum level to effectively eliminate } \\
\text { investment freedom. The few governments that } \\
\text { impose so many restrictions that they total more } \\
\text { than } 100 \text { points in deductions have had their scores } \\
\text { set at zero. } \\
\text { Investment restrictions: } \\
\text { i) National treatment of foreign investment } \\
\text { ii) Foreign investment } \\
\text { iii) Restrictions on land ownership } \\
\text { iv) Sectoral investment restrictions } \\
\text { v) Expropriation of investments without fair } \\
\text { vi) Fompensation } \\
\text { vii) Capital controls and repatriation of profits }\end{array}$ & \\
\hline 6. & \multicolumn{5}{|c|}{ Socio-cultural and Political Environment } \\
\hline 6.1. & $\begin{array}{l}\text { Human } \\
\text { Development }\end{array}$ & {$[-]$} & + & $\begin{array}{l}\text { The Human Development Index (HDI) is an index } \\
\text { used to rank countries by level of "human } \\
\text { development." The HDI provides a composite } \\
\text { measure of three dimensions of human } \\
\text { development (best }=1 \text { / worst=0): living a long and } \\
\text { healthy life (measured by life expectancy), being } \\
\text { educated (measured by adult literacy and gross } \\
\text { enrolment in education) and having a decent } \\
\text { standard of living (measured by purchasing power } \\
\text { parity, PPP, income). } \\
\text { It is used to distinguish whether the country is a } \\
\text { developed, a developing or an under-developed } \\
\text { country, and also to measure the impact of } \\
\text { economic policies on quality of life. The index was } \\
\text { developed in } 1990 \text { by Pakistani economist Mahbub } \\
\text { ul Haq and Indian economist Amartya Sen. }\end{array}$ & $\begin{array}{l}\text { Human Development } \\
\text { Index: Euromonitor from } \\
\text { trade sources/national } \\
\text { statistics }\end{array}$ \\
\hline 6.2. & Crime & & & & \\
\hline 6.2.1. & $\begin{array}{l}\text { Business } \\
\text { Costs of } \\
\text { Crime and } \\
\text { Violence }\end{array}$ & {$[-]$} & + & $\begin{array}{l}\text { This data series measures the costs on businesses } \\
\text { imposed by the incidence of common crime and } \\
\text { violence in a country. The index ranges from } 1 \text { to } 7 \text {. } \\
\text { High values are assigned to countries where crime } \\
\text { does not impose significant costs on businesses. }\end{array}$ & $\begin{array}{l}\text { World Economic Forum, } \\
\text { Executive Opinion } \\
\text { Survey } 2007,2008\end{array}$ \\
\hline 6.2.2. & $\begin{array}{l}\text { Costs of } \\
\text { Organized } \\
\text { Crime }\end{array}$ & {$[-]$} & + & $\begin{array}{l}\text { This data series measures the perceived "Cost of } \\
\text { Organized Crime" in a country. The index ranges from } \\
1 \text { to } 7 \text { with higher values indicating that organized } \\
\text { crime (mafia-oriented racketeering, extortion) in a } \\
\text { country does not impose significant costs on } \\
\text { businesses. Lower values indicate that organized } \\
\text { crime imposes significant costs on businesses. }\end{array}$ & $\begin{array}{l}\text { World Economic Forum, } \\
\text { Executive Opinion } \\
\text { Survey 2007, } 2008\end{array}$ \\
\hline 6.3. & $\begin{array}{l}\text { Bribery and } \\
\text { Corruption }\end{array}$ & & & & \\
\hline 6.3.1. & $\begin{array}{l}\text { Bribery and } \\
\text { Corruption } \\
\text { Index }\end{array}$ & {$[-]$} & + & $\begin{array}{l}\text { This index describes the overall extent of corruption } \\
\text { (frequency and/or size of bribes) in the public and } \\
\text { political sectors. The index ranges from } 0 \text { to } 10 . \\
\text { Countries where bribery and corruption cases are } \\
\text { frequent receive a low rating score. }\end{array}$ & $\begin{array}{l}\text { Transparency } \\
\text { International }\end{array}$ \\
\hline 6.3.2. & $\begin{array}{l}\text { Control of } \\
\text { Corruption }\end{array}$ & {$[-]$} & + & $\begin{array}{l}\text { This data series measures the perception of the } \\
\text { extent to which public power is exercised for private } \\
\text { gain, including both petty and grand forms of } \\
\text { corruption, as well as "capture" of the state by elites }\end{array}$ & $\begin{array}{l}\text { World Bank (Worldwide } \\
\text { Governance Indicator) }\end{array}$ \\
\hline
\end{tabular}




\begin{tabular}{|c|c|c|c|c|c|}
\hline$\#$ & Name & Unit & Impact & Description & Source \\
\hline & & & & $\begin{array}{l}\text { and private interests. Countries in which seemingly } \\
\text { public power is frequently used for private gain } \\
\text { receive a low rating score. }\end{array}$ & \\
\hline 6.4 . & $\begin{array}{l}\text { Political } \\
\text { System }\end{array}$ & & & & \\
\hline 6.4.1. & $\begin{array}{l}\text { Voice and } \\
\text { Accountability }\end{array}$ & {$[-]$} & + & $\begin{array}{l}\text { The extent to which a country's citizens are able to } \\
\text { participate in selecting their government, as well as } \\
\text { freedom of expression, freedom of association, and } \\
\text { a free media. }\end{array}$ & $\begin{array}{l}\text { World Bank (Worldwide } \\
\text { Governance Indicator) }\end{array}$ \\
\hline 6.4.2. & $\begin{array}{l}\text { Political } \\
\text { Stability and } \\
\text { Absence of } \\
\text { Violence }\end{array}$ & {$[-]$} & + & $\begin{array}{l}\text { The likelihood that the government will be } \\
\text { destabilized by unconstitutional or violent means, } \\
\text { including terrorism. }\end{array}$ & $\begin{array}{l}\text { World Bank (Worldwide } \\
\text { Governance Indicator) }\end{array}$ \\
\hline 6.4.3. & $\begin{array}{l}\text { Government } \\
\text { Effectiveness }\end{array}$ & {$[-]$} & + & $\begin{array}{l}\text { The quality of public services, the capacity of the } \\
\text { civil service and its independence from political } \\
\text { pressures; and the quality of policy formulation. }\end{array}$ & $\begin{array}{l}\text { World Bank (Worldwide } \\
\text { Governance Indicator) }\end{array}$ \\
\hline
\end{tabular}




\section{Appendix B}

Correlation Matrix

\section{Correlations}

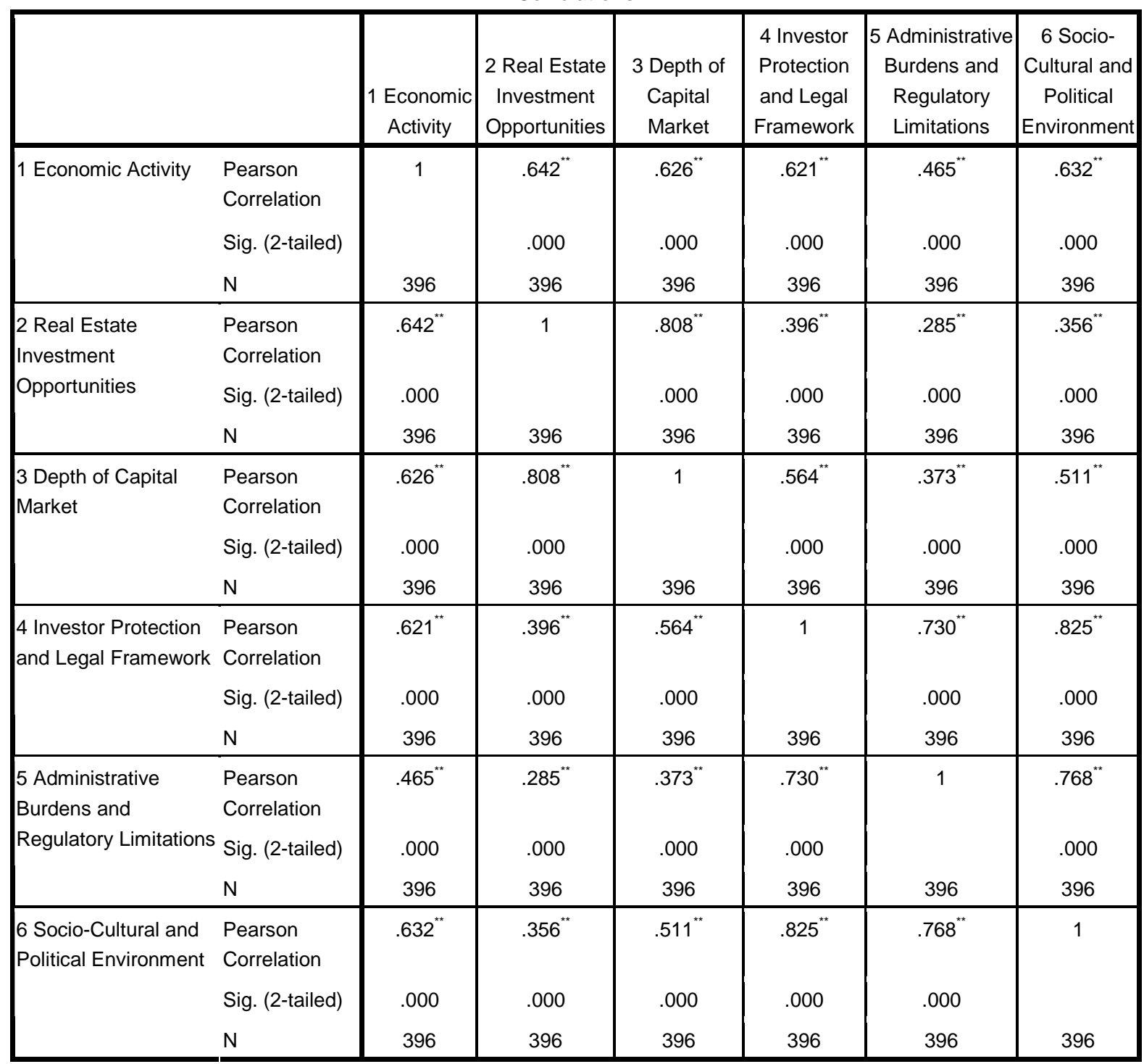

**. Correlation is significant at the 0.01 level (2-tailed).

Pooled correlation for the six key drivers (equal-weighted index) from 2004-2009. 


\section{Appendix C}

Factor Analysis

\section{Table A 1}

Factor Analysis - Economic Activity

KMO and Bartlett's Test

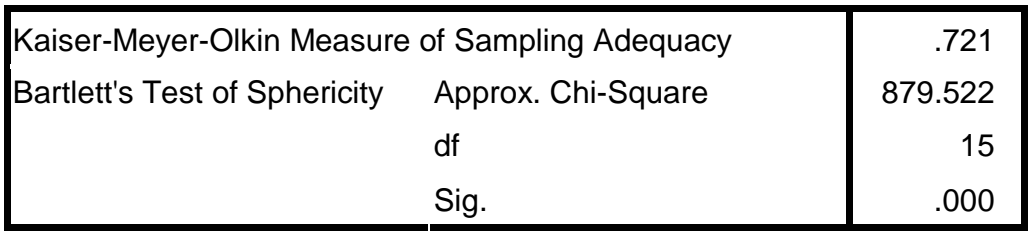

Anti-image Matrices

\begin{tabular}{|c|c|c|c|c|c|c|c|}
\hline & & $\begin{array}{l}\text { 1.1. Total } \\
\text { Economic } \\
\text { Size (LN } \\
\text { GDP) }\end{array}$ & $\begin{array}{l}\text { 1.2. GDP } \\
\text { per Capita }\end{array}$ & \begin{tabular}{|c|} 
1.3. Real \\
GDP Growth \\
(3 yrs Avg)
\end{tabular} & $\begin{array}{c}\text { 1.4. Working } \\
\text { Force }\end{array}$ & $\begin{array}{c}1.5 . \\
\text { Inflation }\end{array}$ & $\begin{array}{c}1.6 . \\
\text { Technological } \\
\text { Development } \\
\text { and Innovation }\end{array}$ \\
\hline \multirow[t]{6}{*}{$\begin{array}{l}\text { Anti-image } \\
\text { Covariance }\end{array}$} & $\begin{array}{l}\text { 1.1. Total Economic } \\
\text { Size (LN GDP) }\end{array}$ & .620 & .091 & .121 & -.107 & .061 & -.224 \\
\hline & 1.2. GDP per Capita & .091 & .387 & .177 & -.156 & -.054 & -.182 \\
\hline & $\begin{array}{l}\text { 1.3. Real GDP } \\
\text { Growth ( } 3 \text { yrs Avg) }\end{array}$ & .121 & .177 & .622 & -.204 & .131 & -.015 \\
\hline & 1.4. Working Force & -.107 & -.156 & -.204 & .777 & -.079 & .002 \\
\hline & 1.5. Inflation & .061 & -.054 & .131 & -.079 & .589 & -.138 \\
\hline & $\begin{array}{l}\text { 1.6. Technological } \\
\text { Development and } \\
\text { Innovation }\end{array}$ & -.224 & -.182 & -.015 & .002 & -.138 & .330 \\
\hline \multirow[t]{6}{*}{$\begin{array}{l}\text { Anti-image } \\
\text { Correlation }\end{array}$} & $\begin{array}{l}\text { 1.1. Total Economic } \\
\text { Size (LN GDP) }\end{array}$ & $.665^{\mathrm{a}}$ & .185 & .195 & -.154 & .101 & -.495 \\
\hline & 1.2. GDP per Capita & .185 & $.718^{\mathrm{a}}$ & .360 & -.285 & -.114 & -.510 \\
\hline & $\begin{array}{l}\text { 1.3. Real GDP } \\
\text { Growth ( } 3 \text { yrs Avg) }\end{array}$ & .195 & .360 & $.715^{\mathrm{a}}$ & -.293 & .216 & -.033 \\
\hline & 1.4. Working Force & -.154 & -.285 & -.293 & $.634^{\mathrm{a}}$ & -.117 & .005 \\
\hline & 1.5. Inflation & .101 & -.114 & .216 & -.117 & $.844^{\mathrm{a}}$ & -.313 \\
\hline & $\begin{array}{l}\text { 1.6. Technological } \\
\text { Development and } \\
\text { Innovation }\end{array}$ & -.495 & -.510 & -.033 & .005 & -.313 & $.709^{\mathrm{a}}$ \\
\hline
\end{tabular}

\footnotetext{
${ }^{\mathrm{a}}$ Measures of Sampling Adequacy (MSA).
} 
Item-Total Statistics

\begin{tabular}{|l|c|c|c|c|}
\hline & $\begin{array}{c}\text { Scale Mean if } \\
\text { Item Deleted }\end{array}$ & $\begin{array}{c}\text { Scale Variance if } \\
\text { Item Deleted }\end{array}$ & $\begin{array}{c}\text { Cronbach's } \\
\text { Corrected Item- } \\
\text { Total Correlation if Item } \\
\text { Deleted }\end{array}$ \\
\hline $\begin{array}{l}\text { 1.1. Total Economic Size (LN } \\
\text { GDP) }\end{array}$ & 298.5183 & 3198.274 & .410 & .435 \\
1.2. GDP per Capita & 284.0368 & 2544.779 & .540 & .335 \\
1.3. Real GDP Growth (3 yrs & 306.0056 & 5639.001 & -.496 & .792 \\
Avg) & 259.6087 & 3602.437 & .430 & .456 \\
1.4. Working Force & 265.3714 & 3099.040 & .479 & .402 \\
1.5. Inflation & 301.1363 & 2527.783 & .722 & .245 \\
1.6. Technological & & & & \\
Development and Innovation & & & & \\
\hline
\end{tabular}

KMO and Bartlett's Test

\begin{tabular}{|c|c|c|}
\hline \multicolumn{2}{|c|}{ Kaiser-Meyer-Olkin Measure of Sampling Adequacy } & .731 \\
\hline \multirow[t]{3}{*}{ Bartlett's Test of Sphericity } & Approx. Chi-Square & 693.757 \\
\hline & $\mathrm{df}$ & 10 \\
\hline & Sig. & .000 \\
\hline
\end{tabular}

Anti-image Matrices

\begin{tabular}{|c|c|c|c|c|c|c|}
\hline & & $\begin{array}{l}\text { 1.1. Total } \\
\text { Economic } \\
\text { Size (LN } \\
\text { GDP) }\end{array}$ & \begin{tabular}{|} 
1.2. GDP per \\
Capita
\end{tabular} & $\begin{array}{l}\text { 1.4. Working } \\
\text { Force }\end{array}$ & $\begin{array}{c}1.5 . \\
\text { Inflation }\end{array}$ & $\begin{array}{c}1.6 . \\
\text { Technological } \\
\text { Development } \\
\text { and Innovation }\end{array}$ \\
\hline \multirow[t]{5}{*}{$\begin{array}{l}\text { Anti-image } \\
\text { Covariance }\end{array}$} & $\begin{array}{l}\text { 1.1. Total Economic } \\
\text { Size (LN GDP) }\end{array}$ & .644 & .067 & -.077 & .039 & -.230 \\
\hline & 1.2. GDP per Capita & .067 & .445 & -.124 & -.110 & -.205 \\
\hline & 1.4. Working Force & -.077 & -.124 & .850 & -.042 & -.003 \\
\hline & 1.5. Inflation & .039 & -.110 & -.042 & .617 & -.142 \\
\hline & $\begin{array}{l}\text { 1.6. Technological } \\
\text { Development and } \\
\text { Innovation }\end{array}$ & -.230 & -.205 & -.003 & -.142 & .330 \\
\hline \multirow[t]{5}{*}{$\begin{array}{l}\text { Anti-image } \\
\text { Correlation }\end{array}$} & $\begin{array}{l}\text { 1.1. Total Economic } \\
\text { Size (LN GDP) }\end{array}$ & $.679^{a}$ & .126 & -.104 & .061 & -.498 \\
\hline & 1.2. GDP per Capita & .126 & $.732^{\mathrm{a}}$ & -.201 & -.210 & -.535 \\
\hline & 1.4. Working Force & -.104 & -.201 & $.867^{\mathrm{a}}$ & -.058 & -.005 \\
\hline & 1.5. Inflation & .061 & -.210 & -.058 & $.841^{\mathrm{a}}$ & -.313 \\
\hline & $\begin{array}{l}\text { 1.6. Technological } \\
\text { Development and } \\
\text { Innovation }\end{array}$ & -.498 & -.535 & -.005 & -.313 & $.670^{\mathrm{a}}$ \\
\hline
\end{tabular}

\footnotetext{
${ }^{a}$ Measures of Sampling Adequacy (MSA).
} 


\section{Communalities}

\begin{tabular}{|l|c|c|}
\hline & Initial & Extraction \\
\hline $\begin{array}{l}\text { 1.1. Total Economic Size (LN } \\
\text { GDP) }\end{array}$ & 1.000 & .424 \\
1.2. GDP per Capita & 1.000 & .692 \\
1.4. Working Force & 1.000 & .283 \\
1.5. Inflation & 1.000 & .553 \\
1.6. Technological & 1.000 & .802 \\
Development and Innovation & & \\
\hline
\end{tabular}

Extraction Method: Principal Component Analysis.

Total Variance Explained

\begin{tabular}{|c|c|c|c|c|c|c|}
\hline \multirow{2}{*}{ Component } & \multicolumn{4}{|c|}{ Initial Eigenvalues } & \multicolumn{3}{c|}{ Extraction Sums of Squared Loadings } \\
\cline { 2 - 7 } & Total & \% of Variance & Cumulative \% & Total & \% of Variance & Cumulative \% \\
\hline 1 & 2.754 & 55.074 & 55.074 & 2.754 & 55.074 & 55.074 \\
2 & .811 & 16.230 & 71.304 & & & \\
3 & .760 & 15.200 & 86.503 & & & \\
4 & .453 & 9.055 & 95.558 & & & \\
5 & .222 & 4.442 & 100.000 & & & \\
\hline
\end{tabular}

Extraction Method: Principal Component Analysis.

\section{Component Matrix ${ }^{\mathrm{a}}$}

\begin{tabular}{|l|c|}
\hline \multirow{2}{*}{} & Component \\
\cline { 2 - 2 } & 1 \\
\hline 1.1. Total Economic Size (LN GDP) & .651 \\
1.2. GDP per Capita & .832 \\
1.4. Working Force & .532 \\
1.5. Inflation & .744 \\
1.6. Technological Development and & .896 \\
Innovation & \\
\hline
\end{tabular}

Extraction Method: Principal Component Analysis.

a 1 component extracted. 


\section{Table A 2}

Calculation of the Weights from Factor Analysis - Economic Activity

1. Economic Activity

Component Matrix

\begin{tabular}{|c|c|c|c|}
\hline & $\begin{array}{c}\text { Component loadings } \\
1 \\
\end{array}$ & $\begin{array}{c}\text { Component weights } \\
1\end{array}$ & $\begin{array}{l}\text { Overall } \\
\text { Weights }\end{array}$ \\
\hline 1.1. Total Economic Size (LN GDP) & 0,651 & 0,154 & 0,154 \\
\hline 1.2. GDP per Capita & 0,832 & 0,251 & 0,251 \\
\hline 1.4. Working Force & 0,532 & 0,103 & 0,103 \\
\hline 1.5. Inflation & 0,744 & 0,201 & 0,201 \\
\hline 1.6. Technological Development and Innovation & 0,896 & 0,291 & 0,291 \\
\hline \multicolumn{4}{|l|}{ Extraction Method: Principal Component Analysis } \\
\hline $\begin{array}{l}\text { Expl. Var. } \\
\text { Expl. Tot. }\end{array}$ & $\begin{array}{l}2,755 \\
1,000\end{array}$ & $\begin{array}{l}1,000 \\
\text { Sum }\end{array}$ & $\begin{array}{l}1,000 \\
\text { Sum }\end{array}$ \\
\hline
\end{tabular}

\section{Table A 3}

Factor Analysis - Real Estate Investment Opportunities

\section{KMO and Bartlett's Test}

\begin{tabular}{|c|c|c|}
\hline \multicolumn{2}{|c|}{ Kaiser-Meyer-Olkin Measure of Sampling Adequacy } & .395 \\
\hline \multirow[t]{3}{*}{ Bartlett's Test of Sphericity } & Approx. Chi-Square & 613.709 \\
\hline & df & 10 \\
\hline & Sig. & .000 \\
\hline
\end{tabular}

Anti-image Matrices

\begin{tabular}{|c|c|c|c|c|c|c|}
\hline & & $\begin{array}{c}\text { 2.1. Size of } \\
\text { Real Estate } \\
\text { Market }\end{array}$ & $\begin{array}{l}\text { 2.2. Degree of } \\
\text { Urbanization }\end{array}$ & $\begin{array}{l}\text { 2.3. Urban } \\
\text { Population }\end{array}$ & $\begin{array}{l}\text { 2.4. Quality of } \\
\text { Infrastructure }\end{array}$ & $\begin{array}{c}\text { 2.5. Services } \\
\text { Total Output } \\
\text { per GDP }\end{array}$ \\
\hline \multirow[t]{5}{*}{$\begin{array}{l}\text { Anti-image } \\
\text { Covariance }\end{array}$} & $\begin{array}{l}\text { 2.1. Institutional Property } \\
\text { Estimation }\end{array}$ & .333 & -.287 & -.210 & -.234 & -.048 \\
\hline & 2.2. Degree of Urbanization & -.287 & .517 & .187 & .216 & .044 \\
\hline & 2.3. Urban Population & -.210 & .187 & .740 & .100 & .220 \\
\hline & 2.4. Quality of Infrastructure & -.234 & .216 & .100 & .421 & -.187 \\
\hline & $\begin{array}{l}\text { 2.5. Services Total Output } \\
\text { per GDP }\end{array}$ & -.048 & .044 & .220 & -.187 & .628 \\
\hline \multirow[t]{5}{*}{$\begin{array}{l}\text { Anti-image } \\
\text { Correlation }\end{array}$} & $\begin{array}{l}\text { 2.1. Institutional Property } \\
\text { Estimation }\end{array}$ & $.390^{a}$ & -.693 & -.422 & -.624 & -.105 \\
\hline & 2.2. Degree of Urbanization & -.693 & $.253^{\mathrm{a}}$ & .303 & .464 & .078 \\
\hline & 2.3. Urban Population & -.422 & .303 & $.254^{\mathrm{a}}$ & .179 & .322 \\
\hline & 2.4. Quality of Infrastructure & -.624 & .464 & .179 & $.438^{\mathrm{a}}$ & -.363 \\
\hline & $\begin{array}{l}\text { 2.5. Services Total Output } \\
\text { per GDP }\end{array}$ & -.105 & .078 & .322 & -.363 & $.646^{\mathrm{a}}$ \\
\hline
\end{tabular}

\footnotetext{
${ }^{a}$ Measures of Sampling Adequacy (MSA).
} 
Item-Total Statistics (1)

\begin{tabular}{|l|c|c|c|c|}
\hline & $\begin{array}{c}\text { Scale Mean if } \\
\text { Item Deleted }\end{array}$ & $\begin{array}{c}\text { Scale Variance if } \\
\text { Item Deleted }\end{array}$ & $\begin{array}{c}\text { Cronbach's } \\
\text { Corrected Item- } \\
\text { Total Correlation }\end{array}$ & $\begin{array}{c}\text { Alph Item } \\
\text { Deleted }\end{array}$ \\
\hline $\begin{array}{l}\text { 2.1. Institutional Property } \\
\text { Estimation }\end{array}$ & 152.5489 & 1479.828 & .739 & .118 \\
$\begin{array}{l}\text { 2.2. Degree of Urbanization } \\
\text { 2.3. Urban Population }\end{array}$ & 184.7700 & 2521.453 & .153 & .538 \\
$\begin{array}{l}\text { 2.4. Quality of Infrastructure } \\
\text { 2.5. Services Total Output } \\
\text { per GDP }\end{array}$ & 155.0838 & 2786.318 & -.049 & .643 \\
\hline
\end{tabular}

Item-Total Statistics (2)

\begin{tabular}{|c|c|c|c|c|}
\hline & $\begin{array}{l}\text { Scale Mean if } \\
\text { Item Deleted }\end{array}$ & $\begin{array}{c}\text { Scale Variance if } \\
\text { Item Deleted }\end{array}$ & $\begin{array}{l}\text { Corrected Item- } \\
\text { Total Correlation }\end{array}$ & $\begin{array}{c}\text { Cronbach's } \\
\text { Alpha if Item } \\
\text { Deleted }\end{array}$ \\
\hline $\begin{array}{l}\text { 2.1. Institutional Property } \\
\text { Estimation }\end{array}$ & 108.0062 & 1422.283 & .653 & .392 \\
\hline 2.2. Degree of Urbanization & 140.2273 & 2308.166 & .163 & .717 \\
\hline 2.4. Quality of Infrastructure & 111.4634 & 1472.690 & .517 & .501 \\
\hline $\begin{array}{l}\text { 2.5. Services Total Output } \\
\text { per GDP }\end{array}$ & 105.5544 & 1811.176 & .389 & .599 \\
\hline
\end{tabular}

KMO and Bartlett's Test

\begin{tabular}{|c|c|c|}
\hline \multicolumn{2}{|c|}{ Kaiser-Meyer-Olkin Measure of Sampling Adequacy } & .583 \\
\hline \multirow[t]{3}{*}{ Bartlett's Test of Sphericity } & Approx. Chi-Square & 274.947 \\
\hline & df & 3 \\
\hline & Sig. & .000 \\
\hline
\end{tabular}

Anti-image Matrices

\begin{tabular}{|ll|c|c|c|}
\hline & & $\begin{array}{c}\text { 2.1. Size of Real } \\
\text { Estate Market }\end{array}$ & $\begin{array}{c}\text { 2.4. Quality of } \\
\text { Infrastructure }\end{array}$ & $\begin{array}{c}\text { Total Output per } \\
\text { GDP }\end{array}$ \\
\hline Anti-image & 2.1. Institutional Property Estimation & .708 & -.299 & .020 \\
Covariance & 2.4. Quality of Infrastructure & -.299 & .538 & -.302 \\
& 2.5. Services Total Output per GDP & .020 & -.302 & .701 \\
\hline Anti-image & 2.1. Institutional Property Estimation & $.610^{\mathrm{a}}$ & -.484 & .028 \\
Correlation & 2.4. Quality of Infrastructure & -.484 & $.553^{\mathrm{a}}$ & -.491 \\
& 2.5. Services Total Output per GDP & .028 & -.491 & $.607^{\mathrm{a}}$ \\
\hline
\end{tabular}

\footnotetext{
${ }^{\mathrm{a}}$ Measures of Sampling Adequacy (MSA).
} 


\begin{tabular}{|c|c|c|}
\hline \multicolumn{3}{|c|}{ Communalities } \\
\hline & Initial & Extraction \\
\hline 2.1. Institutional Property Estimation & 1.000 & .560 \\
\hline 2.4. Quality of Infrastructure & 1.000 & .790 \\
\hline 2.5. Services Total Output per GDP & 1.000 & .567 \\
\hline
\end{tabular}

Extraction Method: Principal Component Analysis.

Total Variance Explained

\begin{tabular}{|c|c|c|c|c|c|c|}
\hline \multirow{2}{*}{$\begin{array}{c}\text { Compo- } \\
\text { nent }\end{array}$} & \multicolumn{3}{|c|}{ Initial Eigenvalues } & \multicolumn{3}{c|}{ Extraction Sums of Squared Loadings } \\
\cline { 2 - 7 } & Total & \% of Variance & Cumulative \% & Total & \% of Variance & Cumulative \% \\
\hline 1 & 1.917 & 63.914 & 63.914 & 1.917 & 63.914 & 63.914 \\
2 & .725 & 24.175 & 88.088 & & & \\
3 & .357 & 11.912 & 100.000 & & & \\
\hline
\end{tabular}

Extraction Method: Principal Component Analysis.

\section{Component Matrix ${ }^{\mathrm{a}}$}

\begin{tabular}{|l|c|}
\hline & Component \\
\cline { 2 - 2 } & 1 \\
\hline 2.1. Institutional Property Estimation & .749 \\
2.4. Quality of Infrastructure & .889 \\
2.5. Services Total Output per GDP & .753 \\
\hline
\end{tabular}

Extraction Method: Principal Component Analysis.

a 1 component extracted.

\section{Table A 4}

Calculation of the Weights from Factor Analysis -Real Estate Investment Opportunities

\section{Real Estate Investment Opportunities}

\begin{tabular}{l|c|c|c}
\hline Rotated Component Matrix & Component loadings & Component weights & Overall \\
& 1 & 1 & Weights \\
\hline 2.1. Institutional Property Estimation & 0.749 & 0.292 & 0.292 \\
2.4. Quality of Infrastructure & 0.889 & 0.412 & 0.412 \\
2.5. Services Total Output per GDP & 0.753 & 0.296 & 0.296 \\
\hline Extraction Method: Principal Component Analysis & & & \\
\hline Expl. Var. & 1.918 & 1.000 & 1.000 \\
Expl. /Tot. & 1.000 & Sum & Sum \\
\hline
\end{tabular}




\section{Table A 5}

Factor Analysis - Depth of Capital Market

KMO and Bartlett's Test

\begin{tabular}{|ll|r|}
\hline Kaiser-Meyer-Olkin Measure of Sampling Adequacy & .875 \\
Bartlett's Test of Sphericity & Approx. Chi-Square & 1500.240 \\
& df & 15 \\
Sig. & .000 \\
\hline
\end{tabular}

Anti-image Matrices

\begin{tabular}{|c|c|c|c|c|c|c|c|}
\hline & & $\begin{array}{c}\text { 3.1. Size and } \\
\text { Liquidity of } \\
\text { the Stock } \\
\text { Market }\end{array}$ & $\begin{array}{l}\text { 3.2. IPO } \\
\text { Market } \\
\text { Activity }\end{array}$ & $\begin{array}{c}\text { 3.3. M\&A } \\
\text { Market } \\
\text { Activity }\end{array}$ & $\begin{array}{c}\text { 3.4. Access } \\
\text { to Debt \& } \\
\text { Credit } \\
\text { Market }\end{array}$ & $\begin{array}{l}\text { 3.5. Access } \\
\text { to Private } \\
\text { Capital }\end{array}$ & \begin{tabular}{|c|} 
3.6. REIT \\
Market \\
Capitalization
\end{tabular} \\
\hline \multirow[t]{6}{*}{$\begin{array}{l}\text { Anti-image } \\
\text { Covariance }\end{array}$} & $\begin{array}{l}\text { 3.1. Size and } \\
\text { Liquidity of the } \\
\text { Stock Market }\end{array}$ & .364 & -.108 & -.022 & -.176 & -.088 & -.027 \\
\hline & $\begin{array}{l}\text { 3.2. IPO Market } \\
\text { Activity }\end{array}$ & -.108 & .321 & -.141 & .083 & -.071 & -.029 \\
\hline & $\begin{array}{l}\text { 3.3. M\&A Market } \\
\text { Activity }\end{array}$ & -.022 & -.141 & .287 & -.047 & -.047 & -.126 \\
\hline & $\begin{array}{l}\text { 3.4. Access to Debt } \\
\text { and Credit Market }\end{array}$ & -.176 & .083 & -.047 & .585 & -.050 & -.074 \\
\hline & $\begin{array}{l}\text { 3.5. Access to } \\
\text { Private Capital }\end{array}$ & -.088 & -.071 & -.047 & -.050 & .438 & -.072 \\
\hline & $\begin{array}{l}\text { 3.6. REIT Market } \\
\text { Capitalization }\end{array}$ & -.027 & -.029 & -.126 & -.074 & -.072 & .413 \\
\hline \multirow[t]{6}{*}{$\begin{array}{l}\text { Anti-image } \\
\text { Correlation }\end{array}$} & $\begin{array}{l}\text { 3.1. Size and } \\
\text { Liquidity of the } \\
\text { Stock Market }\end{array}$ & $.873^{\mathrm{a}}$ & -.316 & -.068 & -.381 & -.220 & -.071 \\
\hline & $\begin{array}{l}\text { 3.2. IPO Market } \\
\text { Activity }\end{array}$ & -.316 & $.840^{\mathrm{a}}$ & -.463 & .192 & -.188 & -.079 \\
\hline & $\begin{array}{l}\text { 3.3. M\&A Market } \\
\text { Activity }\end{array}$ & -.068 & -.463 & $.855^{\mathrm{a}}$ & -.115 & -.133 & -.365 \\
\hline & $\begin{array}{l}\text { 3.4. Access to Debt } \\
\text { and Credit Market }\end{array}$ & -.381 & 192 & -.115 & $.844^{\mathrm{a}}$ & -.099 & -.151 \\
\hline & $\begin{array}{l}\text { 3.5. Access to } \\
\text { Private Capital }\end{array}$ & -.220 & -188 & -.133 & -099 & $.933^{\mathrm{a}}$ & -.168 \\
\hline & $\begin{array}{l}\text { 3.6. REIT Market } \\
\text { Capitalization }\end{array}$ & -.071 & -.079 & -.365 & -.151 & -.168 & $.909^{\mathrm{a}}$ \\
\hline
\end{tabular}

${ }^{a}$ Measures of Sampling Adequacy (MSA). 
Total Variance Explained

\begin{tabular}{|c|c|c|c|c|c|c|}
\hline \multirow{2}{*}{ Component } & \multicolumn{3}{|c|}{ Initial Eigenvalues } & \multicolumn{3}{c|}{ Extraction Sums of Squared Loadings } \\
\cline { 2 - 7 } & Total & \% of Variance & Cumulative \% & Total & \% of Variance & Cumulative \% \\
\hline 1 & 4.081 & 68.015 & 68.015 & 4.081 & 68.015 & 68.015 \\
2 & .677 & 11.289 & 79.304 & & & \\
3 & .413 & 6.885 & 86.188 & & & \\
4 & .362 & 6.037 & 92.226 & & & \\
5 & .274 & 4.569 & 96.794 & & & \\
6 & .192 & 3.206 & 100.000 & & & \\
\hline
\end{tabular}

Extraction Method: Principal Component Analysis.

\section{Component Matrix ${ }^{\mathrm{a}}$}

\begin{tabular}{|l|c|}
\hline & Component \\
\cline { 2 - 2 } & 1 \\
\hline 3.1. Size and Liquidity of the Stock & .856 \\
Market & \\
3.2. IPO Market Activity & .849 \\
3.3. M\&A Market Activity & .884 \\
3.4. Access to Debt and Credit Market & .681 \\
3.5. Access to Private Capital & .830 \\
3.6. REIT Market Capitalization & .833 \\
\hline
\end{tabular}

Extraction Method: Principal Component Analysis.

a 1 component extracted.

Table A 6

Calculation of the Weights from Factor Analysis - Depth of Capital Market

3. Depth of Capital Market

\begin{tabular}{l|c|c|c}
\hline Component Matrix & \multicolumn{3}{c}{} \\
\hline & $\begin{array}{c}\text { Component loadings } \\
\text { Component weights }\end{array}$ & $\begin{array}{c}\text { Overall } \\
\text { Weights }\end{array}$ \\
\hline 3.1. Size and Liquidity of the Stock Market & 1 & 0,180 & 0,180 \\
3.2. IPO Market Activity & 0,856 & 0,177 & 0,177 \\
3.3. M\&A Market Activity & 0,884 & 0,191 & 0,191 \\
3.4. Access to Debt and Credit Market & 0,681 & 0,114 & 0,114 \\
3.5. Access to Private Capital & 0,830 & 0,169 & 0,169 \\
3.6. REIT Market Capitalization & 0,833 & 0,170 & 0,170 \\
\hline Extraction Method: Principal Component Analysis & & & \\
\hline Expl. Var. & 4,082 & 1,000 & 1,000 \\
Expl. /Tot. & 1,000 & Sum & Sum \\
\hline
\end{tabular}




\section{Table A 7}

Factor Analysis - Investor Protection and Legal Framework

KMO and Bartlett's Test

\begin{tabular}{|ll|r|}
\hline Kaiser-Meyer-Olkin Measure of Sampling Adequacy & .733 \\
Bartlett's Test of Sphericity & Approx. Chi-Square & 1042.434 \\
& df & 6 \\
Sig. & .000 \\
\hline
\end{tabular}

\section{Anti-image Matrices}

\begin{tabular}{|c|c|c|c|c|c|}
\hline & & $\begin{array}{l}\text { 4.1. Investor } \\
\text { Protection }\end{array}$ & $\begin{array}{c}\text { 4.2. Security } \\
\text { of Property } \\
\text { Rights }\end{array}$ & $\begin{array}{l}\text { 4.3. Quality of } \\
\text { Legal } \\
\text { Enforcement }\end{array}$ & $\begin{array}{c}4.4 . \\
\text { Regulatory } \\
\text { Quality }\end{array}$ \\
\hline \multirow{4}{*}{$\begin{array}{l}\text { Anti-image } \\
\text { Covariance }\end{array}$} & 4.1. Investor Protection & .702 & -.189 & .042 & -.040 \\
\hline & 4.2. Security of Property Rights & -.189 & .377 & -.034 & -.093 \\
\hline & 4.3. Quality of Legal Enforcement & .042 & -.034 & .226 & -.155 \\
\hline & 4.4. Regulatory Quality & -.040 & -.093 & -.155 & .186 \\
\hline \multirow{4}{*}{$\begin{array}{l}\text { Anti-image } \\
\text { Correlation }\end{array}$} & 4.1. Investor Protection & $.789^{\mathrm{a}}$ & -.368 & .105 & -.112 \\
\hline & 4.2. Security of Property Rights & -.368 & $.829^{\mathrm{a}}$ & -.118 & -.350 \\
\hline & 4.3. Quality of Legal Enforcement & .105 & -.118 & $.694^{\mathrm{a}}$ & -.759 \\
\hline & 4.4. Regulatory Quality & -.112 & -.350 & -.759 & $.681^{\mathrm{a}}$ \\
\hline
\end{tabular}

\footnotetext{
${ }^{\mathrm{a}}$ Measures of Sampling Adequacy (MSA).
}

Total Variance Explained

\begin{tabular}{|c|c|c|c|c|c|c|}
\hline \multirow{2}{*}{$\begin{array}{c}\text { Compo- } \\
\text { nent }\end{array}$} & \multicolumn{3}{|c|}{ Initial Eigenvalues } & \multicolumn{3}{c|}{ Extraction Sums of Squared Loadings } \\
\cline { 2 - 7 } & Total & \% of Variance & Cumulative \% & Total & \% of Variance & Cumulative \% \\
\hline 1 & 2.853 & 71.313 & 71.313 & 2.853 & 71.313 & 71.313 \\
2 & .743 & 18.569 & 89.882 & & & \\
3 & .290 & 7.257 & 97.138 & & & \\
4 & .114 & 2.862 & 100.000 & & & \\
\hline
\end{tabular}

Extraction Method: Principal Component Analysis.

\section{Component Matrix ${ }^{\mathrm{a}}$}

\begin{tabular}{|l|c|}
\hline & Component \\
\cline { 2 - 2 } & 1 \\
\hline 4.1. Investor Protection & .640 \\
4.2. Security of Property Rights & .889 \\
4.3. Quality of Legal Enforcement & .889 \\
4.4. Regulatory Quality & .929 \\
\hline
\end{tabular}

Extraction Method: Principal Component Analysis.

a 1 component extracted. 


\section{Table A 8}

Calculation of the Weights from Factor Analysis - Investor Protection and Legal Framework

4. Investor Protection and Legal Framework

\begin{tabular}{|c|c|c|c|}
\hline \multicolumn{4}{|l|}{ Component Matrix } \\
\hline & $\begin{array}{c}\text { Component loadings } \\
1\end{array}$ & $\begin{array}{c}\text { Component weights } \\
1\end{array}$ & $\begin{array}{c}\text { Overall } \\
\text { Weights }\end{array}$ \\
\hline 4.1. Investor Protection & 0,640 & 0,144 & 0,144 \\
\hline 4.2. Security of Property Rights & 0,889 & 0,277 & 0,277 \\
\hline 4.3. Quality of Legal Enforcement & 0,889 & 0,277 & 0,277 \\
\hline 4.4. Regulatory Quality & 0,929 & 0,302 & 0,302 \\
\hline \multicolumn{4}{|c|}{ Extraction Method: Principal Component Analysis } \\
\hline Expl. Var. & 2,853 & 1,000 & 1,000 \\
\hline Expl. /Tot. & 1,000 & Sum & Sum \\
\hline
\end{tabular}

\section{Table A 9}

Factor Analysis - Administrative Burdens and Regulatory Limitations

KMO and Bartlett's Test

\begin{tabular}{|c|c|c|}
\hline \multicolumn{2}{|c|}{ Kaiser-Meyer-Olkin Measure of Sampling Adequacy } & .723 \\
\hline \multirow[t]{3}{*}{ Bartlett's Test of Sphericity } & Approx. Chi-Square & 615.027 \\
\hline & df & 15 \\
\hline & Sig. & .000 \\
\hline
\end{tabular}

\begin{tabular}{|c|c|c|c|c|c|c|c|}
\hline \multicolumn{8}{|c|}{ Anti-image Matrices } \\
\hline & & $\begin{array}{c}5.1 . \\
\text { Taxation }\end{array}$ & $\begin{array}{c}\text { 5.2. Ease of } \\
\text { Getting a } \\
\text { Construction } \\
\text { Permit }\end{array}$ & $\begin{array}{l}\text { 5.3. Ease of } \\
\text { Registering } \\
\text { Property }\end{array}$ & \begin{tabular}{|c|} 
5.4. Ease of \\
Starting a \\
Business
\end{tabular} & $\begin{array}{c}\text { 5.5. Ease of } \\
\text { Closing a } \\
\text { Business }\end{array}$ & $\begin{array}{l}\text { 5.6. Foreign } \\
\text { Exchange } \\
\text { Controls }\end{array}$ \\
\hline \multirow{6}{*}{$\begin{array}{l}\text { Anti-image } \\
\text { Covariance }\end{array}$} & 5.1. Taxation & .917 & .170 & -.075 & .007 & .105 & -.133 \\
\hline & $\begin{array}{l}\text { 5.2. Ease of Getting a } \\
\text { Construction Permit }\end{array}$ & .170 & .677 & -.192 & .028 & -.054 & -.184 \\
\hline & $\begin{array}{l}\text { 5.3. Ease of Registering } \\
\text { Property }\end{array}$ & -.075 & -.192 & .850 & -.147 & -.005 & .042 \\
\hline & 5.4. Ease of Starting a Business & .007 & .028 & -.147 & .572 & -.166 & -.160 \\
\hline & 5.5. Ease of Closing a Business & .105 & -.054 & -.005 & -.166 & .505 & -.201 \\
\hline & 5.6. Foreign Exchange Controls & -.133 & -.184 & .042 & -.160 & -.201 & .456 \\
\hline \multirow{6}{*}{$\begin{array}{l}\text { Anti-image } \\
\text { Correlation }\end{array}$} & 5.1. Taxation & $.274^{\mathrm{a}}$ & .215 & -.085 & .010 & .154 & -.205 \\
\hline & $\begin{array}{l}\text { 5.2. Ease of Getting a } \\
\text { Construction Permit }\end{array}$ & .215 & $.729^{\mathrm{a}}$ & -.253 & .045 & -.093 & -.330 \\
\hline & $\begin{array}{l}\text { 5.3. Ease of Registering } \\
\text { Property }\end{array}$ & -.085 & -.253 & $.691^{\mathrm{a}}$ & -.211 & -.007 & .067 \\
\hline & 5.4. Ease of Starting a Business & .010 & .045 & -.211 & $.780^{\mathrm{a}}$ & -.308 & -.313 \\
\hline & 5.5. Ease of Closing a Business & .154 & -.093 & -.007 & -.308 & $.760^{\mathrm{a}}$ & -.418 \\
\hline & 5.6. Foreign Exchange Controls & -.205 & -.330 & .067 & -.313 & -.418 & $.703^{\mathrm{a}}$ \\
\hline
\end{tabular}

\footnotetext{
${ }^{\mathrm{a}}$ Measures of Sampling Adequacy (MSA).
} 
KMO and Bartlett's Test

\begin{tabular}{|c|c|c|}
\hline \multicolumn{2}{|c|}{ Kaiser-Meyer-Olkin Measure of Sampling Adequacy } & .762 \\
\hline \multirow[t]{3}{*}{ Bartlett's Test of Sphericity } & Approx. Chi-Square & 581.724 \\
\hline & df & 10 \\
\hline & Sig. & .000 \\
\hline
\end{tabular}

\section{Anti-image Matrices}

\begin{tabular}{|c|c|c|c|c|c|c|}
\hline & & $\begin{array}{c}\text { 5.2. Ease of } \\
\text { Getting a } \\
\text { Construction } \\
\text { Permit }\end{array}$ & $\begin{array}{c}\text { 5.3. Ease of } \\
\text { Registering } \\
\text { Property }\end{array}$ & $\begin{array}{c}\text { 5.4. Ease of } \\
\text { Starting a } \\
\text { Business }\end{array}$ & $\begin{array}{c}\text { 5.5. Ease of } \\
\text { Closing a } \\
\text { Business }\end{array}$ & $\begin{array}{c}\text { 5.6. Foreign } \\
\text { Exchange } \\
\text { Controls }\end{array}$ \\
\hline \multirow[t]{5}{*}{$\begin{array}{l}\text { Anti-image } \\
\text { Covariance }\end{array}$} & $\begin{array}{l}\text { 5.2. Ease of Getting a } \\
\text { Construction Permit }\end{array}$ & .710 & -.188 & .028 & -.079 & -.174 \\
\hline & $\begin{array}{l}\text { 5.3. Ease of } \\
\text { Registering Property }\end{array}$ & -.188 & .856 & -.147 & .004 & .032 \\
\hline & $\begin{array}{l}\text { 5.4. Ease of Starting } \\
\text { a Business }\end{array}$ & .028 & -.147 & .572 & -.171 & -.166 \\
\hline & $\begin{array}{l}\text { 5.5. Ease of Closing a } \\
\text { Business }\end{array}$ & -.079 & .004 & -.171 & .518 & -.199 \\
\hline & $\begin{array}{l}\text { 5.6. Foreign } \\
\text { Exchange Controls }\end{array}$ & -.174 & .032 & -.166 & -.199 & .476 \\
\hline \multirow[t]{5}{*}{$\begin{array}{l}\text { Anti-image } \\
\text { Correlation }\end{array}$} & $\begin{array}{l}\text { 5.2. Ease of Getting a } \\
\text { Construction Permit }\end{array}$ & $.780^{\mathrm{a}}$ & -.241 & .043 & -.131 & -.299 \\
\hline & $\begin{array}{l}\text { 5.3. Ease of } \\
\text { Registering Property }\end{array}$ & -.241 & $.718^{\mathrm{a}}$ & -.211 & .006 & .050 \\
\hline & $\begin{array}{l}\text { 5.4. Ease of Starting } \\
\text { a Business }\end{array}$ & .043 & -.211 & $.775^{\mathrm{a}}$ & -.314 & -.318 \\
\hline & $\begin{array}{l}\text { 5.5. Ease of Closing a } \\
\text { Business }\end{array}$ & -.131 & .006 & -.314 & $.774^{\mathrm{a}}$ & -.400 \\
\hline & $\begin{array}{l}\text { 5.6. Foreign } \\
\text { Exchange Controls }\end{array}$ & -.299 & .050 & -.318 & -.400 & $.742^{\mathrm{a}}$ \\
\hline
\end{tabular}

\footnotetext{
${ }^{a}$ Measures of Sampling Adequacy (MSA).
}

\section{Communalities}

\begin{tabular}{|l|c|c|}
\hline & Initial & Extraction \\
\hline 5.2. Ease of Getting a Construction Permit & 1.000 & .459 \\
5.3. Ease of Registering Property & 1.000 & .220 \\
5.4. Ease of Starting a Business & 1.000 & .614 \\
5.5. Ease of Closing a Business & 1.000 & .665 \\
5.6. Foreign Exchange Controls & 1.000 & .704 \\
\hline
\end{tabular}

Extraction Method: Principal Component Analysis. 
Total Variance Explained

\begin{tabular}{|c|c|c|c|c|c|c|}
\hline \multirow{2}{*}{ Component } & \multicolumn{5}{|c|}{ Initial Eigenvalues } & \multicolumn{3}{c|}{ Extraction Sums of Squared Loadings } \\
\cline { 2 - 7 } & Total & \% of Variance & Cumulative \% & Total & \% of Variance & Cumulative \% \\
\hline 1 & 2.663 & 53.259 & 53.259 & 2.663 & 53.259 & 53.259 \\
2 & .909 & 18.173 & 71.431 & & & \\
3 & .687 & 13.744 & 85.175 & & & \\
4 & .398 & 7.957 & 93.132 & & & \\
5 & .343 & 6.868 & 100.000 & & & \\
\hline
\end{tabular}

Extraction Method: Principal Component Analysis.

\section{Component Matrix ${ }^{\mathrm{a}}$}

\begin{tabular}{|l|c|}
\hline & Component \\
\cline { 2 - 2 } & 1 \\
\hline 5.2. Ease of Getting a Construction Permit & .677 \\
5.3. Ease of Registering Property & .469 \\
5.4. Ease of Starting a Business & .784 \\
5.5. Ease of Closing a Business & .816 \\
5.6. Foreign Exchange Controls & .839 \\
\hline
\end{tabular}

Extraction Method: Principal Component Analysis.

a 1 component extracted.

\section{Table A 101}

Calculation of the Weights from Factor Analysis - Administrative Burdens and Regulatory Limitations

\section{Administrative Burdens \& Regulatory Limitations}

\begin{tabular}{l|c|c|c}
\hline Rotated Component Matrix & \multicolumn{3}{c}{} \\
\hline & Component loadings & Component weights & $\begin{array}{c}\text { Overall } \\
\text { Weights }\end{array}$ \\
\hline 5.2. Ease of Getting a Construction Permit & 1 & 0,172 & 0,172 \\
5.3. Ease of Registering Property & 0,677 & 0,083 & 0,083 \\
5.4. Ease of Starting a Business & 0,469 & 0,231 & 0,231 \\
5.5. Ease of Closing a Business & 0,784 & 0,250 & 0,250 \\
5.6. Foreign Exchange Controls & 0,816 & 0,264 & 0,264 \\
\hline Extraction Method: Principal Component Analysis & 0,839 & & \\
\hline Expl. Var. & 2,663 & 1,000 & 1,000 \\
Expl. /Tot. & 1,000 & Sum & Sum \\
\hline
\end{tabular}




\section{Table A 11}

Factor Analysis - Socio-Cultural and Political Environment

KMO and Bartlett's Test

\begin{tabular}{|ll|r|}
\hline Kaiser-Meyer-Olkin Measure of Sampling Adequacy & .809 \\
Bartlett's Test of Sphericity & Approx. Chi-Square & 1227.415 \\
& df & 6 \\
Sig. & .000 \\
\hline
\end{tabular}

Anti-image Matrices

\begin{tabular}{|ll|c|c|c|c|}
\hline & & $\begin{array}{c}\text { 6.1. Human } \\
\text { Development }\end{array}$ & 6.2. Crime & $\begin{array}{c}\text { 6.3. Bribery } \\
\text { and Corruption }\end{array}$ & $\begin{array}{c}\text { 6.4. Quality of } \\
\text { Political } \\
\text { System }\end{array}$ \\
\hline Anti-image & 6.1. Human Development & .369 & -.004 & -.055 & -.100 \\
Covariance & 6.2. Crime & -.004 & .528 & -.113 & -.015 \\
& 6.3. Bribery and Corruption & -.055 & -.113 & .186 & -.122 \\
& 6.4. Quality of Political System & -.100 & -.015 & -.122 & .193 \\
\hline Anti-image & 6.1. Human Development & $.888^{\mathrm{a}}$ & -.010 & -.209 & -.374 \\
Correlation & 6.2. Crime & -.010 & $.896^{\mathrm{a}}$ & -.361 & -.047 \\
& 6.3. Bribery and Corruption & -.209 & -.361 & $.755^{\mathrm{a}}$ & -.643 \\
& 6.4. Quality of Political System & -.374 & -.047 & -.643 & $.761^{\mathrm{a}}$ \\
\hline
\end{tabular}

${ }^{\mathrm{a}}$ Measures of Sampling Adequacy (MSA).

Total Variance Explained

\begin{tabular}{|c|c|c|c|c|c|c|}
\hline \multirow{2}{*}{$\begin{array}{c}\text { Compo- } \\
\text { nent }\end{array}$} & \multicolumn{3}{|c|}{ Initial Eigenvalues } & \multicolumn{3}{c|}{ Extraction Sums of Squared Loadings } \\
\cline { 2 - 7 } & Total & \% of Variance & Cumulative \% & Total & $\%$ of Variance & Cumulative \% \\
\hline 1 & 3.142 & 78.545 & 78.545 & 3.142 & 78.545 & 78.545 \\
2 & .497 & 12.436 & 90.981 & & & \\
3 & .247 & 6.170 & 97.151 & & & \\
4 & .114 & 2.849 & 100.000 & & & \\
\hline
\end{tabular}

Extraction Method: Principal Component Analysis.

\section{Component Matrix ${ }^{\mathrm{a}}$}

\begin{tabular}{|l|c|}
\hline \multirow{2}{*}{} & Component \\
\cline { 2 - 2 } & 1 \\
\hline 6.1. Human Development & .870 \\
6.2. Crime & .789 \\
6.3. Bribery and Corruption & .943 \\
6.4. Quality of Political System & .934 \\
\hline
\end{tabular}

Extraction Method: Principal Component Analysis.

a 1 component extracted. 


\section{Table A 12}

Calculation of the Weights from Factor Analysis - Socio-Cultural and Political Environment

\section{Socio-Cultural and Political Environment}

\begin{tabular}{l|c|c|c}
\hline Component Matrix & \multicolumn{3}{c}{} \\
\hline & Component loadings & $\begin{array}{c}\text { Component weights } \\
\text { Overall } \\
\text { Weights }\end{array}$ \\
\hline 6.1. Human Development & 1 & 0,241 & 0,241 \\
6.2. Crime & 0,870 & 0,198 & 0,198 \\
6.3. Bribing and Corruption & 0,943 & 0,283 & 0,283 \\
6.4. Quality of Political System & 0,934 & 0,278 & 0,278 \\
\hline Extraction Method: Principal Component Analysis & & & \\
\hline Expl. Var. & 3,141 & 1,000 & 1,000 \\
Expl. /Tot. & 1,000 & Sum & Sum \\
\hline
\end{tabular}

\section{Table A 13}

Factor Analysis - Real Estate Investment Index

KMO and Bartlett's Test

\begin{tabular}{|c|c|c|}
\hline \multicolumn{2}{|c|}{ Kaiser-Meyer-Olkin Measure of Sampling Adequacy } & .852 \\
\hline \multirow[t]{3}{*}{ Bartlett's Test of Sphericity } & Approx. Chi-Square & 2413.531 \\
\hline & & 15 \\
\hline & Sig. & .000 \\
\hline
\end{tabular}

\begin{tabular}{|c|c|c|c|c|c|c|c|}
\hline \multicolumn{8}{|c|}{ Anti-image Matrices } \\
\hline & & $\begin{array}{l}\text { 1. Economic } \\
\text { Activity }\end{array}$ & $\begin{array}{l}\text { 2. Depth and } \\
\text { Development } \\
\text { of RE Market }\end{array}$ & $\begin{array}{c}\text { 3. Depth } \\
\text { of Capital } \\
\text { Market }\end{array}$ & \begin{tabular}{|c|} 
4. Investor \\
Protection \\
and Legal \\
Framework
\end{tabular} & $\begin{array}{l}\text { 5. Administrative } \\
\text { Burdens and } \\
\text { Regulatory } \\
\text { Limitations }\end{array}$ & $\begin{array}{l}\text { 6. Socio- } \\
\text { Cultural and } \\
\text { Political } \\
\text { Environment }\end{array}$ \\
\hline \multirow{6}{*}{$\begin{array}{l}\text { Anti-image } \\
\text { Covariance }\end{array}$} & 1. Economic Activity & .171 & -.073 & -.078 & -.019 & .017 & -.064 \\
\hline & $\begin{array}{l}\text { 2. Depth and Development } \\
\text { of RE Market }\end{array}$ & -.073 & .206 & -.120 & .030 & -.056 & -.025 \\
\hline & 3. Depth of Capital Market & -.078 & -.120 & .313 & -.052 & .037 & .066 \\
\hline & $\begin{array}{l}\text { 4. Investor Protection and } \\
\text { Legal Framework }\end{array}$ & -.019 & .030 & -.052 & .195 & -.093 & -.088 \\
\hline & $\begin{array}{l}\text { 5. Administrative Burdens } \\
\text { and Regulatory Limitations }\end{array}$ & .017 & -.056 & .037 & -.093 & .282 & -.057 \\
\hline & $\begin{array}{l}\text { 6. Socio-Cultural and } \\
\text { Political Environment }\end{array}$ & -.064 & -.025 & .066 & -.088 & -.057 & .167 \\
\hline \multirow{6}{*}{$\begin{array}{l}\text { Anti-image } \\
\text { Correlation }\end{array}$} & 1. Economic Activity & $.874^{\mathrm{a}}$ & -.389 & -.336 & -.106 & .079 & -.380 \\
\hline & $\begin{array}{l}\text { 2. Depth and Development } \\
\text { of RE Market }\end{array}$ & -.389 & $.853^{\mathrm{a}}$ & -.474 & .149 & -.231 & -.133 \\
\hline & 3. Depth of Capital Market & -.336 & -.474 & $.803^{\mathrm{a}}$ & -.211 & .124 & .288 \\
\hline & $\begin{array}{l}\text { 4. Investor Protection and } \\
\text { Legal Framework }\end{array}$ & -.106 & .149 & -.211 & $.853^{\mathrm{a}}$ & -.397 & -.489 \\
\hline & $\begin{array}{l}\text { 5. Administrative Burdens } \\
\text { and Regulatory Limitations }\end{array}$ & .079 & -.231 & .124 & -.397 & $.889^{a}$ & -.263 \\
\hline & $\begin{array}{l}\text { 6. Socio-Cultural and } \\
\text { Political Environment }\end{array}$ & -.380 & -.133 & .288 & -.489 & -.263 & $.835^{\mathrm{a}}$ \\
\hline
\end{tabular}

\footnotetext{
${ }^{\mathrm{a}}$ Measures of Sampling Adequacy (MSA).
} 


\section{Communalities}

\begin{tabular}{|l|c|c|}
\hline & Initial & Extraction \\
\hline 1. Economic Activity & 1.000 & .857 \\
2. Depth and Development of & 1.000 & .796 \\
RE Market & 1.000 & .589 \\
3. Depth of Capital Market & 1.000 & .802 \\
4. Investor Protection and Legal \\
Framework & 1.000 & .713 \\
$\begin{array}{l}\text { 5. Administrative Burdens and } \\
\text { Regulatory Limitations }\end{array}$ & 1.000 & .814 \\
$\begin{array}{l}\text { 6. Socio-Cultural and Political } \\
\text { Environment }\end{array}$ & & \\
\hline
\end{tabular}

Extraction Method: Principal Component Analysis.

Total Variance Explained

\begin{tabular}{|c|c|c|c|c|c|c|}
\hline \multirow{2}{*}{ Component } & \multicolumn{3}{|c|}{ Initial Eigenvalues } & \multicolumn{3}{c|}{ Extraction Sums of Squared Loadings } \\
\cline { 2 - 7 } & Total & \% of Variance & Cumulative \% & Total & \% of Variance & Cumulative \% \\
\hline 1 & 4.571 & 76.191 & 76.191 & 4.571 & 76.191 & 76.191 \\
2 & .760 & 12.673 & 88.863 & & & \\
3 & .231 & 3.848 & 92.711 & & & \\
4 & .215 & 3.577 & 96.288 & & & \\
5 & .120 & 1.993 & 98.281 & & & \\
6 & .103 & 1.719 & 100.000 & & & \\
\hline
\end{tabular}

Extraction Method: Principal Component Analysis. 


\section{Component Matrix ${ }^{\mathrm{a}}$}

\begin{tabular}{|l|c|}
\hline & Component \\
\cline { 2 - 2 } & 1 \\
\hline 1. Economic Activity & .926 \\
2. Depth and Development of \\
RE Market & .892 \\
3. Depth of Capital Market \\
4. Investor Protection and Legal \\
$\begin{array}{l}\text { Framework } \\
\text { 5. Administrative Burdens and } \\
\text { Regulatory Limitations } \\
\text { 6. Socio-Cultural and Political } \\
\text { Environment }\end{array}$ \\
\hline
\end{tabular}

Extraction Method: Principal Component Analysis.

a 1 component extracted.

\section{Table A 14}

Calculation of the Weights from Factor Analysis - Real Estate Index

Real Estate Investment Index

\begin{tabular}{|c|c|c|c|}
\hline \multicolumn{4}{|l|}{ Rotated Component Matrix } \\
\hline & $\begin{array}{c}\text { Component loadings } \\
1 \\
\end{array}$ & $\begin{array}{c}\text { Component weights } \\
1 \\
\end{array}$ & $\begin{array}{r}\text { Overall } \\
\text { Weights }\end{array}$ \\
\hline 1. Economic Activity & 0,926 & 0,187 & 0,187 \\
\hline 2. Depth and Development of RE Market & 0,892 & 0,174 & 0,174 \\
\hline 3. Depth of Capital Market & 0,768 & 0,129 & 0,129 \\
\hline 4. Investor Protection and Legal Framework & 0,896 & 0,176 & 0,176 \\
\hline 5. Administrative Burdens and Regulatory Limitations & 0,845 & 0,156 & 0,156 \\
\hline 6. Socio-cultural and Political Environment & 0,902 & 0,178 & 0,178 \\
\hline \multicolumn{4}{|l|}{ Extraction Method: Principal Component Analysis } \\
\hline Expl. Var. & 4,573 & 1,000 & 1,000 \\
\hline Expl. /Tot. & 1,000 & Sum & Sum \\
\hline
\end{tabular}




\section{Appendix D}

Detailed Figures and Tables

\section{Figure A 1}

Strengths and Weaknesses of 66 Countries in 2009/2010

\begin{tabular}{|c|c|c|c|c|c|c|c|}
\hline Country/Region & Rank & 1. Economic Activity & $\begin{array}{l}\text { 2. Real Estate } \\
\text { Investment } \\
\text { Opportunities }\end{array}$ & $\begin{array}{l}\text { 3. Depth of Capita } \\
\text { Market }\end{array}$ & $\begin{array}{c}\text { 4. Investor } \\
\text { Protection and } \\
\text { Legal Framework }\end{array}$ & $\begin{array}{l}\text { 5. Administrative } \\
\text { Burdens and } \\
\text { Regulatory } \\
\text { Limitations }\end{array}$ & $\begin{array}{l}\text { 6. Socio-Cultural } \\
\text { and Political } \\
\text { Environment }\end{array}$ \\
\hline United States & 1 & 100,0 & 100,0 & 100,0 & 100,0 & 100,0 & 100,0 \\
\hline United Kingdom & 2 & 90,2 & 73,6 & 84,9 & 105,3 & 111,5 & 106,4 \\
\hline Hong Kong & 3 & 85,5 & 66,7 & 85,2 & 111,4 & 116,4 & 109,3 \\
\hline Australia & 4 & 91,6 & 65,0 & 81,2 & 94,5 & 104,7 & 116,5 \\
\hline Canada & 5 & 90,3 & 60,0 & 81,3 & 100,9 & 105,6 & 117,5 \\
\hline Singapore & 6 & 78,5 & 62,3 & 73,4 & 112,1 & 124,7 & 109,8 \\
\hline Germany & 7 & 88,7 & 77,0 & 67,3 & 87,7 & 113,2 & 115,3 \\
\hline Japan & 8 & 84,5 & 75,9 & 79,2 & 87,9 & 96,1 & 100,6 \\
\hline Netherlands & 9 & 90,6 & 63,2 & 67,4 & 87,6 & 111,5 & 115,6 \\
\hline Sweden & 10 & 83,4 & 56,6 & 66,3 & 88,7 & 116,1 & 123,5 \\
\hline France & 11 & 88,2 & 75,4 & 74,8 & 74,9 & 95,3 & 105,1 \\
\hline Switzerland & 12 & 91,6 & 53,0 & 74,7 & 64,4 & 115,7 & 125,3 \\
\hline Republic of Korea & 13 & 90,3 & 66,7 & 68,8 & 73,1 & 110,4 & 87,0 \\
\hline Denmark & 14 & 79,8 & 54,2 & 53,6 & 102,9 & 114,9 & 126,9 \\
\hline Spain & 15 & 79,4 & 64,9 & 70,9 & 75,4 & 99,8 & 95,1 \\
\hline Belgium & 16 & 83,2 & 56,1 & 52,3 & 92,1 & 108,5 & 110,2 \\
\hline Austria & 17 & 87,9 & 53,5 & 44,2 & 85,0 & 106,6 & 120,5 \\
\hline Norway & 18 & 92,0 & 45,0 & 39,9 & 95,4 & 106,1 & 122,8 \\
\hline Finland & 19 & 81,5 & 47,0 & 37,8 & 93,6 & 115,0 & 128,3 \\
\hline New Zealand & 20 & 75,0 & 39,0 & 42,4 & 112,6 & 104,4 & 125,2 \\
\hline Israel & 21 & 84,4 & 48,5 & 55,1 & 94,7 & 89,4 & 79,5 \\
\hline Italy & 22 & 73,7 & 62,3 & 62,3 & 56,7 & 96,8 & 69,8 \\
\hline Taiwan & 23 & 77,5 & 60,2 & 44,0 & 68,9 & 103,0 & 81,8 \\
\hline Malaysia & 24 & 79,7 & 47,6 & 56,5 & 77,5 & 81,8 & 65,9 \\
\hline Ireland & 25 & 67,8 & 47,8 & 22,6 & 107,4 & 121,2 & 115,8 \\
\hline Poland & 26 & 76,9 & 44,5 & 50,2 & 70,1 & 88,3 & 77,5 \\
\hline Greece & 27 & 76,5 & 54,8 & 50,8 & 49,0 & 87,9 & 79,4 \\
\hline Portugal & 28 & 68,4 & 54,6 & 26,2 & 67,9 & 103,5 & 98,2 \\
\hline Chile & 29 & 73,5 & 43,8 & 24,9 & 78,3 & 91,3 & 96,0 \\
\hline Mexico & 30 & 64,6 & 64,6 & 39,3 & 52,6 & 97,1 & 43,8 \\
\hline Luxembourg & 31 & 75,9 & 34,3 & 18,0 & 85,3 & 109,7 & 125,2 \\
\hline China & 32 & 91,8 & 73,8 & 37,5 & 41,9 & 69,2 & 42,3 \\
\hline United Arab Emirates & 33 & 92,5 & 37,7 & 29,0 & 53,0 & 80,6 & 88,6 \\
\hline South Africa & 34 & 62,9 & 53,7 & 44,6 & 73,0 & 84,9 & 35,4 \\
\hline Romania & 35 & 67,0 & 35,1 & 36,2 & 59,5 & 102,8 & 66,9 \\
\hline Brazil & 36 & 78,1 & 68,8 & 50,3 & 42,3 & 53,6 & 52,1 \\
\hline India & 37 & 60,6 & 60,9 & 68,5 & 62,2 & 49,6 & 42,4 \\
\hline Thailand & 38 & 70,0 & 42,3 & 41,0 & 56,9 & 80,2 & 51,3 \\
\hline Turkey & 39 & 66,3 & 62,2 & 23,6 & 55,8 & 93,8 & 56,4 \\
\hline Czech Republic & 40 & 78,7 & 46,3 & 17,3 & 71,7 & 85,5 & 89,2 \\
\hline Saudi Arabia & 41 & 81,2 & 47,7 & 21,4 & 58,8 & 107,4 & 50,8 \\
\hline Hungary & 42 & 58,3 & 46,2 & 17,1 & 71,0 & 104,5 & 86,1 \\
\hline Argentina & 43 & 67,4 & 46,9 & 32,6 & 32,7 & 80,3 & 54,5 \\
\hline Egypt & 44 & 55,3 & 44,0 & 32,8 & 46,1 & 84,5 & 38,0 \\
\hline Indonesia & 45 & 67,4 & 50,2 & 35,1 & 38,3 & 64,6 & 38,6 \\
\hline Morocco & 46 & 55,9 & 41,8 & 31,7 & 31,8 & 90,3 & 48,8 \\
\hline Croatia & 47 & 62,2 & 36,2 & 16,7 & 50,8 & 92,5 & 77,2 \\
\hline Russian Federation & 48 & 70,2 & 53,8 & 57,3 & 34,4 & 39,3 & 30,6 \\
\hline Kuwait & 49 & 81,9 & 22,5 & 21,6 & 61,7 & 65,9 & 78,8 \\
\hline Slovenia & 50 & 71,1 & 33,7 & 10,3 & 71,2 & 82,6 & 100,0 \\
\hline Slovakia & 51 & 75,9 & 38,2 & 7,3 & 69,6 & 106,5 & 85,9 \\
\hline Lithuania & 52 & 56,7 & 27,1 & 12,4 & 64,9 & 116,6 & 84,1 \\
\hline Oman & 53 & 67,7 & 27,7 & 11,9 & 58,0 & 84,6 & 81,9 \\
\hline Bulgaria & 54 & 58,1 & 30,0 & 14,5 & 52,0 & 99,2 & 55,1 \\
\hline Philippines & 55 & 56,9 & 46,6 & 32,9 & 35,2 & 49,1 & 36,2 \\
\hline Peru & 56 & 64,3 & 41,6 & 8,2 & 55,4 & 95,2 & 48,2 \\
\hline Estonia & 57 & 38,6 & 26,0 & 7,8 & 81,0 & 114,8 & 98,9 \\
\hline Colombia & 58 & 62,6 & 48,8 & 8,6 & 39,3 & 92,4 & 25,3 \\
\hline Latvia & 59 & 30,1 & 23,8 & 6,5 & 77,0 & 107,3 & 86,8 \\
\hline Vietnam & 60 & 49,8 & 31,0 & 22,0 & 20,6 & 67,9 & 33,0 \\
\hline Uruguay & 61 & 56,4 & 33,5 & 3,6 & 56,6 & 82,4 & 96,3 \\
\hline Ukraine & 62 & 50,8 & 36,4 & 12,6 & 46,5 & 45,3 & 43,9 \\
\hline Nigeria & 63 & 53,3 & 30,4 & 10,9 & 39,8 & 40,9 & 7,1 \\
\hline Kenya & 64 & 12,6 & 19,4 & 9,0 & 43,2 & 57,9 & 19,8 \\
\hline Paraguay & 65 & 20,0 & 15,2 & 3,2 & 26,8 & 93,1 & 29,2 \\
\hline Venezuela & 66 & 28,0 & 22,8 & 5,9 & 3,2 & 24,9 & 13,9 \\
\hline
\end{tabular}

Benchmark: United States $=100$ points. 